\title{
TRADITIONAL AND EMERGING GEOCHEMICAL PROXIES IN FORAMINIFERA
}

\author{
Miriam E. Katz ${ }^{1,6}$, Benjamin S. CrameR ${ }^{2}$, Allison Franzese ${ }^{3}$, Bärbel Hönisch ${ }^{4}$, Kenneth G. Miller $^{5}$, \\ YAIR ROSENTHAL ${ }^{3,5}$ AND JAMES D. WRIGHT ${ }^{5}$
}

\section{ABSTRACT}

Geochemical analyses of the carbonate tests calcified by foraminifera have provided much of the foundation for reconstructions of past ocean and climate conditions, and for chemostratigraphy. In particular, reconstructions of climate history (including temperature, salinity, and ice volume), ocean paleocirculation patterns, the carbon cycle, paleoproductivity, marine carbonate chemistry, and chemostratigraphy have relied on measurements of isotopic and trace element composition of foraminiferal calcium carbonate, and variations in these geochemical records through time and space. Substantial work has been done on details of traditional proxies (e.g., $\delta^{18} \mathrm{O}, \delta^{13} \mathrm{C}$ ) and on emerging proxies (e.g., $\left.\delta^{11} \mathrm{~B}, \varepsilon_{\mathrm{Nd}}\right)$ in recent years; hence, a new overview of these proxies provides a timely reference and educational tool. We review the geochemical proxies that utilize foraminiferal carbonate tests, including potential uses of the proxies for reconstructions through time: $\delta^{18} \mathrm{O}, \delta^{13} \mathrm{C}$, trace elements (Mg, Cd, Ba, Zn, B, U), ${ }^{87} \mathrm{Sr} /{ }^{86} \mathrm{Sr}, \delta^{26} \mathrm{Mg}, \delta^{11} \mathrm{~B}$, and $\varepsilon_{\mathrm{Nd}}$. Both planktic and benthic foraminifera are included; planktic foraminifera provide information on the upper few hundred meters of the surface ocean, whereas benthic foraminifera provide information on conditions at the seafloor and in shallow porewaters, from shallow seas to deep ocean basins.

\section{INTRODUCTION}

The development of myriad geochemical proxies and refinement of analytical techniques applied to calcareous foraminifera has exploded in recent decades, and has greatly enhanced our abilities to reconstruct a wide spectrum of climate and oceanographic parameters from the geologic record. Recent advances in the uses and understanding of both traditional proxies (e.g., $\delta^{18} \mathrm{O}, \delta^{13} \mathrm{C}$ ) and emerging proxies (e.g., $\delta^{11} \mathrm{~B}, \varepsilon_{\mathrm{Nd}}$ ) warrant a new review that encompasses multiple geochemical proxies in foraminifera, from fundamentals to recent developments. Here, we review these proxies, including systematics and applications (Table 1). This paper provides a timely reference and educational tool, including overview, detail, and citations that can be pursued for further investigation. It is written for a wide audience, from students who need a broad-based background to specialists interested in exploring different proxies. We focus on open-ocean and deep-ocean applica-

\footnotetext{
${ }^{1}$ Dept. of Earth and Environmental Sciences, Rensselaer Polytechnic Institute, Troy, NY 12180 USA.

${ }^{2}$ Theiss Research, Eugene, OR USA.

${ }^{3}$ Inst. of Marine \& Coastal Sci., Rutgers University, 71 Dudley Rd. New Brunswick, NJ 08901 USA.

${ }^{4}$ Lamont-Doherty Earth Observatory of Columbia University, Rt. 9W, Palisades, NY 10964 USA.

${ }^{5}$ Dept. of Earth and Planetary Sciences, Rutgers University, Piscataway, NJ 08854 USA.

${ }^{6}$ Correspondence author: E-mail: katzm@rpi.edu
}

tions, and note that these proxies can also be applied to more restricted environments such as coastlines and methane seeps.

A combination of parameters such as water chemistry, biological processes, and habitat preferences ultimately determine the geochemical signatures recorded in foraminiferal calcite. Understanding the impact of these factors on foraminiferal carbonate chemistry is critical to data interpretations. Therefore, we begin this review with a summary of these parameters.

\section{BENTHIC FORAMINIFERA}

Living benthic foraminifera are most abundant in the upper $1 \mathrm{~cm}$ of sediment, including the sediment surface, which is referred to as an epifaunal microhabitat. Benthic foraminifera may also live deeper in the sediment (most abundant in the upper few $\mathrm{cm}$; occasionally as deep as $\sim 20 \mathrm{~cm}$ ), which is referred to as an infaunal microhabitat (e.g., Corliss, 1985; Gooday, 1986; Rathburn and Corliss, 1994; Jorissen and others, 1995; de Steiger and others, 1998). Benthic foraminifera may also reside in elevated habitats, such as attached to sea grass and coral, or within phytodetritus that accumulates on the seafloor. Benthic foraminifera may change microhabitat depth slightly (usually in response to food abundance or oxygen availability), or burrow up/down during a life cycle (Bender and others, 1985; Jorissen and others, 1992). Because of differences in microhabitats, the chemistry of epifaunal tests is thought to record water properties at the seafloor, whereas the chemistry of infaunal tests is thought to record porewater properties. Epifaunal genera most often used in geochemical analyses are Cibicidoides, Nuttallides, Oridorsalis, and Planulina. The most commonly used infaunal genus is Uvigerina.

Even before the widespread use of geochemical techniques, foraminiferal faunal distributions were used to reconstruct paleoenvironmental conditions and paleocirculation changes. This technique has been employed with varying degrees of success with benthic foraminifera, in large part because multiple environmental factors can influence the distributions of different species. The primary controls on these distributions are food availability and/or oxygen concentration, and hence, the abundances of certain benthic foraminifera have been used to reconstruct past food and oxygen availability (e.g. Lutze, 1978; Schnitker, 1979; Miller and Lohmann, 1982; Katz and Miller, 1993; Gooday, 1994; Rathburn and Corliss, 1994; Smart and others, 1994; Jorissen and others, 1995; Thomas and Gooday, 1996; Bernhard and others, 1997; Schmiedl and others, 1997; Cannariato and Kennett, 1999; Gooday and Rathburn, 1999; van der Zwaan and others, 1999; Kaiho, 1999.; Schmiedl and others, 2000; Morigi and others, 2001).

Streeter (1973) and Schnitker (1974) linked benthic foraminiferal species occurrences to physiochemical proper- 
TABLE 1. Geochemical proxies applied to calcareous foraminifera.

\begin{tabular}{|c|c|c|c|c|c|c|c|c|c|c|c|c|}
\hline & $\delta^{18} \mathrm{O}$ & $\delta^{13} \mathrm{C}$ & $\delta^{11} \mathrm{~B}$ & ${ }^{87} \mathrm{Sr} /{ }^{86} \mathrm{Sr}$ & $\mathrm{Mg} / \mathrm{Ca}$ & $\mathrm{Cd} / \mathrm{Ca}$ & $\mathrm{Ba} / \mathrm{Ca}$ & $\mathrm{Zn} / \mathrm{Ca}$ & $\mathrm{B} / \mathrm{Ca}$ & $\mathrm{U} / \mathrm{Ca}$ & $\delta^{11} \mathrm{Nd}$ & $\delta^{26} \mathrm{Mg}$ \\
\hline ice volume & $\mathrm{x}$ & & & & & & & & & & & \\
\hline temperature & $\mathrm{x}$ & & & & $\mathrm{x}$ & & & & & & & \\
\hline circulation & & $\mathrm{x}$ & & & & $\mathrm{x}$ & $\mathrm{x}$ & $\mathrm{x}$ & & & $\mathrm{x}$ & \\
\hline productivity & & $\mathrm{x}$ & & & & & & & & & & \\
\hline carbonate saturation & & & $x$ & & & & & $\mathrm{x}$ & $\mathrm{x}$ & $\mathrm{x}$ & & \\
\hline $\begin{array}{l}\text { chemostratigraphy } \\
\text { seawater }[\mathrm{Mg}]\end{array}$ & $\mathrm{x}$ & $\mathrm{x}$ & & $\mathrm{x}$ & & & & & & & & $\mathrm{x}$ \\
\hline
\end{tabular}

ties of different water masses in the Atlantic; this type of association has been utilized to reconstruct changes in water-mass structure and circulation through time (e.g., Lohmann, 1978; Corliss, 1979b, a; Schnitker, 1979; Streeter and Shackelton, 1979; Murray, 1984; Boersma, 1985; Miller and Katz, 1987; Mackensen and others, 1993a; Murray, 1995; Schmiedl and Mackensen, 1997; Gooday, 2003; Katz and others, 2003b). The increasing use of isotope and trace element geochemical proxies has greatly enhanced the utility of benthic foraminifera in these types of studies.

\section{PlankTiC Foraminifera}

The distribution of planktic foraminiferal species in the modern ocean tends to correlate with temperature, with certain species more abundant in warm waters, while others are more abundant in cooler waters (Bradshaw, 1959; Bè and Tolderland, 1971; Imbrie and Kipp, 1971; Bè, 1977; Rutherford and others, 1999). As with other ecosystems, the greatest diversity in the planktic foraminiferal assemblages is in the tropics. Diversity decreases towards the poles with polar assemblages dominated by Neogloboquadrina pachyderma (Ehrenberg). The CLIMAP (Climate: LongRange Investigation, Mapping, and Prediction) project exploited this relationship, producing the first comprehensive syntheses of sea surface temperatures (SSTs) for the last glacial maximum (CLIMAP, 1976, 1981). Detailed mathematical relationships between planktic foraminifera and SSTs were developed further in subsequent studies (e.g., Mix and others, 1986; Mix and others, 1999). Additional studies have used planktic foraminiferal assemblages to infer relative temperature changes during the Neogene (e.g., Thunell and Belyea, 1982; Kennett and others, 1985; Wright and Thunell, 1988). Only relative SSTs can be estimated for Miocene and older assemblages because many of the species comprising these assemblages are extinct.

The wide distribution of planktic foraminifera in surface waters and the calcitic mineralogy of their tests make them an attractive group for geochemical analysis. However, while planktic foraminiferal thanatocoenoses (fossils in an assemblage that may or may not have lived at the same time) can be related to the overlying surface-water conditions, large physical and chemical gradients exist in the upper water column, requiring knowledge of a species' preferred depth habitat and/or seasonal biases to make more informed interpretations of geochemical data (e.g., Fairbanks and Wiebe, 1980; Fairbanks and others, 1980). In many locations, this seasonal and/or vertical variability can be greater than the long-term climate signals to be ascertained.
Planktic foraminiferal assemblages reflect food availability in addition to water temperatures, which is a factor in determining different water depth habitats of different species (Berger and others, 1978; Fairbanks and others, 1982; Curry and others, 1983; Thunell and Reynolds, 1984; Ravelo and Fairbanks, 1992). Taxa are characterized as shallow, intermediate/thermocline, or deep dwellers, and use two feeding strategies to exploit the physiochemical differences in each niche. The surface mixed layer tends to have lower nutrient levels because most of the nutrients are quickly scavenged. As a result, shallow assemblages are dominated by symbiont-bearing species such as Globigerinoides sacculifer (Brady) and Globigerinoides ruber (d'Orbigny). These species adopt a dual feeding strategy such that when food is available (e.g., copepods), they capture prey (Anderson and Bè, 1976). The photosynthetic activity of the symbiotic algae within the foraminiferal protoplasm provides supplemental food for the host (Anderson and Bè, 1976). Planktic foraminifera with symbionts are predominantly spinose and maintain a relatively shallow position in the water column, presumably to maximize photosynthesis (Fairbanks and others, 1980; Bè and others, 1982; Fairbanks and others, 1982).

The majority of non-spinose planktic foraminifera rely on food within the water column. One of the most important hydrographic controls on the availability of food is the depth and intensity of the seasonal thermocline. This steep change in temperature in the upper water column creates a steep density gradient that concentrates food particles falling from the surface. When the thermocline occurs in the euphotic zone (i.e., the upper $\sim 100 \mathrm{~m}$ of the water column), both high light intensity and high nutrient levels support high levels of primary production. The resulting phytoplankton biomass provides a food-rich environment that can support a large zooplankton biomass, including planktic foraminifera. The richest diversity and abundance of planktic foraminifera occurs when the thermocline is in the euphotic zone (Fairbanks and Wiebe, 1980; Ortner and others, 1980).

\section{STABLE ISOTOPES $\left(\delta^{18} \mathrm{O}\right.$ AND $\left.\delta^{13} \mathrm{C}\right)$}

\section{OXYGEN IsOTOPES $\left(\delta^{18} \mathrm{O}\right)$}

The deviation from a standard of the ratio of isotopes of oxygen $\left({ }^{18} \mathrm{O} /{ }^{16} \mathrm{O}\right)$ can be measured in the $\mathrm{CaCO}_{3}$ tests of planktic and benthic foraminifera, and is reported in " $\delta$ " notation, calculated as follows: 


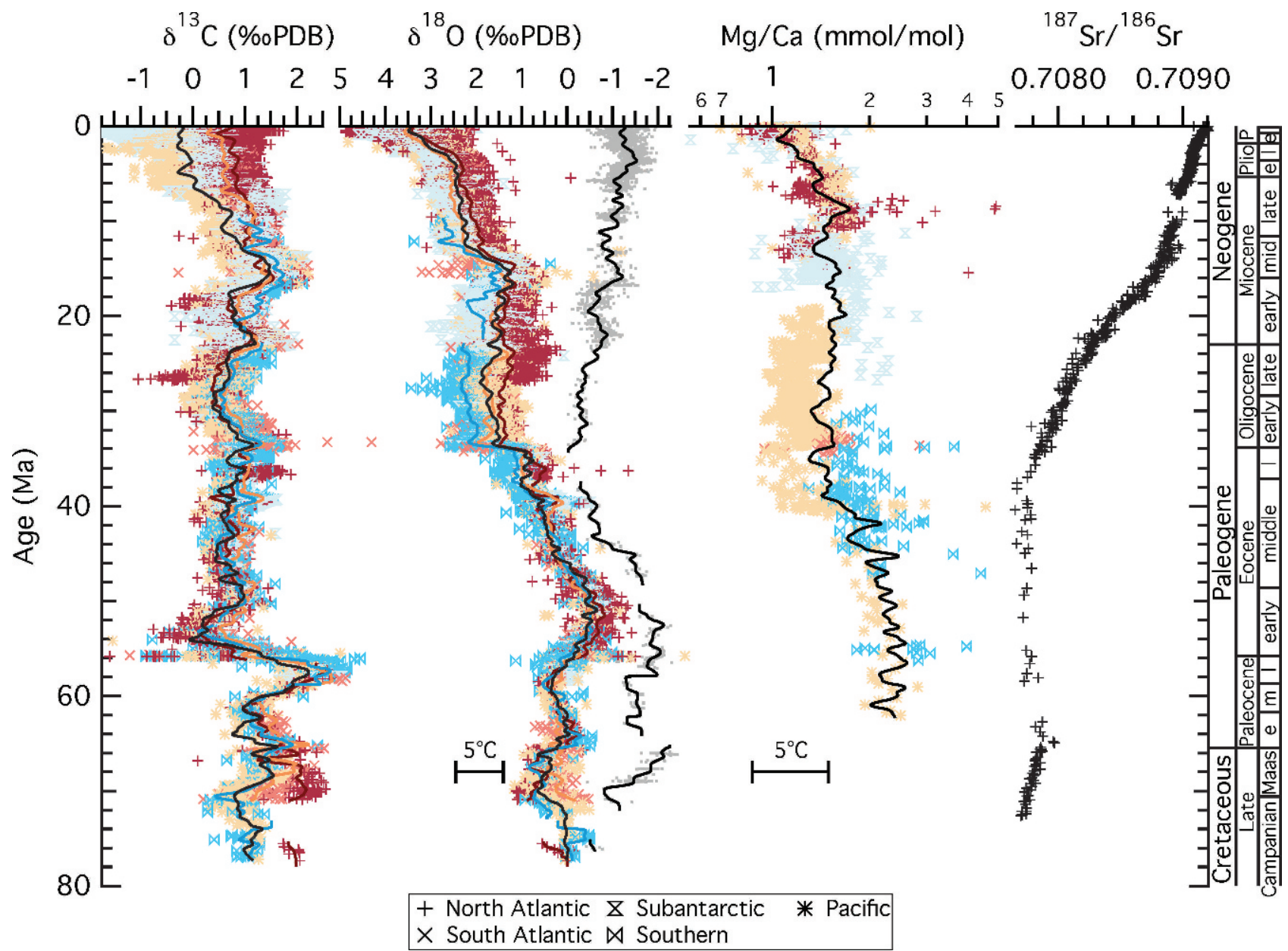

FIGURE 1. Compilations of geochemical proxies measured on foraminifera. (a) benthic foraminiferal $\delta^{13} \mathrm{C}$; (b) benthic (colors) and planktic (gray with black trend line) foraminiferal $\delta^{18} \mathrm{O}$; (c) benthic foraminiferal $\mathrm{Mg} / \mathrm{Ca}$, and (d) foraminiferal ${ }^{87} \mathrm{Sr} /{ }^{86} \mathrm{Sr}$. Separate trends are shown to highlight interbasinal gradients in the stable isotope records (black: tropical Pacific; dark red: North/Equatorial Atlantic; orange: South Atlantic/Subantarctic; blue: high latitude Southern Ocean). The equivalent in $\delta^{18} \mathrm{O}$ and $\mathrm{Mg} / \mathrm{Ca}$ of a $5^{\circ} \mathrm{C}$ temperature change is based on calibrations from Bemis and others (1998) and Lear and others (2002); note that the temperature signal in both records is complicated by variations in seawater chemistry, as discussed in the text. Benthic foraminiferal stable isotope compilations and trends are from Cramer and others (2009); planktic foraminiferal stable isotope compilation is from multiple sources (Wright 2001; Huber and others, 2002; MacLeod and others, 2005); Mg/Ca compilation includes data from multiple sources (Lear and others, 2000; Billups and Schrag, 2002, 2003; Lear and others, 2003; Lear and others, 2004; Dutton and others, 2005; Shevenell and others, 2008); ${ }^{87} \mathrm{Sr} /{ }^{86} \mathrm{Sr}$ compilation includes data from multiple sources (DePaolo and Ingram, 1985; Hess and others, 1986; McKenzie and others, 1988; Miller and others, 1988; Hodell and others, 1991; Miller and others, 1991a; Hodell and Woodruff, 1994; Oslick and others, 1994; Farrell and others, 1995; Reilly and others, 2002; Hodell and others, 2007). The procedure used to calculate the benthic foraminiferal $\delta^{18} \mathrm{O}$ trend lines is described in Cramer and others (2009); the same procedure was used to calculate the planktic $\delta^{18} \mathrm{O}$ and benthic $\mathrm{Mg} / \mathrm{Ca}$ trend lines shown here.

$$
\begin{aligned}
\delta^{18} \mathrm{O}_{\text {sample }}= & 1000 \times\left[\left({ }^{18} \mathrm{O} /{ }^{16} \mathrm{O}\right)_{\text {sample }}-\left({ }^{18} \mathrm{O} /{ }^{16} \mathrm{O}\right)_{\text {standard }}\right] / \\
& \left({ }^{18} \mathrm{O} /{ }^{16} \mathrm{O}\right)_{\text {standard }}
\end{aligned}
$$

The oxygen isotopic composition of the foraminiferal test reflects the $\delta^{18} \mathrm{O}$ of the seawater $\left(\delta_{\mathrm{w}}\right)$ in which the foraminifera calcify, as well as the temperature-dependent fractionation during the calcification process. In turn, $\delta_{\mathrm{w}}$ is a function of: 1) global ice volume; and 2) local/regional river-water input and evaporation/precipitation patterns for shelf and surface waters, especially towards high latitudes. This is because the fractionation during evaporation $\left(\mathrm{H}_{2}{ }^{16} \mathrm{O}\right.$ is more readily evaporated) produces ${ }^{16} \mathrm{O}$-enriched precipitation over land, resulting in (1) ${ }^{16} \mathrm{O}$-enriched glacial ice (and to a lesser extent, lakes and groundwater) sequestered on land; and (2) ${ }^{16} \mathrm{O}$-enriched river runoff to the oceans. $\delta^{18} \mathrm{O}$, along with $\delta^{13} \mathrm{C}$ measured in the same analysis, was the first geochemical proxy routinely measured in foraminifera (Fig. 1). It remains a central tool for paleoceanographic reconstructions, being widely used as a paleothermometer, ice-volume indicator, and sea-level indicator. While several paleotemperature equations have been developed for planktic (e.g., Bemis and others, 1998) and benthic (e.g., Shackleton and Kennett, 1975) foraminifera, they all are based on the original temperature equation proposed by Epstein and others (1953):

$$
\mathrm{T}=16.5-4.3 \times\left(\delta^{18} \mathrm{O}_{\text {calcite }}-\delta_{\mathrm{w}}\right)+0.14 \times\left(\delta^{18} \mathrm{O}_{\text {calcite }}-\delta_{\mathrm{w}}\right)^{2}
$$

where $\mathrm{T}$ is the temperature $\left({ }^{\circ} \mathrm{C}\right), \delta_{\mathrm{w}}$ is the oxygen isotope value of the water in which the organism lived, and $\delta^{18} \mathrm{O}_{\text {calcite }}$ is the oxygen isotope value of foraminiferal calcite 


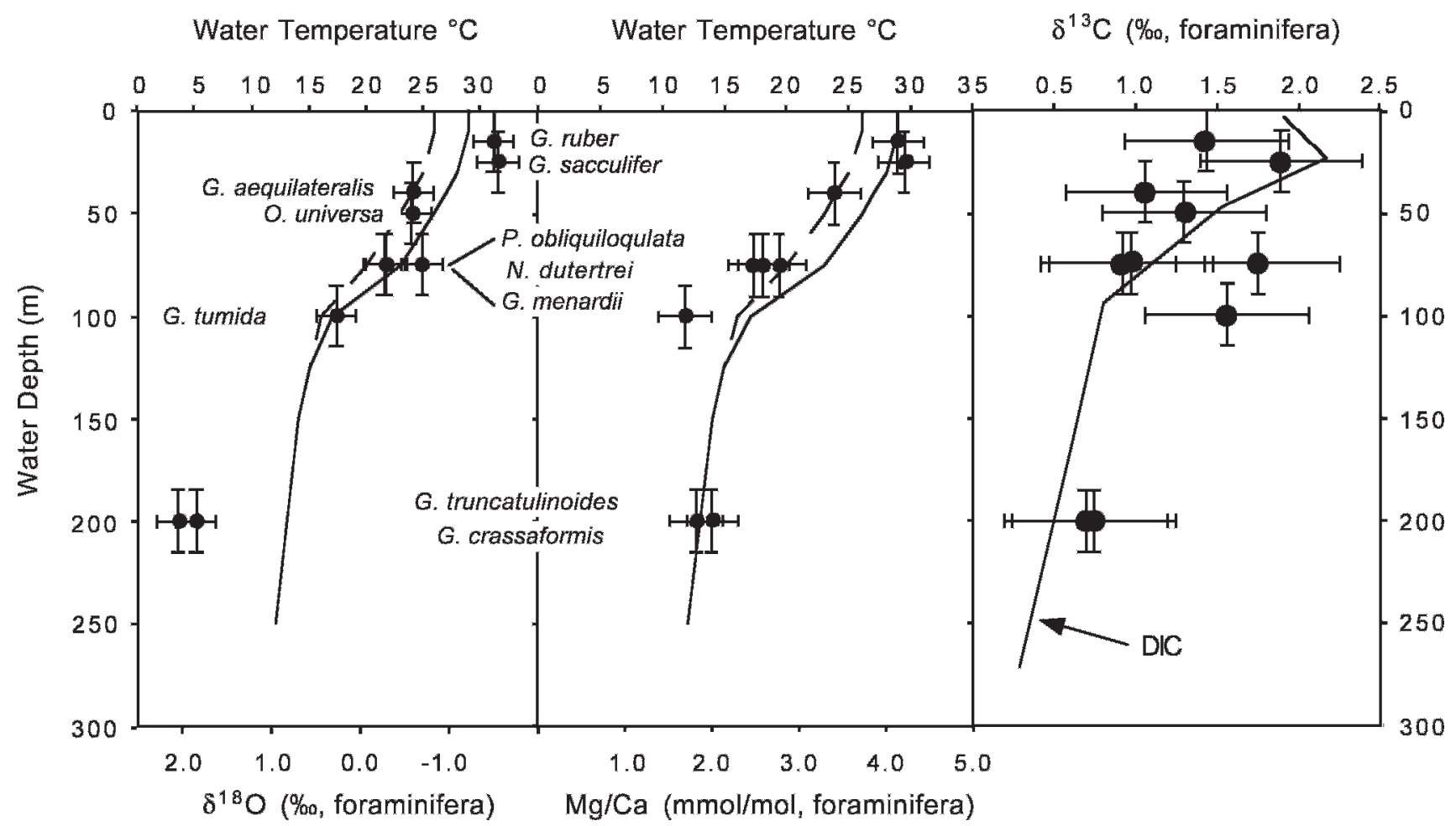

FIGURE 2. Planktic foraminiferal geochemistry reflects depth habitat, varying with changes in seawater properties. Planktic foraminiferal data are from core-top samples, Sierra Leone Rise EN66 38GGC, including $\delta^{18} \mathrm{O}$ and $\mathrm{Mg} / \mathrm{Ca}$ (Rosenthal and Boyle, 1993) and $\delta^{13} \mathrm{C}$ (Rosenthal, unpublished data). Seawater seasonal temperature range (indicated by solid and dashed lines) and $\delta^{13} \mathrm{C}$ of DIC are from nearby GEOSECS station 113 . Error bars indicate estimated range in calcification depth and water properties. Species names are displayed at approximate calcification depth.

measured in a mass spectrometer. A change in the $\delta_{\mathrm{w}}$ term will cause an equal change in the measured $\delta^{18} \mathrm{O}_{\text {calcite }}$ value, whereas an inverse relationship exists between $\delta^{18} \mathrm{O}_{\text {calcite }}$ and temperature such that for every $1{ }^{\circ} \mathrm{C}$ increase, there is a $\sim 0.23 \%$ decrease in the measured $\delta^{18} \mathrm{O}_{\text {calcite }}$ value. These relationships allow us to interpret the $\delta^{18} \mathrm{O}$ values in calcitesecreting organisms, including foraminifera.

Variations in the amount of water stored on land through time, usually in the form of ice, can have a significant effect on the mean ocean $\delta_{\mathrm{w}}$ value, and hence, on the marine $\delta^{18} \mathrm{O}_{\text {calcite }}$ record. During interglacial periods, most highlatitude precipitation returns to the oceans via summer ice and snow melt. During glacials, a larger fraction of ${ }^{16} \mathrm{O}-$ enriched snow and ice persists through cooler summers and accumulates into large continental ice sheets. The difference between ice sheet $(-35$ to $-40 \%)$ and mean ocean $(\sim 0 \%)$ $\delta^{18} \mathrm{O}$ values is large, so fluctuations in ice-sheet size alter mean oceanic $\delta_{\mathrm{w}}$ values.

For example, water stored in continental ice sheets during the last glacial maximum lowered global sea level by $\sim 120 \pm 5 \mathrm{~m}$, removed $\sim 3 \%$ of the ocean's water volume, and resulted in a mean ocean $\delta_{\mathrm{w}}$ value that was $1.2 \%$ higher than it is today. Therefore, there is a relationship between $\delta_{\mathrm{w}}$ and sea level, with an empirical calibration of $0.10-0.12 \% / 10 \mathrm{~m}$, likely varying through time because of varying ice sheet $\delta^{18} \mathrm{O}$ (Fairbanks and Matthews, 1978; Pekar and others, 2002; Miller and others, 2005; Katz and others, 2008; Miller and others, 2008).
Related to this, benthic foraminiferal $\delta^{18} \mathrm{O}$ records can be used to reconstruct global ice-volume changes and past ocean temperature at the seafloor. Seafloor temperature reconstructions for times when large continental ice sheets existed must separate the temperature signal from the $\delta_{\mathrm{w}}$ signal recorded in foraminiferal $\delta^{18} \mathrm{O}$. The current approach to unravelling these two signals is to measure $\delta^{18} \mathrm{O}$ and $\mathrm{Mg} / \mathrm{Ca}$ in the same samples (see "Foraminiferal $\mathrm{Mg} / \mathrm{Ca}$ paleothermometry" below). Glacial-interglacial deep-sea temperature changes are relatively small compared to SST changes at most latitudes; therefore, the amplitude in glacial-interglacial planktic foraminiferal $\delta^{18} \mathrm{O}$ may be larger than the benthic foraminiferal $\delta^{18} \mathrm{O}$ signal.

In addition to reconstructing past ocean temperature at the seafloor and global ice-volume changes, benthic foraminiferal $\delta^{18} \mathrm{O}$ records can be used to reconstruct past deepwater source regions. The deep-ocean $\delta^{18} \mathrm{O}$ of benthic foraminifera approximates the high-latitude surface-water conditions where the major deepwater masses originate. Interbasinal gradients in benthic foraminiferal $\delta^{18} \mathrm{O}$ values (Fig. 1) can be a useful indicator of differentiation between deepwater source regions, and therefore of large-scale changes in the mode of ocean overturning (Cramer and others, 2009). Comparison of low-latitude planktic with high-latitude benthic foraminiferal $\delta^{18} \mathrm{O}$ records provides the means to assess temperature gradients, both equator-topole and surface-to-deep (Fig. 1), providing the means to reconstruct the planetary temperature gradients and poleward heat transport that are a primary driver of climate 
change (see "Foraminiferal $\mathrm{Mg} / \mathrm{Ca}$ paleothermometry" below).

Planktic foraminiferal $\delta^{18} \mathrm{O}$ can be a good proxy for SSTs if several issues are taken into account. Different species from the same sediment sample may show $\delta^{18} \mathrm{O}$ offsets of as much as $1.5 \%$. This offset is attributed in part to speciesspecific vital effects (i.e., species-specific metabolic variation in isotopic fractionation), but some offset results from differences in seasonal temperatures or depth habitats of different species (Fig. 2), which may vary from region to region (e.g., Bè and others, 1966; Fairbanks and Wiebe, 1980; Fairbanks and others, 1980; Fairbanks and others, 1982; Curry and Crowley, 1987; Ravelo and Fairbanks, 1992; Spero and others, 2003). During the planktic foraminiferal life cycle, vertical migration through the water column with a surface-to-deep temperature gradient may result in $\delta^{18} \mathrm{O}$ differences between inner and outer test chambers, depending on the depth of calcification. Because differences in seasonal surface-water temperatures or different depth habitats of various species can affect planktic foraminiferal $\delta^{18} \mathrm{O}$, multi-species analyses may allow reconstructions of temperature gradients within the upper part of the surface ocean (e.g., Bè and others, 1966; Fairbanks and others, 1980; Fairbanks and others, 1982; Ravelo and Fairbanks, 1992; Spero and others, 2003).

Changes during the life cycle of some planktic foraminiferal species may affect specimens' $\delta^{18} \mathrm{O}$ values. Some planktic foraminifera secrete a calcite layer towards the end of the life cycle, prior to gamete release (e.g., Bè and others, 1966; Fairbanks and others, 1980). As part of the gametogenesis cycle, many of the surface-dwelling planktic foraminifera will shed their spines and sink through the water column. Even while they are reproducing, some shell mass is added at depth; this can change the overall shell chemistry that was originally acquired in shallower water. This is a concern when making measurements in the tropics, where SSTs can be 10 to $15^{\circ} \mathrm{C}$ warmer than in the thermocline waters through which the foraminifera sink.

In the mid- to high-latitudes, the largest temperature variations occur at the surface and produce a seasonal succession of planktic foraminifera as SSTs warm and cool (e.g., Reynolds and Thunell, 1985, 1986; Deuser, 1987; Sautter and Thunell, 1989). Subsurface vertical temperature changes are small. During winter, nearly isothermal conditions extend downward from the surface through the depth range of the planktic foraminiferal habitat. Hence, the largest temperature variations are seasonal and are usually restricted to the upper $50 \mathrm{~m}$. Phytoplankton, and hence zooplankton, bloom when light and nutrients exceed minimum threshold levels in the surface water. This event is diachronous regionally because it occurs progressively later at higher latitudes. Sediment traps provide a record of the planktic foraminiferal flux throughout the year (e.g., Reynolds and Thunell, 1985). In mid- to high-latitude regions, the flux of most planktic foraminifera to the seafloor is weighted towards a very short annual interval, and therefore may provide only seasonal information (e.g., Reynolds and Thunell, 1985, 1986; Donner and Wefer, 1994).

The $\delta^{18} \mathrm{O}$ offsets among planktic foraminiferal species can provide the means to reconstruct surface-water structure and seasonal temperature changes (Fig. 2). However, the offsets also may introduce error into paleoceanographic reconstructions through time. Nonetheless, careful correction for interspecies isotopic differences provides the opportunity to reconstruct water-column structure and paleoceanographic changes.

\section{Diagenesis and $\delta^{18} \mathrm{O}$}

Post-depositional diagenesis can affect foraminiferal $\delta^{18} \mathrm{O}$ values. Deep-burial diagenesis $(>\sim 500 \mathrm{~m})$ tends to decrease $\delta^{18} \mathrm{O}$ values because fossil foraminiferal tests may recalcify at equilibrium with sediment temperatures that are higher than at the seafloor, due to the geothermal gradient. Recent work indicates that shallow-burial diagenesis might alter planktic foraminiferal $\delta^{18} \mathrm{O}$ values by overprinting a cool deepwater signal on warm surface-water planktic foraminiferal calcite (Pearson and others, 2001). This diagenesis may occur when calcium carbonate precipitates on the foraminiferal tests in the sediments in cold bottom waters. Benthic foraminifera would not be adversely affected by this process because they calcify in the same cold bottom waters in which they are buried. Perhaps the most effective strategy is to avoid diagenetic and recrystallization complications by analyzing foraminifera preserved in clay-rich sediments that are better insulated from potential porewater diagenesis, making them more suitable for geochemical analyses (Pearson and others, 2001). Foraminifera preserved in clay-rich sediments appear to retain their original structures and geochemical signatures (Pearson and others, 2001; Sexton and others, 2006).

\section{CARbon Isotopes $\left(\delta^{13} \mathrm{C}\right)$}

The analytical approach to measuring $\delta^{18} \mathrm{O}$ results in the synchronous measurement of $\delta^{13} \mathrm{C}$, the deviation from a standard of the carbon isotopic ratio $\left({ }^{13} \mathrm{C} /{ }^{12} \mathrm{C}\right)$, reported in the same " $\delta$ " notation as oxygen isotopes:

$$
\begin{aligned}
\delta^{13} \mathrm{C}_{\text {sample }}= & 1000 \times\left[\left({ }^{13} \mathrm{C} /{ }^{12} \mathrm{C}\right)_{\text {sample }}-\left({ }^{13} \mathrm{C} /{ }^{12} \mathrm{C}\right)_{\text {standard }}\right] / \\
& \left({ }^{13} \mathrm{C} /{ }^{12} \mathrm{C}\right)_{\text {standard }}
\end{aligned}
$$

Whereas the ambient temperature and the $\delta^{18} \mathrm{O}$ value of seawater $\left(\delta_{\mathrm{w}}\right)$ determine the $\delta^{18} \mathrm{O}$ value recorded in foraminiferal tests, the $\delta^{13} \mathrm{C}$ value is primarily a function of the dissolved inorganic carbon (DIC) $\delta^{13} \mathrm{C}$ value in seawater (e.g., Urey, 1947; Epstein and others, 1953; Emiliani, 1955; O'Neil and others, 1969; Graham and others, 1981; McCorkle and others, 1990).

The average $\delta^{13} \mathrm{C}$ signature of the ocean's DIC reservoir on timescales longer than the residence time of carbon in the oceans $(\sim 180 \mathrm{kyr})$ is controlled by the $\delta^{13} \mathrm{C}$ signatures and fluxes of carbon sources and sinks. Carbon is supplied to the ocean from hydrothermal/volcanic outgassing and from chemical weathering of continental rocks, while carbon is removed from the ocean through deposition of carbonate and organic carbon in marine sediments. Over millions of years, these sediments integrate large kinetic fractionations from the photosynthetic reduction of $\mathrm{CO}_{2}$ to organic matter with small thermodynamic fractionations from ion exchange reactions during carbonate precipita- 

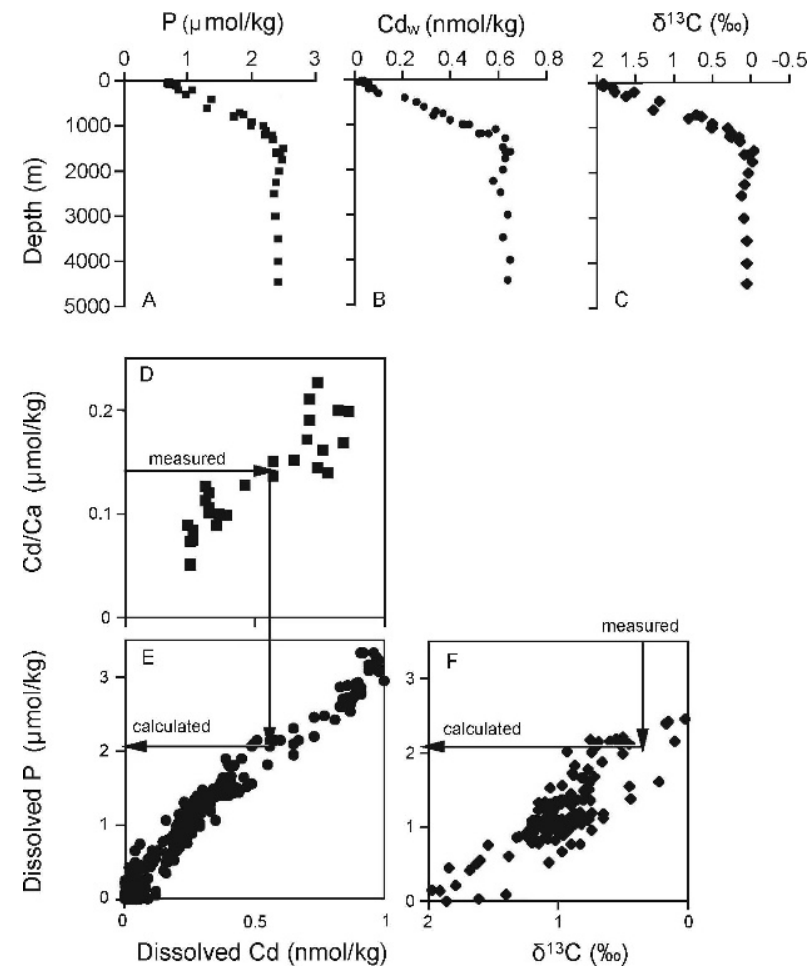

FIGURE 3. Vertical profiles of: A) phosphate; B) dissolved cadmium $\left(\mathrm{Cd}_{\mathrm{w}}\right)$; and $\mathrm{C}$ ) carbon isotopes $\left(\delta^{13} \mathrm{C}\right)$ of DIC from the Southern Ocean depicting the strong similarity among the major nutrient and the nutrient-like properties. Using measurements of $\mathrm{Cd} /$ $\mathrm{Ca}$ and $\delta^{13} \mathrm{C}$ in benthic foraminifera and the modern relationships between these properties allows us to reconstruct both dissolved $\mathrm{P}$ concentration in the past and changes in deep ocean circulation. D) Core-top calibration between benthic foraminiferal $\mathrm{Cd} / \mathrm{Ca}$ and bottom-water concentrations of dissolved $\mathrm{Cd}$ for deep cores. For intermediate depths, the partition coefficient varies with water depth, linearly increasing from 1.3 at depths $\leq 1.3 \mathrm{~km}$ to a value of 2.9 at depths $>3 \mathrm{~km}$ (Boyle, 1992). E) The modern $\mathrm{Cd}=\mathrm{P}$ relationships in deep waters is described using two equations: for $\mathrm{P}<1.3, \mathrm{Cd}_{\mathrm{w}}=$ $0.21^{*} \mathrm{P}$; and for $\mathrm{P}>1.3, \mathrm{Cd}_{\mathrm{w}}=0.40(\mathrm{P}-1.3)+0.279$, where $\mathrm{P}$ is in $\mu \mathrm{mol} / \mathrm{kg}$ and $\mathrm{Cd}_{\mathrm{w}}$ is in $\mathrm{nmol} / \mathrm{kg}$ (Boyle, 1988). F) The modern $\delta^{13} \mathrm{C}-\mathrm{P}$ relationship in deep waters is described using the equation: $\delta^{13} \mathrm{C}=2.7-$ $1.1^{*} \mathrm{P}$

tion. Changes in carbon isotopes of marine carbonates and organic matter through time serve as archives of changes in carbon sources and sinks. For detailed summaries of the geological carbon cycle, see Hayes and others (1999), Kump and Arthur (1999), Berner (2004), and Katz and others (2005).

\section{Deepwater $\delta^{13} C$}

On shorter time scales, there are considerable differences in $\delta^{13} \mathrm{C}_{\text {DIC }}$ values throughout the oceans. For example, modern deep ocean values vary from $\sim 1.0 \%$ in the North Atlantic to $-0.5 \%$ in the North Pacific (Fig. 1). These $\delta^{13} \mathrm{C}$ differences reflect (1) the basin-to-basin fractionation caused by different source regions and deepwater circulation patterns, and (2) surface-ocean productivity and related ${ }^{12} \mathrm{C}$-enriched carbon export from the surface to the deep ocean (Kroopnick, 1985) (Fig. 3). In the modern ocean, deepwater source regions in the North Atlantic and
Southern Ocean are differentiated by temperature, salinity, and nutrient content. Interbasinal $\delta^{13} \mathrm{C}$ fractionation occurs primarily because of differences in initial nutrient and $\delta^{13} \mathrm{C}$ content of deepwater formed in different locations, and secondarily because the $\delta^{13} \mathrm{C}$ value and nutrient content of deep/bottom waters changes as a function of the amount of time the water mass has been isolated from the surface. For example, whereas the Atlantic vs. Pacific $\delta^{13} \mathrm{C}$ contrast in the modern ocean reflects aging, the $\delta^{13} \mathrm{C}$ contrast in the deep Atlantic behaves conservatively and represents a mixing between North Atlantic deepwater and Antarctic bottom water end-member components. This is shown by the fact that the $\delta^{13} \mathrm{C}$ distribution of the deep Atlantic mimics salinity (Wright and others, 1991).

The distinct $\delta^{13} \mathrm{C}$ characteristics of different deepwater masses have been exploited to reconstruct deepwater circulation patterns (Figs. 1, 3). The deepwater $\delta^{13} \mathrm{C}_{\mathrm{DIC}}$ is recorded in the $\mathrm{CaCO}_{3}$ tests of benthic foraminifera, providing a means to reconstruct DIC through time and space. Thus, for times when the nutrient $/ \delta^{13} \mathrm{C}$ characteristics of each deepwater source region are very different (e.g., Neogene), carbon isotope records from deep-ocean benthic foraminifera are among the best tools available for inferring past deepwater circulation patterns. These reconstructions are done by comparing benthic foraminiferal $\delta^{13} \mathrm{C}$ values at various locations in the deep ocean and assuming that the differences reflect mixing between end-member deepwater source regions (e.g., Belanger and others, 1981; Graham and others, 1981; Curry and Lohmann, 1982; Oppo and Fairbanks, 1987; Wright and others, 1991; Wright and Miller, 1996; Poore and others, 2006; Cramer and others, 2009).

As water masses sink and move away from their source regions, ${ }^{12} \mathrm{C}$-enriched organic matter sinking from the surface ocean collects at depth, either in the water column or on the seafloor. Oxidation of this organic matter releases nutrients and $\mathrm{CO}_{2}$ with low $\delta^{13} \mathrm{C}$ values (approximately $-25 \%$ today), lowering the $\delta^{13} \mathrm{C}_{\text {DIC }}$ value and increasing nutrient levels (Fig. 3) as the deepwater mass "ages" (i.e., flows farther from its source region). Because of these processes, a deepwater mass proximal to its source region is likely to have relatively high $\delta^{13} \mathrm{C}_{\mathrm{DIC}}$ values and low nutrient levels; in contrast, the more distal (older) deepwater mass is likely to have lower $\delta^{13} \mathrm{C}_{\text {DIC }}$ values and higher nutrient levels than near the source region (Fig. 1).

\section{Surface Ocean $\delta^{13} \mathrm{C}$}

The $\delta^{13} \mathrm{C}$ recorded in planktic foraminiferal tests primarily reflects $\delta^{13} \mathrm{C}_{\text {DIC }}$ in the upper few hundred meters of the surface ocean (Fig. 2), along with the influence of foraminiferal respiration and symbiont photosynthesis (e.g., Spero and Lea, 1993; Spero and Lea, 1996; Bemis and others, 1998) (Fig. 2). The abundance of phytoplankton, both in surface waters and as symbionts in some species of planktic foraminifera, can alter the $\delta^{13} \mathrm{C}_{\mathrm{DIC}}$ on a scale that ranges from regional to the microhabitat of an individual. Additional factors may influence planktic foraminiferal $\delta^{13} \mathrm{C}$, such as test size, $\mathrm{pH}$, and light intensity (e.g., Oppo and Fairbanks, 1989; Spero and others, 1991). 


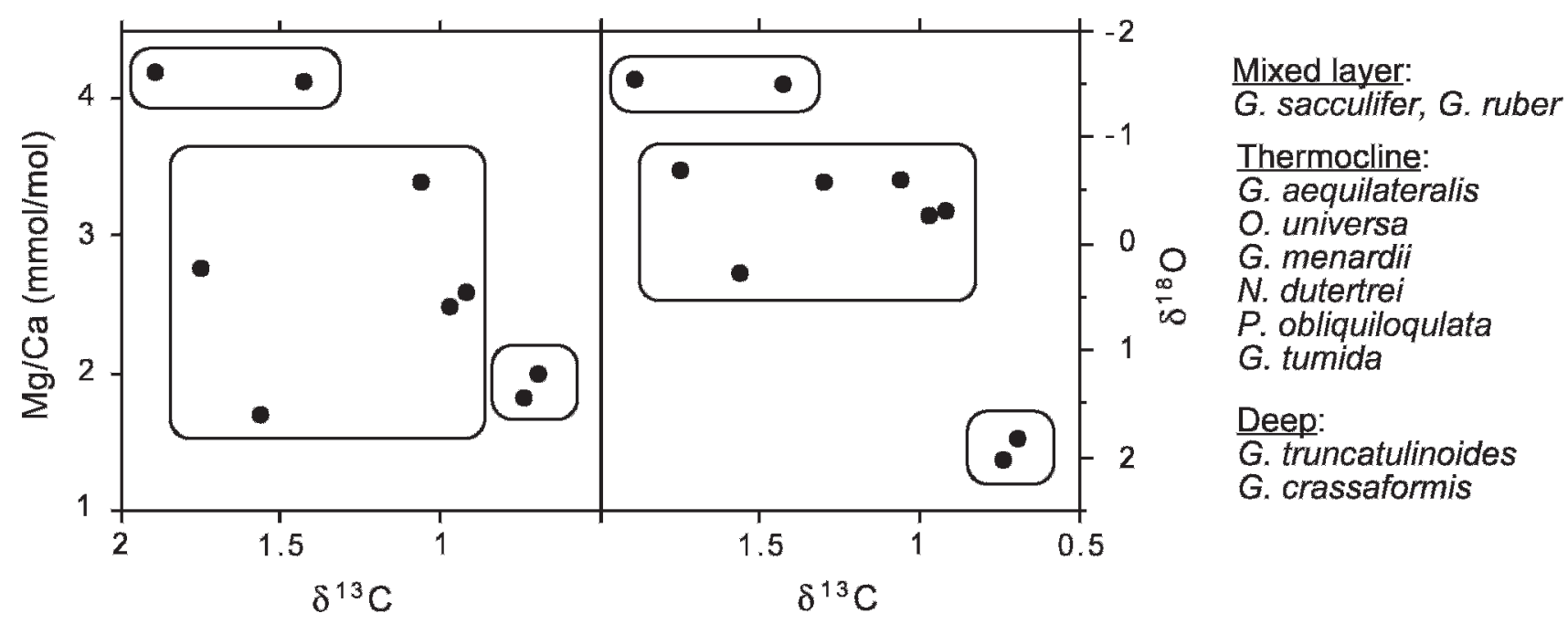

FIGURE 4. Comparison of $\delta^{18} \mathrm{O}$ and $\mathrm{Mg} / \mathrm{Ca}$ (Rosenthal and Boyle, 1993) with $\delta^{13} \mathrm{C}$ (Rosenthal, unpublished data) of planktic foraminifera from core-top samples (Sierra Leone Rise EN66 38GGC) illustrates the correspondance between depth habitat and geochemisty of foraminiferal tests. Species are grouped into mixed layer, thermocline, and deep dwellers.

Phytoplankton preferentially take up ${ }^{12} \mathrm{C}$ during photosynthesis, leaving the surrounding waters enriched in ${ }^{13} \mathrm{C}$ and yielding higher $\delta^{13} \mathrm{C}_{\text {DIC }}$. In areas of high primary and export production, phytoplankton can deplete the shallowest surface waters of ${ }^{12} \mathrm{C}$, and enrich the deeper surface waters with ${ }^{12} \mathrm{C}$. As a result, planktic foraminiferal $\delta^{13} \mathrm{C}$ decreases with depth from the sea surface to the nutricline (Figs. 2, 3) (e.g., Fairbanks and others, 1980; Curry and Crowley, 1987).

Similarly, photosynthetic symbionts enrich the microenvironment of the host foraminifera in ${ }^{13} \mathrm{C}$, resulting in $\delta^{13} \mathrm{C}_{\text {calcite }}$ that is higher than surrounding seawater (e.g., Oppo and Fairbanks, 1989; Spero and Lea, 1993). At the same time, foraminiferal respiration reintroduces ${ }^{12} \mathrm{C}$ enriched $\mathrm{CO}_{2}$ back into the DIC pool (Kroopnick, 1974). Studies have shown that there is a positive relationship between test size of symbiotic-bearing planktic foraminifera and $\delta^{13} \mathrm{C}$ (e.g., Berger, 1978; Curry and Matthews, 1981; Fairbanks and others, 1982; Oppo and Fairbanks, 1989; Spero and Lea, 1993; Billups and Spero, 1995; Faul and others, 2000).

The trend towards lower seawater temperature and ${ }^{12} \mathrm{C}$ enrichment in DIC with increasing depth in the surface ocean produces a trend towards increasing $\delta^{18} \mathrm{O}$ and decreasing $\delta^{13} \mathrm{C}$ in planktic foraminifera from the shallow mixed layer down to the base of the thermocline (Fig. 2) (e.g., Fairbanks and others, 1980; Curry and Crowley, 1987; Ravelo and Fairbanks, 1992; Faul and others, 2000). This relationship tends to produce a correlation between $\delta^{18} \mathrm{O}$ and $\delta^{13} \mathrm{C}$ in planktic foraminifera that has been documented in plankton tows (Fig. 4), and that has been utilized in fossil assemblages to reconstruct changes in the surface ocean structure and productivity (e.g., Faul and others, 2000). It has also provided the basis for reconstructions of surface ocean hydrography and productivity using extinct planktic foraminiferal species, under the assumption that the general $\delta^{18} \mathrm{O}-\delta^{13} \mathrm{C}$ relationship is valid through time (e.g., Pearson and others, 2001).

\section{Paleoproductivity: Integrated Geochemical $\left(\delta^{13} C\right)$ and Paleontological Proxies}

Numerous studies document that organic matter sinking from the surface ocean to the seafloor is the primary food supply for benthic foraminifera, and hence that surfacewater productivity ( = food supply) is a primary control on the species composition, accumulation rate, and geographic distribution of benthic foraminiferal faunas (e.g., Miller and Lohmann, 1982; Thomas and Vincent, 1987; Loubere, 1994; Rathburn and Corliss, 1994; Jorissen and others, 1995; Thomas and Gooday, 1996; Schmiedl and Mackensen, 1997; Schmiedl and others, 2000). This relationship between surface and deep water organisms is recorded in several types of geochemical and paleontological data, providing the potential to use a multi-proxy approach to constrain and monitor productivity changes through time.

A classic method used to reconstruct surface productivity and export production is to compare planktic foraminiferal $\delta^{13} \mathrm{C}$ from phosphate-free surface waters with benthic foraminiferal $\delta^{13} \mathrm{C}$ (mean deepwater proxy). As discussed above, ${ }^{12} \mathrm{C}$-enriched organic matter sinks from the surface ocean to the seafloor, driving $\delta^{13} \mathrm{C}$ of DIC higher at the surface and lower at the seafloor. Therefore, high export production drives $\delta^{13} \mathrm{C}$ higher in planktics and lower in benthics, resulting in an offset between the two, referred to as $\Delta \delta^{13} \mathrm{C}$. Whereas a paleoproductivity signal can be extracted from $\Delta \delta^{13} \mathrm{C}$, it is actually a proxy for the carbon to phosphorous ratio (C/P) (Broecker and Peng, 1982), which is proportional to productivity only as a function of stability/mixing.

Another means of estimating paleoproductivity is to compare $\delta^{13} \mathrm{C}$ of epifaunal vs. infaunal benthic foraminifera in the same sample (within the constraints of the amount of time represented in a sample by sedimentation rate). Decay of organic matter within sediments enriches porewaters in ${ }^{12} \mathrm{C}$, which can be incorporated into the tests of infaunal benthic foraminifera as they calcify. Therefore, an offset between coeval epifaunal and infaunal $\delta^{13} \mathrm{C}$ may reflect 
greater organic matter preservation within sediments than at the sediment surface, where organic matter may be oxidized before it is consumed (Mackensen and others, 1993b). When $\Delta \delta^{13} \mathrm{C}$ between epifaunal and infaunal species approaches $0 \%$ and the $\delta^{13} \mathrm{C}$ values of both are low, there was abundant food supply at the surface and within sediments (i.e., surface-water productivity was high). The higher the $\delta^{13} \mathrm{C}$, the lower the food supply, and hence, paleoproductivity.

Support for conclusions drawn from geochemical paleoproductivity proxies can be found in paleontological proxies for food availability and by extension, surfacewater productivity. The paleontological proxies must be studied using specimens from the same samples that were used to produce the geochemical records. For instance, a decrease in planktic foraminiferal flux and concomitant increase in benthic foraminiferal flux may indicate higher surface ocean primary productivity, under the assumption that a higher food supply will support more benthic foraminifera. Similarly, increases in benthic foraminiferal accumulation rates (as opposed to relative abundances) may indicate that food supply increased, thereby sustaining larger populations (e.g., Herguera, 1992). Epifaunal vs. infaunal benthic abundances are also used as a paleoproductivity indicator because epifaunal taxa tend to dominate assemblages when oligotrophic conditions prevail, whereas infaunal taxa dominate as food supply increases (e.g., Rathburn and Corliss, 1994; Jorissen and others, 1995; van der Zwaan and others, 1999). There are several trochospiral epifaunal benthic foraminiferal species that flourish in seasonal phytodetritus (e.g., Gooday, 1988; Smart and others, 1994; Loubere and Fariddudin, 1999) that are used as indicators of high export production. Thomas and Gooday (1996) identified the "phytodetritus species" Epistominella exigua (Brady) and Alabaminella weddellensis (Earland) in the Paleogene, and noted that species richness declined at southern high latitudes, but not in the Pacific tropics. This led them to speculate that expansion of these taxa in the Oligocene was the result of increased seasonal food supply at high latitudes. Finally, comprehensive benthic assemblage data have been used to estimate paleoproductivity (e.g., Loubere and Fariddudin, 1999).

\section{Benthic Foraminiferal Interspecies $\delta^{18} \mathrm{O}$ AND $\delta^{13} \mathrm{C}$ OFFSETS}

Studies that utilize geochemical analyses of foraminifera rely on the assumption that variations in foraminiferal test chemistry primarily reflect environmental changes through time or contemporaneous environmental differences related to geography or bathymetry. A potential complicating factor is that measurements of different foraminiferal species in the same sample are often consistently offset from each other and from calcite precipitated in equilibrium with the surrounding water, both in benthic (e.g., Duplessy and others, 1970; Shackleton, 1974; Belanger and others, 1981; Graham and others, 1981; McCorkle and others, 1990; Katz and others, 2003a) and planktic foraminifera (e.g., Bè and others, 1966; Fairbanks and others, 1980; Fairbanks and others, 1982; Ravelo and Fairbanks, 1992;
Spero and others, 2003). Planktic foraminiferal species isotopic offsets are discussed in the preceding sections.

Benthic foraminiferal interspecies isotopic offsets have been attributed to microhabitat differences, in which tests grow in geochemically distinct environments (e.g., Belanger and others, 1981; Corliss, 1985; McCorkle and others, 1990), presence of symbionts (e.g., Spero and Lea, 1993; Saraswati and others, 2004), and vital effects (e.g., Duplessy and others, 1970; McCorkle and others, 1990). Benthic foraminifera have different microhabitat preferences, ranging from deep infaunal to epifaunal to elevated substrates (e.g., Corliss, 1985; Gooday, 1986; Bernhard, 1989) (see Introduction).

Porewater chemistry differs from overlying seawater chemistry because organic matter decomposition within the sediments alters the porewater chemistry (e.g., Bender and others, 1977; Froelich and others, 1979; Emerson and others, 1980). In addition, porewaters may migrate within sediments. Carbon isotopes may be especially sensitive because the oxidation of organic matter within sediments lowers the $\delta^{13} \mathrm{C}_{\mathrm{DIC}}$ value of the porewater; therefore, porewater $\delta^{13} \mathrm{C}_{\mathrm{DIC}}$ profiles tend to decrease with increasing sub-seafloor depth. Isotopic analyses of modern benthic foraminifera show that epifaunal forms tend to approximate seafloor seawater values, whereas infaunal taxa are influenced by porewater values (e.g., McCorkle and others, 1990). Microhabitat effects may play a larger role than seawater $\delta^{13} \mathrm{C}$ in some settings, as concluded from a study of living benthic foraminifera in the Bay of Biscay (Fontanier and others, 2006).

Culture studies of $\delta^{18} \mathrm{O}$ and $\delta^{13} \mathrm{C}$ in Bulimina aculeata d'Orbigny and Rosalina vilardeboana d'Orbigny yielded similar results to field studies, even though maintaining culture system stability can be challenging (McCorckle and others, 2008). Systematic offsets in isotopic values of these two species, grown in the same conditions, supports speciesspecific, non-environmental controls on benthic foraminiferal test chemistry. The authors also found that very small specimens tend to be depleted in ${ }^{18} \mathrm{O}$ and ${ }^{13} \mathrm{C}$, although these ontogenetic effects are not likely to skew paleoceanographic studies that typically use substantially larger specimens (McCorckle and others, 2008). We note that the two species used in these culture studies are typically not used in paleoceanographic studies.

To avoid potential bias from vital effect and microhabitat differences, the best strategy for reconstructing past oceanographic changes is to use monospecific (specimens of the same species) or monogeneric (specimens of multiple species in the same genus) records. Many benthic foraminiferal taxa are long-lived, and therefore one species/ genus may be used to construct records spanning millions to tens of millions of years. In contrast, planktic taxa are shorter-lived in general (a few million years), necessitating spliced records from several species, corrected for interspecies offsets, for long-term planktic isotopic records. It is interesting to note that the first $\delta^{18} \mathrm{O}$ Cenozoic syntheses were based on mixed species analyses (Savin and others, 1975; Shackleton and Kennett, 1975), yet the basic features captured in these older curves are clear in more recent compilations (Miller and others, 1987; Zachos and others, 2001b; Cramer and others, 2009). This attests to the 
robustness of these records in spite of offsets due to vital effects.

\section{EFFECTS OF PH AND CARBONATE ION CONCENTRATION $\left(\left[\mathrm{CO}_{3}{ }^{2-}\right]\right)$ ON $\delta^{18} \mathrm{O}$ AND $\delta^{13} \mathrm{C}$}

Culture studies with several symbiotic and non-symbiotic planktic foraminiferal species have shown that $\delta^{18} \mathrm{O}$ and $\delta^{13} \mathrm{C}$ of the foraminiferal calcite decreases with increasing pH (Spero and others, 1997; Spero and others, 1999). This finding has been explained by the fact that as $\mathrm{pH}$ increases, the dominant form of DIC shifts from $\mathrm{HCO}_{3}{ }^{-}$to $\mathrm{CO}_{3}{ }^{2-}$, and because the fractionation of oxygen isotopes with respect to $\mathrm{H}_{2} \mathrm{O}$ is greater (i.e., higher $\delta^{18} \mathrm{O}$ ) for $\mathrm{HCO}_{3}{ }^{-}$than for $\mathrm{CO}_{3}{ }^{2-}$, the isotopic composition of calcite decreases as $\mathrm{CO}_{3}{ }^{2-}$ is increasingly used for calcification (Zeebe and others, 1999). This interpretation is supported by theoretical study of inorganically precipitated calcite (Zeebe and others, 1999), and a culture experiment with constant $\mathrm{pH}$ and variable $\left[\mathrm{CO}_{3}{ }^{2-}\right]$, which indicated that it is the $\mathrm{CO}_{3}{ }^{2-}$ : $\mathrm{HCO}_{3}{ }^{-}$ratio, rather than the $\left[\mathrm{CO}_{3}{ }^{2-}\right]$, that affects $\delta^{18} \mathrm{O}$ of Orbulina universa d'Orbigny (Bijma and others, 1999). In contrast, the carbonate ion effect on $\delta^{13} \mathrm{C}$ is mechanistically much less well understood (Zeebe and others, 1999), although the different response (i.e., $\delta^{13} \mathrm{C} \mathrm{CO}_{3}{ }^{2-}$ slope) of various foraminiferal species has been used to quantify past changes in the carbonate ion (Spero and others, 1997).

The impact of changes in $\mathrm{pH}$ through time could affect interpretations of glacial-interglacial changes and longerterm trends in isotopic records. Correcting for this effect would decrease glacial tropical SST estimates by as much as $1{ }^{\circ} \mathrm{C}$, and attribute a portion of the glacial $\delta^{13} \mathrm{C}$ decrease to increasing $\left[\mathrm{CO}_{3}{ }^{2-}\right]$ (Spero and others, 1997). In the older record, Cretaceous SSTs may have been $2-3.5^{\circ} \mathrm{C}$ warmer than initially estimated (Zeebe and Wolf-Gladrow, 2001), although the difference may be at least partially offset by lower Cretaceous $\delta_{\mathrm{w}}$ due to hydrothermal cycling of water through oceanic crust (Wallmann, 2004).

\section{CHEMOSTRATIGRAPHY}

Geochemical proxies can be used for stratigraphic correlation in one of two ways. First, for proxies (e.g., Sr isotopes) with residence times in the ocean much longer than the ocean mixing time, and substantial secular variability in the measured values, the proxy data can be converted to an age using a look-up table of age-calibrated values (Howarth and McArthur, 1997). Second, rapid changes in a geochemical proxy (typically $\delta^{18} \mathrm{O}$ or $\delta^{13} \mathrm{C}$ ) can be correlated between geographically distant sites, based on the assumption that mixing of the ocean and atmosphere requires that such changes are synchronous on $10^{3}$-yr timescales. Chronostratigraphic use of geochemical proxies includes radiometric dating $\left({ }^{14} \mathrm{C}\right)$ and identification of predictable orbitally forced cyclicity that can be directly related to temporal duration. Milankovitch orbital cycles result from gravitational interactions among Earth and the other planets, Sun, and Moon that alter Earth's orbit at regular cycles (averaging 23, 41, 100 , and $400 \mathrm{kyr}$, and 2.5 Myr). Milankovitch-scale climate variability results from amplification of orbitally driven variations in the geographic and intra-annual distribution of solar energy on Earth, which in turn affects a range of sedimentary and geochemical parameters, including the chemistry of foraminiferal tests.

\section{Stable OXYgen and CARbon Isotopes}

The value of $\delta^{18} \mathrm{O}$ in foraminifera for stratigraphic correlation was recognized even from the earliest measurements (Emiliani and Shackleton, 1974). Reconstructing Pleistocene glacial cycles was an early impetus for downcore stable isotopic measurements, and the implicit strategy of correlating glacial and interglacial maxima between widely separated sites was exploited as soon as a sufficient number of downcore records was available (Emiliani and Shackleton, 1974; Imbrie and others, 1984). This has been refined into a series of over 200 marine isotope stages, numbered within successive magnetic polarity chrons, extending into the late Miocene ( $5.3 \mathrm{Ma})$ (Lisiecki and Raymo, 2005). Correlation to this series of glacials and interglacials can be used to refine an age model derived using other methods (e.g., biostratigraphy, magnetostratigraphy), although the cyclic nature of the glacial-interglacial signal prevents using it as a primary stratigraphic tool. Recognition of the glacial imprint on older $\delta^{18} \mathrm{O}$ records has led to the designation of a series of Myr-scale Oligocene and Miocene isotope events that are $\mathrm{Myr}$ composites of higher-frequency Milankovitch changes (Oi-1 through Oi-2b and Mi-1 through Mi-7 series (Miller and others, 1991b; Pekar and Miller, 1996).

Over longer time spans, variability in the marine $\delta^{13} \mathrm{C}$ record has proven useful as a stratigraphic correlation tool. With a few exceptions (Monterey hypothesis, Vincent and Berger, 1985), the causal mechanisms for $\delta^{13} \mathrm{C}$ changes are not as clearly defined as for $\delta^{18} \mathrm{O}$. Nonetheless, $\delta^{13} \mathrm{C}$ stratigraphy has been critical in constructing robust coreto-core correlations to allow reconstruction of variations in deepwater circulation (e.g., Wright and Miller, 1996) and to test the synchrony of biostratigraphic datums (Cramer and others, 2003).

In conjunction with the Milankovitch theory of glacialinterglacial cycles forced by cyclic variations in Earth's orbital geometry, the recognition of glacial-interglacial cyclicity led to early use of $\delta^{18} \mathrm{O}$ cyclicity as a chronostratigraphic tool. The tuning of $\delta^{18} \mathrm{O}$ records to an ice-volume model driven by summer insolation at $65^{\circ} \mathrm{N}$, which varies with the orbital geometry, was the foundation of the SPECMAP timescale (Imbrie and others, 1984; Martinson and others, 1987) and culminated in the recalibration of the age of Brunhes/Matuyama magnetic polarity reversal (Shackleton and others, 1990). This strategy of tuning the $\delta^{18} \mathrm{O}$ record is still used (e.g., Lisiecki and Raymo, 2005), although it may create the impression that ice volume is more linearly related to insolation than is actually the case (Huybers and Wunsch, 2004). The orbital theory for climate change received a boost from the correlation of the $\sim 100 \mathrm{kyr}$ variability with periodic variability in the eccentricity of Earth's orbit around the Sun (Hays and others, 1976). However, the $\delta^{18} \mathrm{O}$ spectrum in the 10 cycles/ Myr range has never fit the spectrum of eccentricity very well (e.g., Kominz and Pisias, 1979), precluding a simple 
model for orbital forcing of the Pleistocene glacialinterglacial cycles (e.g., Imbrie and others, 1993). It has been suggested that the large Pleistocene $\sim 100$-kyr cycles in $\delta^{18} \mathrm{O}$ result from temperature changes due to atmospheric $\mathrm{CO}_{2}$ responding to oceanographic changes in the Southern Ocean, and largely independent of Northern Hemisphere ice sheets (Shackleton, 2000; Toggweiler, 2008). Most orbital stratigraphies in the pre-Pliocene instead rely on tuning of sedimentary parameters (e.g., $\% \mathrm{CaCO}_{3}$, magnetic susceptibility), with the resulting chronology used to test for orbital control on geochemical proxies (e.g., Zachos and others, 2001a; Pälike and others, 2006).

The presence of orbital cyclicity in $\delta^{13} \mathrm{C}$ records has frequently been noted, but typically not emphasized (e.g., see Zachos and others, 2001a). In the pre-Pleistocene, the eccentricity $(\sim 100 \mathrm{kyr}, \sim 400 \mathrm{kyr}$, and $\sim 2.5 \mathrm{Myr})$ cyclicity is especially pronounced (Woodruff and Savin, 1991; Zachos and others, 2001a; Palike and others, 2006). Cramer and others (2003) explained this as due to the low-pass filter effect of the carbon residence time $(\sim 100 \mathrm{kyr})$, and proposed that the eccentricity cyclicity should be used as a primary tool in constructing orbital stratigraphies especially for intervals older than $50 \mathrm{Ma}$ when the uncertainty in the orbital solution is too large to be of use as a tuning target curve.

The investigation of the orbital imprint on foraminiferal geochemical proxies is based on $\delta^{18} \mathrm{O}$ and $\delta^{13} \mathrm{C}$ records, primarily because of the relative simplicity of these measurements. At present, measurement of trace element ratios requires a large sample size that makes highresolution studies difficult. Further investigation of orbital cyclicity in other geochemical proxies should be of interest, both in constraining the climate response to orbital forcing and in establishing the robustness of the proxies.

\section{STRONTIUM ISOTOPES}

Two isotopes of strontium $\left({ }^{87} \mathrm{Sr},{ }^{86} \mathrm{Sr}\right)$ are introduced into the oceans through: 1) hydrothermal exchange, primarily at mid-ocean ridges (low ${ }^{87} \mathrm{Sr} /{ }^{86} \mathrm{Sr}$ values, $\sim 0.703$ ); and 2 ) continental erosion (high ${ }^{87} \mathrm{Sr} /{ }^{86} \mathrm{Sr}$ values, $\sim 0.718$ ). However, the average ${ }^{87} \mathrm{Sr} r{ }^{86} \mathrm{Sr}$ in seawater may be complicated by changes in dominant continental source rock type (e.g., Ravizza, 1993) and variable riverine fluxes (e.g., Lear and others, 2003). The ${ }^{87} \mathrm{Sr} /{ }^{86} \mathrm{Sr}$ ratio in seawater is essentially uniform at any given time because the residence time (2$4 \mathrm{Myr}$ ) is much longer than oceanic mixing times (Broecker and Peng, 1982). Note the much smaller short-term variability relative to long-term variability in ${ }^{87} \mathrm{Sr} /{ }^{86} \mathrm{Sr}$, in contrast with large short-term variability in $\delta^{18} \mathrm{O}$ and $\delta^{13} \mathrm{C}$ (Fig. 1).

Strontium can substitute for calcium during calcification of foraminiferal tests. The ${ }^{87} \mathrm{Sr} /{ }^{86} \mathrm{Sr}$ ratio of the seawater is preserved in foraminiferal tests, provided diagenetic alteration does not occur (Elderfield, 1986). Strontium isotope ratios provide an important correlation tool in stratigraphic studies of marine sediments with a precision as good as $\pm 0.3 \mathrm{Myr}$ during times of high rates of change or inflection points in the ${ }^{87} \mathrm{Sr} /{ }^{86} \mathrm{Sr}$ record. For example, ${ }^{87} \mathrm{Sr} /{ }^{86} \mathrm{Sr}$ can provide good stratigraphic control for much of the late Eocene to Recent because of changing ${ }^{87} \mathrm{Sr} /{ }^{86} \mathrm{Sr}$ values (Fig. 1; Burke, 1982; DePaolo, 1985; Hess, 1986).
Sr-isotope stratigraphy using foraminifera has the potential to significantly enhance stratigraphic resolution in sections where biomagnetostratigraphy is poor or lacking, such as in the Arctic (McNeil and Miller, 1990), in shallow-water sections (Miller and others, 1988; Sugarman and others, 1993), and in the Oligocene (Hess and others, 1986). Because of the long residence time and uniform distribution of $\mathrm{Sr}$ isotopes in the oceans, mixed planktic and benthic foraminifera from a single sample can be analyzed without concern for potential surface vs. deep ocean signal bias.

Reference sections for ${ }^{87} \mathrm{Sr} /{ }^{86} \mathrm{Sr}$ analyzed in foraminiferal samples have been developed using magnetobiostratigraphic correlations (Fig. 1). Composite records from different sites have been developed because no single site contains a complete, unaltered Cenozoic section (DePaolo and Ingram, 1985; Hess and others, 1986; McKenzie and others, 1988; Hodell and others, 1991; Hodell and Woodruff, 1994). Farrell and others (1995) compiled a record for the late Neogene (0-7 Ma) from Ocean Drilling Program (ODP) Site 758. Hess and others (1986) produced a record from 137 samples for the entire Cenozoic. Miller and others (1991a) and Olsick and others (1994) developed a lower to middle Miocene reference section at North Atlantic Deep Sea Drilling Project (DSDP) Site 608 that has a very good magnetostratigraphic record, and compares well with DSDP Site 588 (Hodell and others, 1991). Miller and others (1988) and Reilly and others (2002) compiled an Oligocene Sr-isotope reference section from DSDP Site 522 that has an excellent magnetochronology. Sr-isotopc variations were very small during the Paleocene-Eocene, limiting stratigraphic resolution (Hodell and others, 2007). Rates of change in the Maestrichtian were sufficiently high to yield $\pm 1 \mathrm{Myr}$ resolution when calibrated to paleomagnetics at South Atlantic DSDP Site 525 (Sugarman and others, 1993).

In this paper, we include a new Maestrichtian through Cenozoic compilation that uses only foraminiferal analyses (Fig. 1). The most comprehensive compilation is the "lookup table" of Howarth and McArthur (1997), which provides a record for the Jurassic to present using a variety of fossil types. However, the error analysis in their look-up tables does not reflect the full errors. Regressions provided by Oslick and others (1994) and Reilly and others (2002) for the interval 34-8 Ma provide a rigorous evaluation of age errors.

\section{MINOR AND TRACE ELEMENTS}

Minor and trace elements, which substitute for calcium (Ca) or carbonate ion $\left(\mathrm{CO}_{3}{ }^{2-}\right)$ in the crystal latticework of calcareous foraminiferal tests, have been used to reconstruct past oceanic conditions. Because the uptake of these elements is often a function of ambient environmental conditions at the time of test formation, fossil tests can provide powerful tools for a range of environmental reconstructions. Elemental ratios reported relative to $\mathrm{Ca}$ (e.g., $\mathrm{Mg} / \mathrm{Ca}, \mathrm{Cd} / \mathrm{Ca}$ ) in biogenic carbonates are especially useful because they are measured on the same phase as $\delta^{18} \mathrm{O}$ and $\delta^{13} \mathrm{C}$, reducing the uncertainties associated with using multiple proxies in reconstructions. 


\section{Foraminiferal MG/CA PALEOThermometry}

As the ocean plays a key role in climate dynamics, a full understanding of the complexity of past climate change requires thorough knowledge of variations in ocean hydrography and circulation through time. Therefore, obtaining proxies for reconstructing the oceanic distribution of temperature and salinity has been a primary objective in paleoceanography. The oceanic residence time of minor elements is relatively long (10 Myr for $\mathrm{Mg}$ and $1 \mathrm{Myr}$ for $\mathrm{Ca}$ ), resulting in constant seawater $\mathrm{Mg} / \mathrm{Ca}$ on timescales of $<10^{6}$ years (Broecker and Peng, 1982). In view of this long residence time, the possibility that temperature controls the $\mathrm{Mg}$ content of marine carbonates has been explored for decades. However, it was not until more recently that the prospects of using foraminiferal $\mathrm{Mg} / \mathrm{Ca}$ for paleothermometry have been demonstrated under both controlled laboratory and field calibrations (Nürnberg, 1995; Nürnberg and others, 1996; Rosenthal and others, 1997a; Lea and others, 1999; Elderfield and Ganssen, 2000). Following these initial studies, there has been an explosion in studies exploring both the reliability of the new proxy, and its application for reconstructing past ocean temperatures (see below).

\section{Planktic Foraminiferal Mg/Ca Paleothermometry}

$\mathrm{Mg} / \mathrm{Ca}$-paleothermometry, measured in conjunction with $\delta^{18} \mathrm{O}$, offers a distinct advantage over other SST proxies (e.g., faunal assemblage analysis and alkenone unsaturation index). Because $\mathrm{Mg} / \mathrm{Ca}$ indicates the temperature at which the foraminiferal test precipitated, it allows the estimation of the $\delta^{18} \mathrm{O}$ composition of seawater $\left(\delta_{\mathrm{W}}\right)$ (Mashiotta and others, 1999), which in turn can provide the means to reconstruct changes in ice volume and/or salinity (e.g., Lea and others, 2000; Lear and others, 2000).

The temperature dependence of $\mathrm{Mg}$ uptake in planktic foraminiferal tests has been determined using three different calibration approaches: 1) controlled culture experiments where changes in growth parameters (e.g., light, temperature, salinity, and $\mathrm{pH}$ ) are set independently of each other (e.g., Nürnberg and others, 1996; Lea and others, 1999; Russell and others, 2004; Langen and others, 2005); 2) measurements of planktic foraminiferal tests collected in sediment trap time-series from sites that are characterized by significant seasonality in SSTs (Anand and others, 2003; McConnell and Thunell, 2005; Huang and others, 2008; Mohtadi and others, 2009); and 3) analysis of fossil planktic foraminifera from core-top sediments (e.g., Elderfield and Ganssen, 2000). These calibrations suggest an exponential dependence of the $\mathrm{Mg} / \mathrm{Ca}$ content of planktic foraminifera on temperature in the form:

$$
\mathrm{Mg} / \mathrm{Ca}\left(\mathrm{mmol} \mathrm{mol}^{-1}\right)=B \mathrm{e}^{\mathrm{AT}}
$$

where $\mathrm{T}$ is the calcification temperature in ${ }^{\circ} \mathrm{K}$. In this relationship, the exponential constant $(A)$ reflects the $\mathrm{Mg}$ / $\mathrm{Ca}$ response to a given temperature change (in $\mathrm{mmol} \mathrm{mol} \mathrm{m}^{-1}$ per ${ }^{\circ} \mathrm{K}$ ), implying increased sensitivity with temperature. An examination of available data obtained by these three independent calibration methods suggests a similar temperature sensitivity for all planktic species within the range
$0.9 \pm 0.2 \mathrm{mmol} \mathrm{mol}{ }^{-1}{ }^{\circ} \mathrm{K}^{-1}(1 \mathrm{SD})$. The pre-exponential constant $(B)$ differs among the species and depends on the water depth at which each of the species calcifies (Anand and others, 2003).

The good agreement among these three calibration methods provides robust evidence that the temperature signal imprinted during test formation is generally preserved after burial of foraminiferal tests, thereby supporting the use of planktic foraminiferal $\mathrm{Mg} / \mathrm{Ca}$ for paleotemperature reconstructions. However, intra-species variability (Elderfield and Ganssen, 2000; Anand and others, 2003), diagenetic overprints including post-depositional dissolution (Rosenthal and others, 2000a; Rosenthal and Lohmann, 2002), variable contaminants (Lea and others, 2005; Pena and others, 2005; Pena and others, 2008), and methodological biases among laboratories (Rosenthal and others, 2004; Greaves and others, 2008) can introduce errors in absolute temperature reconstructions. Therefore, $\mathrm{Mg} / \mathrm{Ca}$ paleothermometry is best used to estimate relative changes in seawater temperatures.

In general, inter-species variability in $\mathrm{Mg} / \mathrm{Ca}$ is correlated with calcification depth of the planktic foraminiferal tests (Figs. 2, 4). Shallow mixed-layer dwellers (e.g., Globigerinoides ruber and Gln. sacculifer) have high $\mathrm{Mg} / \mathrm{Ca}$, whereas deep dwellers (e.g., Globorotalia tumida (Brady) and Neogloboquadrina dutertrei (d'Orbigny)) are characterized by relatively low $\mathrm{Mg} / \mathrm{Ca}$ (Bender and others, 1975; Rosenthal and Boyle, 1993). This trend is consistent with the decrease in calcification temperature with depth, as recorded by the increase in $\delta^{18} \mathrm{O}$ from mixed-layer to deep species (Fairbanks and others, 1980; Fairbanks and others, 1982). Accurate species-specific calibrations could thus allow for the reconstruction of the thermocline structure of past upper oceans (Regenberg and others, 2009). Even though this general trend is valid, it can be complicated by (1) species that calcify while migrating vertically through the water column (Hemleben and others, 1989), or (2) species that add an outer calcite crust prior to reproduction (called "gametogenic crust") at depths significantly deeper (and colder) than their principal habitat depth (e.g., Gln. sacculifer). These processes can cause significant variability in the $\mathrm{Mg}$ distribution within and among foraminiferal tests. Indeed, the "whole test" $\mathrm{Mg} / \mathrm{Ca}$ composition that is most often used for temperature reconstructions is arguably a weighted average of calcite layers formed at different depths/temperatures (Lohmann, 1995; Rosenthal and others, 2000b; Benway and others, 2003). This effect is minimal in the shallow, mixed-layer species Gln. ruber, which does not produce a gametogenic crust. In contrast, it is expressed strongly in deep-dwelling species (e.g., Neogloboquadrina dutertrei, Globorotalia tumida, and Glr. truncatulinoides (d'Orbigny)).

There is also significant test size-dependent variability in $\mathrm{Mg} / \mathrm{Ca}$ ratios among specimens of the same species. $\mathrm{Mg} / \mathrm{Ca}$ increases with increasing test size in most species, possibly because small individuals calcify faster than large individuals or because larger individuals spend relatively more time near the sea surface, where the water is warmer and the higher light intensity increases symbiont photosynthetic activity, which in turn allows growth to larger sizes (Spero and Lea, 1993; Hönisch and Hemming, 2004). In addition, 
$\mathrm{Mg} / \mathrm{Ca}$ can vary among different morphotypes of the same species, reflecting differences in growth season (e.g., the white vs. pink variety of Gln. ruber; Anand and others, 2003) or depth habitat (e.g., Gln. ruber s.s. vs. Gln. ruber s.1.; Steinke and others, 2005). The intraspecific variability implies that $\mathrm{Mg} / \mathrm{Ca}$ analyses and calibration should be performed on the same morphotypes and within a narrow size range. Also, when possible, the same size fraction should be used for both $\mathrm{Mg} / \mathrm{Ca}$ and isotopic analyses.

Interpretations of planktic foraminiferal $\mathrm{Mg} / \mathrm{Ca}$ in terms of temperature might be complicated by the fact that the uptake of $\mathrm{Mg}$ into the calcifying tests appears to depend on additional factors, including salinity and $\mathrm{pH}$. Furthermore, dissolution on the seafloor may alter the primary $\mathrm{Mg} / \mathrm{Ca}$ signal and bias paleotemperature estimates. Culture studies show a direct relationship between planktic foraminiferal $\mathrm{Mg} / \mathrm{Ca}$ and seawater salinity on the order of $5 \pm 3 \%$ per salinity unit (Lea and others, 1999; Kisakurek and others, 2008). In contrast, evidence from a surface sediment calibration in the Mediterranean Sea suggesting significantly higher salinity effect (e.g., $>16 \%$ per psu for Gln. ruber (Ferguson and others, 2008) is still controversial and at odds with the culture studies, which cover a similar salinity range. Given a temperature sensitivity of $\sim 9 \%$ per ${ }^{\circ} \mathrm{C}$, and the conservative salinity dependence, these nontemperature related effects translate to an uncertainty of 0.5 $\pm 0.3^{\circ} \mathrm{C}$ per 1 salinity unit. $\mathrm{pH}$ changes may exert an additional influence; culture data indicate an inverse $\mathrm{Mg} / \mathrm{Ca}$ dependence of about $7 \pm 5 \%$ per $0.1 \mathrm{pH}$ unit, equivalent to $-0.8 \pm 0.5^{\circ} \mathrm{C}$ per $0.1 \mathrm{pH}$ unit (Lea and others, 1999). The experimental data indicate only minimal $\mathrm{pH}$ dependence under higher-than-ambient $\mathrm{pH}$ conditions (Russell and others, 2004). While significant, these uncertainties are most likely smaller than the glacial-interglacial variability during the Pleistocene. On longer time scales, however, nontemperature related effects might have been large enough to mask SST variability when surface salinity variations were substantial. For example, the large increase in $\mathrm{Mg} / \mathrm{Ca}$ of Gln. sacculifer observed at ODP Site 1000 from 4.5-3.9 Ma has been attributed to a substantial increase in Caribbean Sea surface salinity as a result of the closure of the Panamanian Gateway (Groeneveld and others, 2008). On long time scales, variations in seawater $\mathrm{Mg} / \mathrm{Ca}$ also needs to be accounted for when estimating secular changes in temperature. One promising method for constraining changes in the $\mathrm{Mg}$ content of the oceans is $\delta^{26} \mathrm{Mg}$ (see below).

Interpretations of SST estimates based on planktic foraminiferal $\mathrm{Mg} / \mathrm{Ca}$ are also confounded by the fact that the primary $\mathrm{Mg} / \mathrm{Ca}$ ratio of planktic foraminiferal tests might be altered by post-depositional dissolution (Savin and Douglas, 1973; Lorens and others, 1977). The extent of diagenetic alteration increases with water depth and the accompanying decrease in the degree of calcite saturation (Rosenthal and Boyle, 1993; Russell and others, 1994; Brown and Elderfield, 1996). Preferential dissolution of $\mathrm{Mg}$-rich calcite (which is more susceptible to dissolution) results in a systematic decrease of $\mathrm{Mg} / \mathrm{Ca}$ ratios in planktic foraminiferal tests (Bè and others, 1975; Hecht and others, 1975; Brown and Elderfield, 1996), thereby shifting temperature estimates toward apparently colder values (Rosenthal and others, 2000a). The decrease in $\mathrm{Mg} / \mathrm{Ca}$ with depositional water depth is due to changes in each individual test, rather than due to the progressive loss of more dissolution-prone tests (Rosenthal and others, 2000a). This effect is higher in non-spinose, thermocline-dwelling species (e.g., Glr. tumida and $N q$. dutertrei) than in spinose, shallow-dwelling species (e.g., Gln. ruber and Gln. sacculifer), reflecting the larger range of water temperatures over which the deep-dwellers calcify (Brown and Elderfield, 1996; Dekens and others, 2002; Huang and others, 2008). Based on core-top calibrations, various approaches have been proposed to test and correct for dissolution effects on $\mathrm{Mg} / \mathrm{Ca}$ (Dekens and others, 2002; Rosenthal and Lohmann, 2002; Bassinot and others, 2004; Regenberg and others, 2006), but none are considered to completely compensate for the effect. However, with careful selection of samples and novel approaches to assess downcore dissolution effects on foraminiferal tests, errors associated with dissolution effects might be greatly minimized.

\section{Benthic Foraminiferal Mg/Ca Paleothermometry}

Whereas several additional proxies are available for estimating SST (e.g., faunal assemblage analysis, alkenone unsaturation index), $\mathrm{Mg} / \mathrm{Ca}$ measurements in benthic foraminifera and ostracodes are the only alternative to $\delta^{18} \mathrm{O}$ for reconstructing bottom-water temperature changes during the late Paleogene-Neogene, when large ice sheets affected the $\delta^{18} \mathrm{O}$ of seawater, and hence, of foraminiferal calcite (Fig. 1). Because benthic foraminifera calcify on (or just below) the seafloor and are preserved in the same environment in which they lived, errors related to the exact calcification water depth and post-mortem alteration are minimized in comparison to planktic foraminifera.

The first benthic foraminiferal $\mathrm{Mg} / \mathrm{Ca}$ calibration was based on the species Cibicidoides pachyderma (Rzehak) from a shallow bathymetric transect in Little Bahama Banks (LBB) that spanned a temperature range of $5-18^{\circ} \mathrm{C}$ (Rosenthal and others, 1997b). Two subsequent studies that expanded on the LBB calibration supported the initial results suggesting that the temperature sensitivity of combined Cibicidoides pachyderma and Planulina wuellerstorfi (Schwager) $\mathrm{Mg} / \mathrm{Ca}$ data is apparently identical with the $\sim 10 \%$ increase in $\mathrm{Mg} / \mathrm{Ca}$ per ${ }^{\circ} \mathrm{K}$ observed in planktic foraminifera (Lear and others, 2002; Martin and others, 2002). Similar temperature sensitivity has been observed in other benthic taxa, such as Planulina spp., Oridorsalis umbonatus (Reuss), and Melonis spp., whereas Uvigerina spp. and Planulina arimenensis d'Orbigny exhibited significantly lower sensitivity of about $6 \%$ per ${ }^{\circ} \mathrm{C}$ (Lear and others, 2002).

Using the above calibrations, paired $\delta^{18} \mathrm{O}$ and $\mathrm{Mg} / \mathrm{Ca}$ measurements in benthic foraminifera have been used to infer changes in seafloor temperature and whole-ocean seawater $\delta^{18} \mathrm{O}\left(\delta_{\mathrm{w}}\right)$ composition. Combined, these records provided new insights on Cenozoic climate history and the evolution of the cryosphere. A low-resolution benthic foraminiferal $\mathrm{Mg} / \mathrm{Ca}$ record showed a general global cooling through the Cenozoic, with the greatest cooling occurring during the Eocene and the Plio-Pleistocene (Lear 
and others, 2000; Billups, 2002; Billups and Schrag, 2003). The inferred $\delta_{\mathrm{w}}$ record suggested that the Cenozoic expansion of continental ice sheets occurred primarily in three steps, during the Eocene-Oligocene transition, the middle Miocene, and Plio-Pleistocene (Lear and others, 2000), consistent with the $\delta^{18} \mathrm{O}$ record of Cenozoic temperature and ice-volume changes (Miller and others, 1987; Zachos and others, 2001b; Cramer and others, 2009).

While initially very promising, recent studies have raised concerns about the accuracy of the above calibrations. First, it has been argued that the shallow LBB samples are compromised by diagenetic calcite overgrowths enriched in $\mathrm{Mg}$, yielding an apparent large exponential dependence on temperature. A new calibration study of $C$. pachyderma from depth transects in the Florida Straits and Great Bahama Banks, where the problem of diagenetic calcite overgrowth is minimal, suggests a linear relationship between $\mathrm{Mg} / \mathrm{Ca}$ and $\mathrm{BWT}$ of $\mathrm{Mg} / \mathrm{Ca}=0.116 \mathrm{~T}+1.2$ (i.e., a sensitivity of $\sim 0.12 \mathrm{mmol} \mathrm{mol}{ }^{-1}$ per ${ }^{\circ} \mathrm{C}$ ) for the temperature range from 5.8 to $18.6^{\circ} \mathrm{C}$ (Marchitto and others, 2007). Using a micro-analytical technique (SIMS) to avoid contamination by diagenetic overgrowth, Curry and Marchitto (2008) obtained an identical calibration on individual $C$. pachyderma samples from Bahama Banks core tops.

At the colder end of the calibration, there is growing evidence for $\mathrm{CO}_{3}{ }^{2-}$ control, which affects the incorporation of trace metals into benthic foraminiferal tests, thus significantly altering the $\mathrm{Mg} / \mathrm{Ca}$-temperature relationships in cold waters at low or under-saturated conditions with respect to carbonate minerals (Elderfield and others, 2006; Rosenthal and others, 2006). Using a global dataset, Elderfield and others (2006) proposed a carbonate ion$\mathrm{Mg} / \mathrm{Ca}$ sensitivity of $0.0086 \mathrm{mmol} \mathrm{mol}^{-1}$ per $\mu \mathrm{mol} \mathrm{kg} \mathrm{kg}^{-1}$ in calcitic benthic tests that becomes significant below $3^{\circ} \mathrm{C}$. Using a similar deep-ocean calibration, Healey and others (2008) found identical sensitivity to $\mathrm{CO}_{3}{ }^{2-}$ and a similar threshold (i.e., $\sim 3^{\circ} \mathrm{C}$ ). Interestingly, their data from the warm Sulu Sea $\left(10^{\circ} \mathrm{C}\right)$ fall right on the Marchitto and others (2007) calibration, thus lending support for a dominant temperature effect at $>3-4^{\circ} \mathrm{C}$. At colder temperatures, carbonate saturation effects may dominate, thus altering the $\mathrm{Mg} / \mathrm{Ca}$-temperature relationship ( $\mathrm{Yu}$ and Elderfield, 2008).

The aragonitic Hoeglundina elegans (d'Orbigny) may be particularly useful for reconstructing bottom-water temperatures. This species has a widespread distribution (Atlantic, Pacific, and Indian Oceans), but because of its high dissolution susceptibility, its occurrence in the geological record is sporadic in deepwater sections. Recently, core-top calibrations from Atlantic and Pacific locations showed that $\mathrm{Mg} / \mathrm{Ca}$ in Hoeglundina elegans may be used to reconstruct thermocline temperatures (Rosenthal and others, 2006). However, there is also evidence for additional significant $\mathrm{CO}_{3}{ }^{2-}$ effect on the test $\mathrm{Mg} / \mathrm{Ca}$ at low carbonate saturation levels.

Culture studies of trace elements in Bulimina aculeata and Rosalina vilardeboana yielded similar results to field studies, and show that while water chemistry is the major environmental influence on trace elemental ratios in benthic foraminifera, there are interspecies and size offsets in these ratios that can be attributed to biological processes (Hintz and others, 2006a; Hintz and others, 2006b). As with $\delta^{18} \mathrm{O}$ and $\delta^{13} \mathrm{C}$, interspecies offsets in $\mathrm{Mg} / \mathrm{Ca}$ are typically taken into account in paleoceanographic studies (e.g., Lear and others, 2000). Size-related variability in $\mathrm{Mg} / \mathrm{Ca}$ can be minimized by analyzing a narrow test size range (Hintz and others, 2006b).

While the exact magnitude of the various effects (especially temperature and $\left[\mathrm{CO}_{3}{ }^{2-}\right]$ ) is still under investigation, it is becoming clear that benthic foraminiferal $\mathrm{Mg} / \mathrm{Ca}$ thermometry is not as straightforward as initially thought. Although it is still likely that in warm, saturated waters (e.g., upper thermocline), secondary effects may have only a small influence on seafloor temperature estimates from $\mathrm{Mg} / \mathrm{Ca}$, they may lead to a large bias in deep waters where changes in temperature and $\mathrm{CO}_{3}{ }^{2-}$ saturation occur concomitantly.

In conclusion, at this time there is a large uncertainty about the application of benthic foraminiferal $\mathrm{Mg} / \mathrm{Ca}$ for estimating deep-ocean temperatures in cold and unsaturated conditions. There is also some uncertainty about the nature of the calibration under warm temperatures and over-saturated conditions (Bryan and Marchitto, 2008). Interestingly, estimation of Cenozoic bottom-water temperatures remain largely consistent using the calibration of Lear and others (2002) (Katz and others, 2008; Cramer and others, 2009).

$M g$ Isotopes $\left(\delta^{26} \mathrm{Mg}\right)$

As discussed above, the $\mathrm{Mg} / \mathrm{Ca}$ ratio in foraminiferal calcite is stongly influenced by environmental parameters, including temperature and seawater $\mathrm{Mg}$ content. An emerging proxy that holds promise for providing constraints on $\mathrm{Mg} / \mathrm{Ca}$ changes through time is $\delta^{26} \mathrm{Mg}$. In contrast to $\mathrm{Mg} / \mathrm{Ca}$, the $\mathrm{Mg}$-isotope uptake $\left(\delta^{26} \mathrm{Mg}\right)$ shows no significant correspondance to environmental changes, such as temperature or pH (Pogge von Strandmann, 2008). Rather, mechanisms that dominate $\mathrm{Mg}$ isotopic fractionation are continental weathering ( $\mathrm{Mg}$ source) and dolomite formation ( $\mathrm{Mg}$ sink). Very little fractionation occurs during hydrothermal exchange, and ion-exchange reaction with clays is a very small sink. Hence, changes in foraminiferal $\delta^{26} \mathrm{Mg}$ should reflect changes in the $\mathrm{Mg}$ sources and sinks through time. The $10 \mathrm{Myr}$ residence time of $\mathrm{Mg}$ in the oceans (Berner and Berner, 1996) is ideally suited to constrain long-term global variations in source and sink Mg fluxes (Pogge von Strandmann, 2008).

\section{Trace Element Nutrient Proxies}

Unlike $\mathrm{Mg}$ and $\mathrm{Ca}$, which exhibit conservative behavior in the ocean (i.e., maintain constant proportion with salinity), the distribution of the trace elements cadmium $(\mathrm{Cd})$, zinc $(\mathrm{Zn})$, and barium $(\mathrm{Ba})$ in the ocean varies spatially and temporally on much shorter time scales. These trace elements exhibit a nutrient-like behavior, being depleted in surface waters and enriched at depth, following the cycling of organic matter and its redistribution by deepwater circulation (Bruland, 1983). These trace elements have initially been explored as potential proxies for nutrient paleochemistry, as it relates to changes in productivity. 

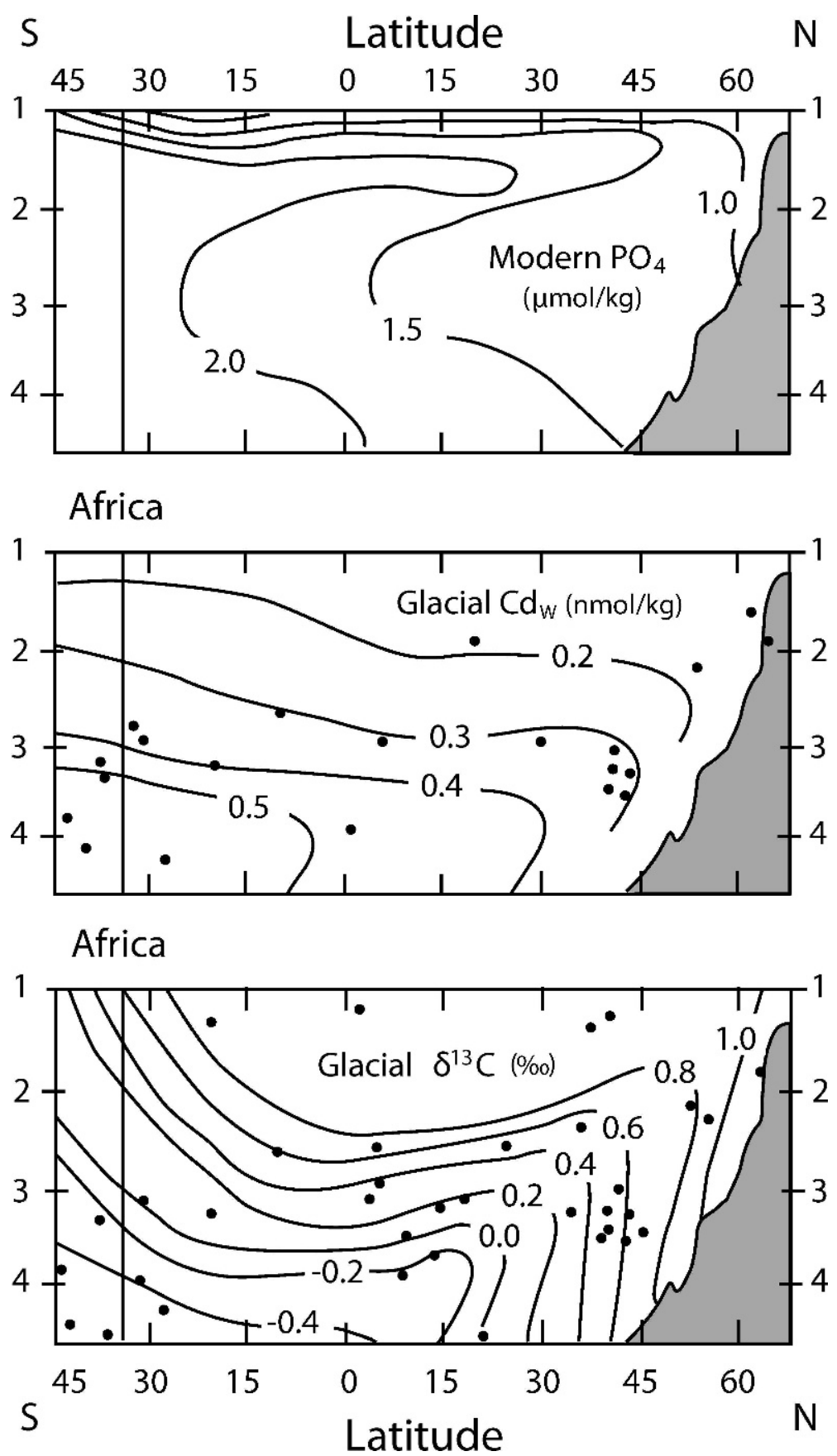

FIGURE 5. Geochemical sections through the western Atlantic Ocean depicting: the modern distribution of labile nutrient phosphate (A), and the glacial distributions of $\mathrm{Cd}(\mathrm{B})$ and $\delta^{13} \mathrm{C}(\mathrm{C})$ in seawater, reconstructed from analyses of benthic foraminifera in cores at different water depths. In the same way that phosphate is used in the modern ocean to trace the different deep ocean masses, the seawater distribution of $\mathrm{Cd}\left(\mathrm{Cd} \mathrm{w}_{\mathrm{w}}\right)$ and $\delta^{13} \mathrm{C}$ are used as nutrient (phosphate) analogs to reconstruct variations in past ocean circulation. Although similar, $\mathrm{Cd}_{\mathrm{w}}$, unlike $\delta^{13} \mathrm{C}$, is not affected by air-sea $\mathrm{CO}_{2}$ exchange. Dots indicate depth and latitude of each sample analyzed. The vertical line marked as AFRICA delineates the transition into the Antarctic Circumpolar Current at the southern extent of the Atlantic Ocean (modified from Rosenthal [1994]).

However, subsequent studies have shown that these proxies may be better used to reconstruct deepwater circulation. This approach takes advantage of the fact that the distribution of $\mathrm{Cd}, \mathrm{Ba}$, and $\mathrm{Zn}$ in the ocean "tags" the different deepwater masses, increasing substantially with water "aging" from the North Atlantic to the North Pacific. Hence, a downcore record from sites with strong mixing gradients primarily will reflect changes in deepwater circulation and, to a lesser extent, global ocean chemistry (e.g., Boyle, 1988, 1990).

The application of trace-element proxies has played a key role in understanding recent glacial-interglacial variability. However, there has been very limited work on longer timescales (e.g., Delaney and Boyle, 1987). This is largely because of the relatively short oceanic residence time of trace elements (on the order of $10^{4}-10^{5}$ years) and the 
uncertainty about the long-term controls on their oceanic distributions. For example, on these time scales, changes in the extent of reducing (suboxic and anoxic) sediments may significantly alter the oceanic inventory of $\mathrm{Cd}$ and $\mathrm{Zn}$, independent of variations in ocean circulation. This is because precipitation of sulphidic minerals (e.g., $\mathrm{CdS}$ and $\mathrm{ZnS}$ ) in reducing sediments is the major oceanic sink for these elements (Rosenthal and others, 1995a; Rosenthal and others, 1995b).

\section{Cadmium ( $\mathrm{Cd} / \mathrm{Ca})$}

The oceanic distribution of dissolved $\mathrm{Cd}$ is highly correlated with that of phosphate $\left(\mathrm{PO}_{4}\right)$ (Fig. 5). Like $\mathrm{PO}_{4}$, the vertical distribution of $\mathrm{Cd}$ is characterized by a concentration maximum at $\sim 1 \mathrm{~km}$ water depth, reflecting its association with the degradation of labile organic matter. Although evidence suggests that $\mathrm{Cd}$ plays an important enzymatic role, especially at low $\mathrm{Zn}$ conditions (Cullen and others, 1999), it is not clear that this is sufficient to explain its ocean-wide nutrient-like distribution. The global Cd- $\mathrm{PO}_{4}$ correlation is significant, but follows a slight curve that has been attributed to differential uptake rates of $\mathrm{Cd}$ and $\mathrm{PO}_{4}$ during photosynthesis that is likely related to Fe bioavailability (Cullen, 2006; Hendry and others, 2008). Therefore, the modern Cd-P relationships in deep waters is described using two equations: 1 ) for $\mathrm{P}<1.3, \mathrm{Cd}_{\mathrm{w}}=0.21$ $\times \mathrm{P}$; and 2) for $\mathrm{P}>1.3, \mathrm{Cd}_{\mathrm{w}}=0.40 \times(\mathrm{P}-1.3)+0.279$, where $\mathrm{P}$ is in $\mu \mathrm{mol} \mathrm{kg}{ }^{-1}$ and $\mathrm{Cd}_{\mathrm{w}}$ is in $\mathrm{nmol} \mathrm{kg} \mathrm{kg}^{-1}$ (Boyle, 1988).

The high variability of, and uncertainties about, the controls on $\mathrm{Cd} / \mathrm{PO}_{4}$ ratios in surface waters and evidence for possible strong temperature control on the incorporation of Cd into planktic tests (Rickaby and Elderfield, 1999) have limited the application of planktic foraminiferal $\mathrm{Cd} / \mathrm{Ca}$ for reconstructing biological productivity. Furthermore, there is also a suggestion of possible diagenetic alteration of the primary $\mathrm{Cd} / \mathrm{Ca}$ signal in planktic tests that may add another complication (Ripperger and others, 2008). Instead, the real strength of this proxy has been in reconstructing deepwater circulation by taking advantage of the fact that like phosphorous, $\mathrm{Cd}$ distribution in the deep ocean reflects the flow-related mixing of different deepwater masses (Fig. 5), increasing about five-fold between the deep North Atlantic and North Pacific Oceans (e.g., Boyle and Keigwin, 1985, 1987; Boyle, 1988, 1990).

Benthic foraminiferal $\mathrm{Cd} / \mathrm{Ca}$ ratios vary proportionally to seawater $\mathrm{Cd}$ concentrations, a relationship that can be expressed in terms of the partition coefficient:

$$
D_{\mathrm{Cd}}=(\mathrm{Cd} / \mathrm{Ca})_{\text {foram }} /(\mathrm{Cd} / \mathrm{Ca})_{\text {seawater }}
$$

The $D_{\mathrm{Cd}}$ of calcareous benthic foraminifera typically used for geochemical reconstructions (e.g., Cibicidoides mundulus (Brady, Parker, and Jones), Oridorsalis umbonatus, Planulina wuellerstorfi, and Uvigerina spp.) varies with water depth, linearly increasing from 1.3 at depths $\leq 1.3 \mathrm{~km}$ to 2.9 at depths $>3 \mathrm{~km}$ (Boyle, 1992). $D_{\mathrm{Cd}}$ of cultured Bulimina aculeata is consistent with these taxa from intermediate water depths (Hintz and others, 2006a). Studies showing that temperature does not have a significant influence on the uptake of $\mathrm{Cd}$ into foraminiferal calcite (Rosenthal and others, 1997a; Marchitto, 2004) suggested that the depthdependent change in $D_{\mathrm{Cd}}$ might be related to changes in the degree of calcite saturation, which is evident in the highly undersaturated water of the deep Pacific (McCorkle and others, 1995; Marchitto and others, 2000). In contrast, the aragonitic benthic foraminifera Hoeglundina elegans has a $D_{\mathrm{Cd}}$ of 1.0 , which is invariant with depth (Boyle and others, 1995) or temperature (Rosenthal and others, 1997a).

Benthic foraminiferal $\mathrm{Cd} / \mathrm{Ca}$ reconstructions have provided important insights on glacial-interglacial variability in deep-ocean circulation (Fig. 5). In particular, the last glacial maximum (LGM) reconstruction indicates reduced extent of low-nutrient North Atlantic Deep Water (NADW) in the deep Atlantic Ocean and its presence as a shallower glacial North Atlantic Intermediate Water (GNAIW) (Boyle and Keigwin, 1987; see review by Marchitto and Broecker, 2006). Additional important information might be gained from coupled $\delta^{13} \mathrm{C}$ and $\mathrm{Cd}$ measurements, because the two tracers have somewhat different controls. Specifically, air-sea exchange affects $\delta^{13} \mathrm{C}$ but not $\mathrm{Cd}$, so combining the two can potentially reveal past air-sea processes. Applying this approach to various regions of the glacial ocean have shown that different deepwater masses had different air-sea signatures, allowing for the separation of biogeochemical aging and water-mass mixing (Lynch-Stieglitz and Fairbanks, 1994).

\section{$\operatorname{Zinc}(\mathrm{Zn} / \mathrm{Ca})$}

The distribution of dissolved $\mathrm{Zn}$ in the ocean mimics that of the nutrient silica; both are depleted in surface waters and gradually increase with depth. Unlike labile constituents $\left(\mathrm{PO}_{4}, \mathrm{Cd}\right), \mathrm{Zn}$ behaves like a refractory nutrient, with no distinct intermediate-depth concentration maximum. Zinc is an essential constituent for algal metalloenzymes, especially in diatoms, and this may explain its oceanic association with silica. Zn concentrations increase more than ten-fold between the deep North Atlantic and North Pacific, and therefore, it was initially thought that foraminiferal $\mathrm{Zn} / \mathrm{Ca}$ may be a very sensitive tracer of past deepwater circulation. However, further research has shown that the partition coefficient of $\mathrm{Zn}$ in calcareous benthic foraminifera strongly depends on saturation state. In saturated waters, $D_{\mathrm{Zn}}$ is $\sim 9$ and decreases to about $\sim 4$ in undersaturated conditions, such as found in the modern deep Pacific (Marchitto and others, 2000). Consequently, downcore benthic foraminiferal records may reflect not only changes in the mixing between the different deepwater masses, but also in situ variations in carbonate saturation state. For example, the glacial increase in deep North Atlantic $\mathrm{Zn}$ due to the increased presence of Antarctic Bottom Water (AABW) (high $\mathrm{Si}$, high $\mathrm{Zn}$, low $\left[\mathrm{CO}_{3}{ }^{2-}\right]$ ) was partially muted in $\mathrm{Zn} / \mathrm{Ca}$ because of AABW's lower saturation state.

The strong relationship between $D_{\mathrm{Zn}}$ and saturation state allows for reconstruction of past deep ocean carbonate chemistry. Using this approach, Marchitto and others (2005) have reconstructed deep equatorial Pacific $\mathrm{CO}_{3}{ }^{2-}$ over the last glacial-interglacial cycle. Their data support the " $\mathrm{CaCO}_{3}$ compensation hypothesis" (Broecker and Peng, 1987), showing a transient drop in deep-ocean 
$\mathrm{CO}_{3}{ }^{2-}$ at the beginning of the LGM, associated with the transfer of excess metabolic $\mathrm{CO}_{3}{ }^{2-}$ from the upper ocean to the deep ocean, and a subsequent reversal due to seafloor dissolution of $\mathrm{CaCO}_{3}$ (Marchitto and others, 2005).

\section{Barium ( $\mathrm{Ba} / \mathrm{Ca}$ )}

Dissolved Ba displays nutrient-like vertical distribution, with low concentrations at the surface that gradually increase with depth, similar to that of biogenic "hard parts" $\left(\mathrm{CaCO}_{3}\right.$ and $\left.\mathrm{SiO}_{2}\right)$ (Chan and others, 1977). The modern distribution of dissolved $\mathrm{Ba}$ resembles that of alkalinity, but the association might be fortuitous; whereas biogenic $\mathrm{CaCO}_{3}$ skeletons are the main carrier of alkalinity to the deep sea, the Ba export to the deep ocean is primarily through marine barite formed in decaying organic matter (Lea and Boyle, 1989; Lea, 1993, 1995). Furthermore, a recent study suggests that unlike $\mathrm{CaCO}_{3}$ dissolution that occurs largely on the seafloor, $\mathrm{Ba}$ is preferentially regenerated in the water column (Rubin and others, 2003). Consequently, despite the strong correlation between $\mathrm{Ba}$ and alkalinity in the modern ocean, its application for reconstructing past ocean alkalinity might be limited. However, as for $\mathrm{Cd}$, the large Atlantic-Pacific difference in $\mathrm{Ba}$ offers the possibility to reconstruct deepwater circulation from benthic foraminiferal $\mathrm{Ba} / \mathrm{Ca}$ (Lea and Boyle, 1989; Lea, 1990).

For the LGM, benthic foraminiferal $\mathrm{Ba} / \mathrm{Ca}$ supports the view inferred from $\mathrm{Cd} / \mathrm{Ca}$ and $\delta^{13} \mathrm{C}$ that the low-nutrient NADW was replaced by the shallower GNAIW, while the nutrient-rich AABW expanded much further northward than at present (Lea and Boyle, 1990). In contrast to $\delta^{13} \mathrm{C}$ and $\mathrm{Cd} / \mathrm{Ca}$, however, the benthic foraminiferal $\mathrm{Ba} / \mathrm{Ca}$ shows no apparent interbasinal gradient between the deep Atlantic and Pacific oceans. This indicates that the Baalkalinity relationship in the modern ocean might be different than it was in the glacial ocean, or that there are other, hitherto undiscovered, factors controlling the partitioning of $\mathrm{Ba}$ into benthic foraminiferal tests.

A potentially more promising application is using planktic foraminiferal $\mathrm{Ba} / \mathrm{Ca}$ to reconstruct past variability in riverine and glacial meltwater inputs to the ocean. River waters are concentrated in barium compared to the depleted surface ocean. A further enrichment occurs in the river-sea mixing zone as $\mathrm{Ba}$ desorbs from suspended particles in intermediate salinity waters (e.g., Hanor and Chan, 1977). Taking advantage of the fact that Ba incorporates into planktic foraminiferal tests in direct proportion to its seawater concentration and does not vary with temperature or salinity (Lea and Boyle, 1991; Lea and Spero, 1992, 1994), Ba/Ca has been successfully used to reconstruct variations in fluvial inputs to the ocean in the past (Weldeab and others, 2007). This relatively new application shows the greatest promise for the use of $\mathrm{Ba}$ as a proxy in paleoceanography.

\section{PROXIES FOR PH AND CARBONATE ION CONCENTRATION}

Paleo-pH and carbonate ion concentration $\left[\mathrm{CO}_{3}{ }^{2-}\right]$ have been estimated from the variation in size-normalized test

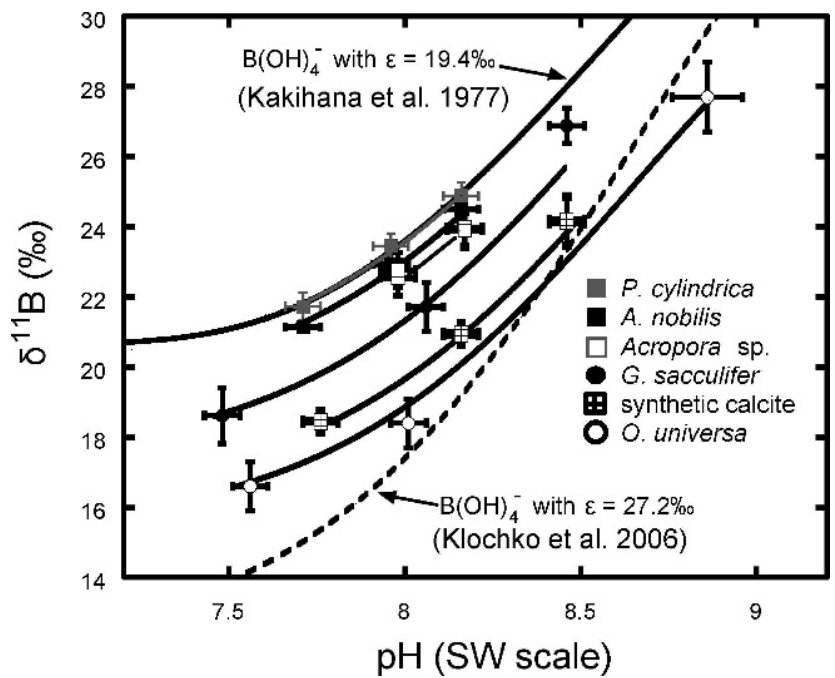

Figure 6. Empirical and theoretical calibration curves of $\delta^{11} \mathrm{~B}$ of aqueous borate (Kakihana and others, 1977; Klochko and others, 2006) and marine carbonates (Sanyal and others, 1996; Sanyal and Nugent, 2000; Sanyal and others, 2001; Hönisch and Hemming, 2004; Reynaud and others, 2004) versus seawater $\mathrm{pH}$. Note that marine carbonates are $\sim 17 \%$ lighter than $\delta^{11} \mathrm{~B}$ of seawater $(\sim 39.8 \%$ ), suggesting borate must be the dominant species incorporated into marine carbonates (Hemming and Hanson, 1992). Although offset from each other, empirical carbonate calibrations parallel $\delta^{11} \mathrm{~B}$ of borate after Kakihana and others (1977) rather than the experimental curve of Klochko and others (2006), which demonstrates the need to use species-specific empirical carbonate curves for paleo$\mathrm{pH}$ reconstructions.

weights of planktic foraminifera, with mixed results (e.g., Lohmann, 1995; Broecker and Clark, 2004). This method states that fossil test weight is a function of: 1) the test weight while the organism was alive, assuming it is determined solely by surface water $\left[\mathrm{CO}_{3}{ }^{2-}\right]$; and 2) carbonate loss after deposition, resulting from dissolution. The greater the dissolution, the lower the $\left[\mathrm{CO}_{3}{ }^{2-}\right]$ at the seafloor. However, there are additional factors that may affect fossil test weight, which can complicate interpretation solely in terms of $\left[\mathrm{CO}_{3}{ }^{2-}\right]$. Dissolution that occurs upon initial deposition cannot be distinguished from post-burial porewater dissolution, the initial test wall thickness depends on growth conditions, and environmental parameters (e.g., temperature, nutrient availability) can make it difficult to link test weight directly and exclusively to $\left[\mathrm{CO}_{3}{ }^{2-}\right]$ (Broecker and Clark, 2004). Nonetheless, test weights of planktic foraminifera have been linked to surface ocean $\left[\mathrm{CO}_{3}{ }^{2-}\right]$ (Barker and Elderfield, 2002; Moy and others, 2009).

There are three emerging geochemical proxies for seawater $\mathrm{pH}$ and $\left[\mathrm{CO}_{3}{ }^{2-}\right]$ that offer alternatives to the test weight method. Boron isotope $\left(\delta^{11} \mathrm{~B}\right)$ analyses of planktic foraminifera are the most widely studied so far. $\delta^{11} \mathrm{~B}$ in benthic foraminifera, $\mathrm{B} / \mathrm{Ca}$, and $\mathrm{U} / \mathrm{Ca}$ also show promise. In addition, the nutrient tracer $\mathrm{Zn} / \mathrm{Ca}$ can also be used as a $\left[\mathrm{CO}_{3}{ }^{2-}\right]$ proxy (see above).

\section{BORON ISOTOPES $\left(\delta^{11} \mathrm{~B}\right)$}

Boron isotopes provide a proxy for past seawater $\mathrm{pH}$, based on the equilibrium reaction between the two dominant species of $\mathrm{B}$ in seawater, boric acid $\left(\mathrm{B}(\mathrm{OH})_{3}\right)$ and borate 
$\left(\mathrm{B}(\mathrm{OH})_{4}^{-}\right)$. At low $\mathrm{pH}(<7)$, almost all $\mathrm{B}$ is present in the form of $\mathrm{B}(\mathrm{OH})_{3}$, which is enriched in ${ }^{11} \mathrm{~B}$. At high $\mathrm{pH}(>10)$, it is present in the form of $\mathrm{B}(\mathrm{OH})_{4}^{-}$, which is enriched in ${ }^{10} \mathrm{~B}$ (Fig. 6). Therefore, $\delta^{11} \mathrm{~B}$ increases with increasing $\mathrm{pH}$.

Boron isotope ratios are traditionally measured by thermal ionization mass spectrometry (TIMS), although recent developments in the field of MC-ICP-MS methods now also allow analysis of small samples (Foster, 2008). Analogous to $\delta^{18} \mathrm{O}$ and $\delta^{13} \mathrm{C}$, the boron isotopic composition is reported relative to a standard, in $\delta$ notation:

$$
\delta^{11} \mathrm{~B}_{\text {sample }}=1000 \times\left(\mathrm{R}_{\text {sample }} / \mathrm{R}_{\text {standard }}-1\right)
$$

where $\mathrm{R}$ is the isotopic ratio measured. Because marine carbonates record a boron isotopic composition that falls close to the $\delta^{11} \mathrm{~B}$ of borate, Hemming and Hemming (1992) suggested that borate must be the boron species adsorbed and incorporated into the $\mathrm{CaCO}_{3}$ lattice. This has been supported in a number of empirical calibration studies (Sanyal and others, 1996; Sanyal and Nugent, 2000; Sanyal and others, 2001; Hönisch and Hemming, 2004; Reynaud and others, 2004), where biogenic and inorganic carbonates have been grown over a wide range of seawater $\mathrm{pH}$ (Fig. 6). Based on the boron speciation in seawater and the respective isotopic composition, $\mathrm{pH}$ can be inferred from the measured $\delta^{11} \mathrm{~B}_{\text {carbonate }}$ by:

$$
\begin{aligned}
\mathrm{pH}= & \mathrm{pK} \mathrm{B}_{\mathrm{B}}-\log \left(-\left(\delta^{11} \mathrm{~B}_{\text {seawater }}-\delta^{11} \mathrm{~B}_{\text {carbonate }}+\mathrm{a}\right) /\right. \\
& \left.\left(\delta^{11} \mathrm{~B}_{\text {seawater }}-\alpha \times\left(\delta^{11} \mathrm{~B}_{\text {carbonate }}-\mathrm{a}\right)-\varepsilon\right)\right)
\end{aligned}
$$

where $\mathrm{pK}_{\mathrm{B}}$ is the equilibrium constant of the boric acid/ borate system (after Dickson, 1990), $\delta^{11} \mathrm{~B}_{\text {seawater }}=39.5 \%$, fractionation $\varepsilon=($ fractionation factor $\alpha-1) \times 1000$, and ' $\mathrm{a}$ ' is a constant offset between the theoretical borate curve and empirical calibration data for a specific sample type.

A complication in the interpretation of this system arises from the mismatch between the measured boron isotope fractionation in synthetic seawater (Klochko and others, 2006) and the shallower $\delta^{11} \mathrm{~B} / \mathrm{pH}$-curves described by the marine carbonates, which fall close to and follow the shape of the theoretical borate curve calculated from the fractionation factor determined by Kakihana and others (1977) (Fig. 6). A mechanistic explanation for this discrepancy has not yet been found, but may be related to analytical matrix effects. Because it is unacceptable to use a fractionation factor that does not fit the data, translating $\delta^{11} \mathrm{~B}$ to seawater $\mathrm{pH}$ has to rely on the species-specific empirical calibrations. Using the above $\delta^{11} \mathrm{~B} / \mathrm{pH}$ equation requires the application of the theoretical fractionation factor by Kakihana and others (1977), which is statistically the factor that best describes the shape and inflection of all empirical carbonate calibrated to date (Hönisch and others, 2007).

\section{Boron Isotopes in Planktic Foraminifera-Vital Effects and Dissolution}

Of all marine carbonates, $\mathrm{B}$ isotopes have been studied most intensively in planktic foraminifera. The $\delta^{11} \mathrm{~B} / \mathrm{pH}$ relationship of cultured Gln. sacculifer and $O$. universa has been calibrated (Fig. 6; Sanyal and others, 1996; Sanyal and others, 2001), and light experiments have quantified the effect of symbiont photosynthesis on the integrated $\mathrm{pH}$

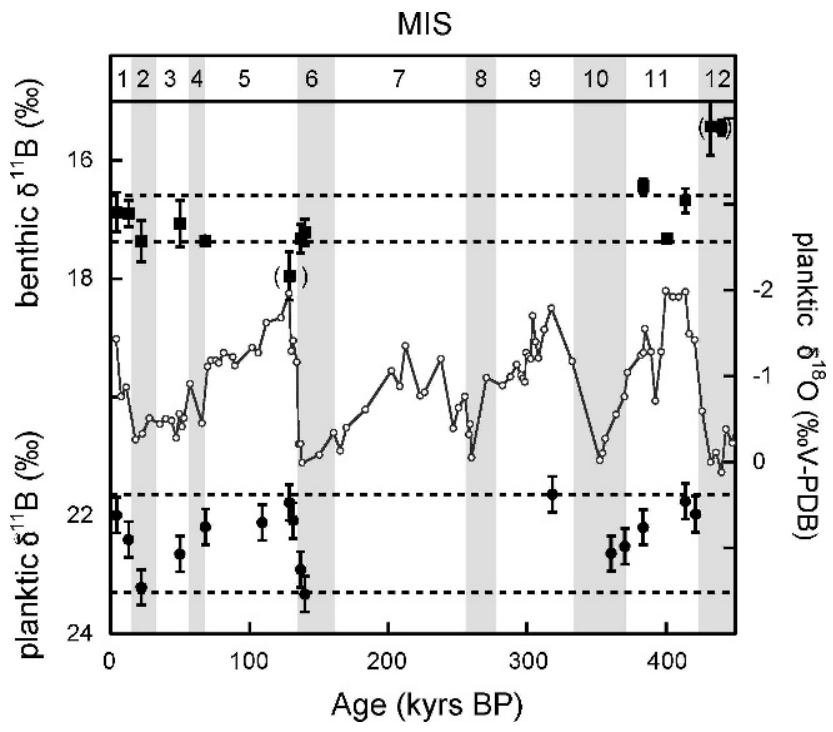

FIGURE 7. Glacial-interglacial variations in planktic and benthic foraminiferal $\delta^{11} \mathrm{~B}$, with planktic $\delta^{18} \mathrm{O}$ for reference. The range of benthic $\delta^{11} \mathrm{~B}$ is approximately half the range of planktic $\delta^{11} \mathrm{~B}$, and indicates the small glacial $\mathrm{pH}$ increase of $\sim+0.1$ unit in the deep sea, compared to $\sim 0.2$ units in the surface ocean (from Hönisch and others, 2008).

recorded by $\delta^{11} \mathrm{~B}$ in $O$. universa, which is elevated relative to the $\mathrm{pH}$ of the surrounding seawater (Hönisch and others, 2003; Zeebe and others, 2003).

This vital effect can also be observed in different test sizes of G. sacculifer, where $\delta^{11} \mathrm{~B}$ increases with test size (Hönisch and Hemming, 2004; Ni and others, 2007). Hönisch and Hemming (2004) proposed that larger tests with higher $\delta^{11} \mathrm{~B}$ reflect growth in shallower habitat, resulting in higher symbiont photosynthetic activity and therefore higher microenvironment $\mathrm{pH}$. Their depth transect studies showed that $\delta^{11} \mathrm{~B}$ decreases in deeper cores, and that the effect is stronger in the smaller sizes. This is consistent with the higher surface area to volume ratio of smaller tests, exposing more surface area to the corrosive bottom waters. This finding is supported by test weights and SEM imaging at one Atlantic site, which show that gametogenic calcite was removed during dissolution. In contrast, $\mathrm{Ni}$ and others (2007) found no $\delta^{11} \mathrm{~B}$-variation with $G$. sacculifer size, and proposed that $\delta^{11} \mathrm{~B}$ is originally uniform in all test sizes, and that dissolution causes the size effect. However, the bottom waters of all core sites studied by $\mathrm{Ni}$ and others (2007) are supersaturated with respect to calcite, their scanning electron microscope (SEM) investigation revealed that gametogenic calcite was preserved, and there is no test weight data to support their dissolution hypothesis.

The actual mechanisms for lowering $\delta^{11} \mathrm{~B}$ in partially dissolved foraminifera remains a matter of debate. Nonetheless, an important observation is that $\delta^{11} \mathrm{~B}$ of $G$. sacculifer tests $>425 \mu \mathrm{m}$ is the same for all sites (Hönisch and Hemming, 2004; Ni and others, 2007), indicating that large tests reflect surface seawater $\mathrm{pH}$. Because these are also the tests that are the least affected by dissolution, the use of large tests is recommended for paleoreconstructions (Hönisch and Hemming, 2004). In contrast to G. sacculifer, $\mathrm{Ni}$ and others (2007) demonstrated that the symbiont- 
bearing Gln. ruber does not show a test size effect. The effect of dissolution on this and other species remains to be tested further.

\section{Paleoreconstructions Based on Boron Isotopes in Planktic Foraminifera}

Surface ocean $\mathrm{pH}$-reconstructions have focused primarily on the late Pleistocene. Ocean areas where aqueous $\mathrm{pCO}_{2}$ is in equilibrium with the atmosphere can be used for reconstructing past atmospheric $\mathrm{pCO}_{2}$ variations. Such studies found glacial surface ocean $\mathrm{pH}$ consistently $\sim 0.15$ $\mathrm{pH}$ units higher than during interglacials (Sanyal and others, 1995; Sanyal and others, 1997; Hönisch and Hemming, 2005), and estimated aqueous $\mathrm{pCO}_{2}$ by pairing the $\mathrm{pH}$ estimates with paleoalkalinity, which is assumed to have changed only in response to salinity variations in the late Pleistocene (Fig. 7). The aqueous $\mathrm{pCO}_{2}$ estimates match atmospheric $\mathrm{pCO}_{2}$, as measured in Antarctic ice cores within $\pm 30 \mu \mathrm{atm}$, demonstrating the high quality and potential of $\mathrm{B}$ isotope reconstructions.

These initial validation studies led to attempts to use $\delta^{11} \mathrm{~B}$ to reconstruct the evolution of Cenozoic atmospheric $\mathrm{pCO}_{2}$, a time when benthic foraminiferal $\delta^{18} \mathrm{O}$ and $\mathrm{Mg} / \mathrm{Ca}$ reconstructions indicate large variations in Earth's climate (Miller and others, 1987; Lear and others, 2000; Zachos and others, 2001b; Cramer and others, 2009). Pearson and Palmer (2000) used planktic foraminiferal $\delta^{11} \mathrm{~B}$ to estimate surface water $\mathrm{pH}$ and atmospheric $\mathrm{pCO}_{2}$ over the past $60 \mathrm{Myr}$. Whereas their Neogene $\mathrm{pH}$ and $\mathrm{pCO}_{2}$ estimates are similar to late Pleistocene and Holocene records, their Paleogene $\mathrm{pH}$ values are as low as 7.4, and $\mathrm{pCO}_{2}$ $>3000 \mathrm{ppm}$. These estimates have been questioned for various reasons, including the use of the same $\delta^{11} \mathrm{~B} / \mathrm{pH}$ calibration curve for various sizes and extinct foraminifera, uncertainties in the $\delta^{11} \mathrm{~B}$ composition of seawater in the past (the ocean residence time of boron is only $\sim 14-20 \mathrm{Myr}$, Spivack and Edmond, 1987), and uncertainties in the DIC concentration in seawater, which Pearson and Palmer (2000) used to pair the $\mathrm{pH}$ estimates for estimating $\mathrm{pCO}_{2}$ (Demicco and others, 2003). Much more effort is required to solve these issues before Cenozoic $\mathrm{pH}$ can be estimated accurately from $\delta^{11} \mathrm{~B}$.

Upwelling areas are sources of $\mathrm{CO}_{2}$ to the atmosphere, and $\delta^{11} \mathrm{~B}$ can help to evaluate the relative strength of these sources in the past. For instance, Sanyal and others (1997) and Sanyal and Bijma (1999) studied Holocene and glacial upwelling in the eastern equatorial Pacific and off northwest Africa, respectively. Whereas glacial $\mathrm{pH}$ was 0.2 units higher off northwest Africa, $\mathrm{pH}$ remained constant in the eastern equatorial Pacific, indicating that northwest African upwelling was a smaller source of $\mathrm{CO}_{2}$ to the atmosphere than it is today. The data generated for these reconstructions are sparse, and many more cores from all major upwelling areas are needed to accurately quantify the effect of upwelling on atmospheric $\mathrm{pCO}_{2}$.

Another study focused on the transition from the LGM into the Holocene in the western equatorial Pacific (Palmer and Pearson, 2003). Between 15,600 and 13,800 years before present, surface water $\mathrm{pH}$ dropped below modern values, indicating that this area temporarily turned into a strong source of $\mathrm{CO}_{2}$ to the atmosphere. Palmer and Pearson (2003) explained this observation with increased upwelling intensity in the eastern equatorial Pacific, which could have played an important role in the deglacial $\mathrm{pCO}_{2}$ rise.

\section{$\delta^{11} B$ in Benthic Foraminifera}

The study of $\delta^{11} \mathrm{~B}$ in benthic foraminifera is in its infancy. The first studies by Sanyal and others $(1995 ; 1997)$ used mixed benthic foraminifera; their reconstructions for glacial conditions yielded higher alkaline $\mathrm{pH}(+0.3$ to $+0.5 \mathrm{pH}$ units, $\geq+100 \mu \mathrm{mol} \mathrm{kg}{ }^{-1}$ in bottom water $\left.\left[\mathrm{CO}_{3}{ }^{2-}\right]\right)$ compared to Holocene bottom water (Fig. 7). Although such high bottom-water $\mathrm{pH}$ could explain the lower glacial atmospheric $\mathrm{pCO}_{2}$, the data are inconsistent with deep-sea calcite preservation records (Sanyal and others, 1995; Anderson and Archer, 2002), which cast doubt on the validity of benthic foraminiferal $\delta^{11} \mathrm{~B}$. The concerns were subsequently corroborated by results of newly emerging deep-sea $\mathrm{CO}_{3}{ }^{2-}$ proxies, such as size-normalized test weights of planktic foraminifera (e.g., Broecker and Clark, 2004), benthic foraminiferal $\mathrm{Zn} / \mathrm{Ca}$ (Marchitto and others, 2005), and benthic foraminiferal $\mathrm{B} / \mathrm{Ca}(\mathrm{Yu}$ and Elderfield, 2007), which consistently indicate changes on the order of at most \pm 10 to $30 \mu \mathrm{mol} \mathrm{kg}{ }^{-1}$, depending on location and water depth. A likely explanation for the unreasonable and highly scattered benthic $\delta^{11} \mathrm{~B}$ data is the use of mixed species for the reconstructions. Whereas epifaunal benthic species should reflect bottom-water $\mathrm{pH}$, the contribution of infaunal benthic species would introduce a porewater $\mathrm{pH}$ signal. Alternatively, matrix or vital effects could cause a wide range of $\delta^{11} \mathrm{~B}$ offsets from the borate curve, analogous to the offsets observed between planktic foraminifera and corals (Fig. 6). Because the desired parameter is bottomwater $\mathrm{pH}$, studies need to focus on an epifaunal benthic species, such as $P$. wuellerstorfi. However, the low abundance of benthic foraminifera in sediment samples, and the supposedly low boron concentration, seemed to prohibit $\delta^{11} \mathrm{~B}$ analyses of single benthic species.

The first attempt to measure $\delta^{11} \mathrm{~B}$ in the single epifaunal benthic species Planulina wuellerstorfi found high B concentrations of $\sim 25 \mathrm{ppm}$ (Hönisch and others, 2008). This result was unexpected because planktic foraminifera contain only 7-10 ppm boron. Recent ICP-MS analyses comparing $\mathrm{B} / \mathrm{Ca}$ ratios in multiple benthic foraminiferal species indicate that $P$. wuellerstorfi may be the benthic species with the highest $\mathrm{B}$ concentration ( $\mathrm{Yu}$ and Elderfield, 2007). This allows $\delta^{11} \mathrm{~B}$ analysis with as few as 10 tests. Hönisch and others (2008) calibrated $P$. wuellerstorf $i \delta^{11} \mathrm{~B}$ from core-tops across a wide depth range (1000-4500 m) on the Walvis Ridge. A large negative offset was found from $\delta^{11} \mathrm{~B}$ of borate, but this offset was constant across the entire depth range and does not indicate a dissolution effect. Application to last glacial sediments and a downcore study on the Sierra Leone Rise revealed a much smaller $\delta^{11} \mathrm{~B}$ change compared to the previous mixed benthic species reconstruction. This puts benthic foraminiferal $\delta^{11} \mathrm{~B}$ in line with other deep ocean carbonate chemistry proxies, and although laboratory calibration over a much larger $\mathrm{pH}$ range should be acquired, $\delta^{11} \mathrm{~B}$ analysis in benthic foraminifera now appears promising. 
Trace Element PH And $\left[\mathrm{CO}_{3}{ }^{2-}\right]$ Proxies

\section{Boron $(\mathrm{B} / \mathrm{Ca})$}

Analyzing $\mathrm{B} / \mathrm{Ca}$ ratios in foraminiferal tests to reconstruct paleo-pH is an exciting new approach that may allow for a much faster sample throughput than analysis of $\delta^{11} \mathrm{~B}$ (Yu and Elderfield, 2007). Similar to the $\delta^{11} \mathrm{~B}$ proxy, $\mathrm{B} / \mathrm{Ca}$ is based on the equilibrium reaction between boric acid and borate in seawater. $\delta^{11} \mathrm{~B}$ studies indicate that borate is the species incorporated into marine carbonates, and because the seawater borate concentration increases with $\mathrm{pH}, \mathrm{B}$ uptake should increase at higher $\mathrm{pH}$. Coretop studies indicate that $\mathrm{B} / \mathrm{Ca}$ in foraminiferal calcite is strongly influenced by ambient seawater $\mathrm{pH}, \mathrm{CO}_{3}{ }^{2-}$, or temperature (Yu and others, 2007; Foster, 2008), although the studies disagree on the specific control. Yu and others (2007) have suggested that $\mathrm{Mg} / \mathrm{Ca}$ temperature estimates can be used to extract seawater $\mathrm{pH}$ changes from planktic foraminiferal $\mathrm{B} / \mathrm{Ca}$ records. A study of $\mathrm{B} / \mathrm{Ca}$ in benthic foraminifera indicates that carbonate saturation in the deep sea influences the uptake of $\mathrm{B}$ in benthic foraminifera ( $\mathrm{Yu}$ and Elderfield, 2007; Foster, 2008). A potential complicating factor in validating new paleoproxies is that carbonate chemistry and temperature often change in unison. Culture experiments under controlled laboratory conditions have been carried out to better quantify the effects of $\mathrm{pH}, \mathrm{CO}_{3}{ }^{2-}$, temperature, salinity, and $\mathrm{B}$ concentration on $\mathrm{B} / \mathrm{Ca}$ in planktic foraminifera (Allen and others, 2009).

\section{Uranium ( $\mathrm{U} / \mathrm{Ca})$}

$\mathrm{U} / \mathrm{Ca}$ in planktic foraminifera shows promise as a proxy for seawater $\left[\mathrm{CO}_{3}{ }^{2-}\right]$ (Russell and others, 1996; Russell and others, 2004). In culture experiments, $\mathrm{U} / \mathrm{Ca}$ in $O$. universa and Globigerina bulloides d'Orbigny decreases with increasing $\left[\mathrm{CO}_{3}{ }^{2-}\right]$, with a species-specific offset (Russell and others, 2004). A similar relationship has been reported in corals, but the results were also consistent with a temperature control for U/Ca (Min and others, 1995; Shen and Dunbar, 1995). In contrast, the O. universa culture experiment indicated no relationship between $\mathrm{U} / \mathrm{Ca}$ and temperature at $15-25^{\circ} \mathrm{C}$ (Russell and others, 2004). Downcore $\mathrm{U} / \mathrm{Ca}$ records in planktic foraminifera were used to reconstruct Holocene-last glaciation surface water $\left[\mathrm{CO}_{3}{ }^{2-}\right]$, and the results show good agreement with $\delta^{11} \mathrm{~B}$ and shell weights (Russell and others, 2004).

\section{NEODYMIUM ISOTOPES $\left(\varepsilon_{\mathrm{Nd}}\right)$}

An exciting new geochemical proxy is neodymium isotope ratios measured in foraminifera, which incorporate the seawater $\mathrm{Nd}$ isotope ratio as they calcify. This promises to become a powerful new tool for reconstructing past ocean structure.

Seawater $\mathrm{Nd}$ isotopes $\left({ }^{143} \mathrm{Nd} /{ }^{144} \mathrm{Nd}\right.$, expressed as $\left.\varepsilon_{\mathrm{Nd}}\right)$ are influenced by continental source rock region, and can be used to track changes in ocean circulation because $\mathrm{Nd}$ has a short residence time $(\sim 500-1000$ years $)$ relative to ocean mixing ( $\sim 1500$ years) (Goldstein and Hemming, 2003 and references therein). The variability of $\mathrm{e}_{\mathrm{Nd}}$ in the oceans is due to the distribution of old vs. young continental crust, particularly near regions of deepwater formation. The most extreme end-members in the modern ocean are the deep North Atlantic (with low $\varepsilon_{\mathrm{Nd}}$, $\sim-13.5$, derived from old continental crust) and North Pacific (with high $\varepsilon_{\mathrm{Nd}}$, from 0 to -4 , acquired from young volcanic arcs) (Goldstein and Hemming, 2003, and references therein). Variations in $\varepsilon_{\mathrm{Nd}}$ with water mass are seen both between ocean basins and in depth profiles (von Blanckenburg, 1999; Vance and others, 2004), belying its use as a water mass tracer.

Marine apatite (especially fish debris) and authigenic FeMn crusts and nodules are well established archives of past seawater $\varepsilon_{\mathrm{Nd}}$ and are useful on million year timescales, but are not applicable to high-resolution studies (e.g., Frank, 2002 and references therein). Dispersed Fe-Mn oxyhydroxide coatings on marine sediments have been exploited for this purpose (Rutberg and others, 2000; Piotrowski and others, 2005; Gutjahr and others, 2008; Piotrowski and others, 2009). However, they are subject to contamination from volcanogenic detritus (if in close proximity to volcanic islands) or pre-formed oxides (near continental margins) (e.g., Frank, 2002; Bayon and others, 2004; Piotrowski and others, 2005). Furthermore, these archives provide no records of surface-ocean circulation.

In contrast to $\varepsilon_{\mathrm{Nd}}$ sedimentary archives, foraminiferal $\varepsilon_{\mathrm{Nd}}$ offers the potential to conduct higher-resolution studies and to reconstruct surface-ocean circulation. Pioneering work on $\varepsilon_{\mathrm{Nd}}$ in core-top and plankton-tow foraminifera, along with seawater, bulk sediment, and oxide leaches, has shown that cleaned planktic foraminifera accurately record the $\varepsilon_{\mathrm{Nd}}$ of surface water, and are not measurably contaminated by Fe-Mn coatings or any post-depositional overprint (e.g., Vance and Burton, 1999; Burton and Vance, 2000; Vance and others, 2004). $\varepsilon_{\mathrm{Nd}}$ in planktic foraminifera may be complicated by vertically migrating species, such as during addition of a gametogenic crust (e.g., Globigerinoides sacculifer), if they migrate between water masses. The impact of vertical migration may be tested for by comparing $\varepsilon_{\mathrm{Nd}}$ of Gln. sacculifer with that of a shallow, mixed-layer species that does not produce a gametogenic crust (e.g., Gln. ruber). Therefore, accurate species-specific measurements of $\varepsilon_{\mathrm{Nd}}$ in planktic foraminifera could allow for the reconstruction of the shallow surface circulation and thermocline structure (Vance and others, 2004).

As a paleocirculation proxy, $\mathrm{Nd}$ isotopes hold a major advantage over nutrient-like proxies $\left(\delta^{13} \mathrm{C}, \mathrm{Cd}, \mathrm{Ba}\right.$, and $\left.\mathrm{Zn}\right)$ in that $\varepsilon_{\mathrm{Nd}}$ is not fractionated biologically or during most low-temperature processes at Earth's surface; therefore, it is not subject to vital effects, nor should it respond to changes in the mechanism or rate of $\mathrm{Nd}$ uptake. Any variability in foraminiferal $\varepsilon_{\mathrm{Nd}}$ (including interspecies variability) reflects only the seawater variability in which the foraminifera calcify. Another advantage of $\varepsilon_{\mathrm{Nd}}$ over the nutrient-like proxies is its usefulness over much longer timescales; $\varepsilon_{\mathrm{Nd}}$ can be used as a water mass tracer as long as the assumption of constant end-member compositions is valid. The $\varepsilon_{\mathrm{Nd}}$ of end-member water masses is set by the surrounding continents at the sites of deepwater formation. Therefore, the end-member $\varepsilon_{\mathrm{Nd}}$ could be altered by a significant change in location of deepwater formation or composition of adjacent exposed continental crust. 
Although foraminiferal $\varepsilon_{\mathrm{Nd}}$ appears to reliably record changes in water-mass mixing (e.g., Vance and Burton, 1999; Vance and others, 2004; Klevenz, 2008), ongoing studies will determine its ultimate utility in paleoceanographic applications. Little is known about the behavior of dissolved $\mathrm{Nd}$ in the oceans or its incorporation into foraminiferal calcite. Seawater $\varepsilon_{\mathrm{Nd}}$ exhibits quasi-conservative behavior (Goldstein and Hemming, 2002 and references therein). Although open ocean $\varepsilon_{\mathrm{Nd}}$ varies only with water mass, the concentration of $\mathrm{Nd}$ is depleted in surface waters relative to the deep ocean due to scavenging from the particle-rich surface waters. Therefore, there is a discrepancy between the behavior of $\mathrm{Nd}$ concentration and its isotope ratios in the oceans. The mechanism of $\mathrm{Nd}$ incorporation into foraminiferal tests is entirely unknown, and the apparent distribution coefficient for $\mathrm{Nd}$ into foraminiferal calcite is orders of magnitude higher than expected (e.g., Vance and others, 2004). There is also debate about adequate cleaning techniques and the presence of an unidentified refractory contaminant phase, which may or may not affect $\varepsilon_{\mathrm{Nd}}$. The use of $\varepsilon_{\mathrm{Nd}}$ in foraminifera is still being developed, and calibration studies of planktic and benthic foraminiferal $\varepsilon_{\mathrm{Nd}}$ to seawater $\varepsilon_{\mathrm{Nd}}$ should shed light on some of these issues (Vance and others, 2004).

\section{CONCLUDING REMARKS}

The three-dimensional variability of the modern ocean is relatively well constrained by direct measurements of myriad characteristics such as temperature, $\mathrm{pH}$, and nutrient content (e.g., Levitus and Boyer, 1994). In contrast, reconstructing ocean conditions through geologic history relies on inferences based on geochemical proxy records. Isotope and trace element composition of calcareous foraminifera has provided much of the foundation for reconstructions of past ocean and climate conditions, paleocirculation patterns, the carbon cycle, paleoproductivity, and marine carbonate chemistry, and also has provided an important stratigraphic tool for correlation and chronologies.

In this paper, we reviewed the geochemical proxies that utilize foraminiferal carbonate tests, including common uses of the proxies for reconstructions through time $-\delta^{18} \mathrm{O}$, $\delta^{13} \mathrm{C}$, trace elements $(\mathrm{Mg}, \mathrm{Cd}, \mathrm{Ba}, \mathrm{Zn}, \mathrm{B}, \mathrm{U}),{ }^{87} \mathrm{Sr} /{ }^{86} \mathrm{Sr}$, $\delta^{26} \mathrm{Mg}, \delta^{11} \mathrm{~B}$, and $\varepsilon_{\mathrm{Nd}}$. Employing these proxies requires an understanding of a wide range of associated factors that ultimately determine the geochemical signatures recorded in the foraminiferal calcite; discussions of these issues were also covered here.

Several of the geochemical proxies $\left(\mathrm{B} / \mathrm{Ca}, \mathrm{U} / \mathrm{Ca}, \delta^{26} \mathrm{Mg}\right.$, $\left.\delta^{11} \mathrm{~B}, \varepsilon_{\mathrm{Nd}}\right)$ are relatively new and are in the development stage for use with foraminifera. As these proxies become better understood and analytical techniques are fine-tuned, they will provide important additions to our geochemical proxy toolbox with the potential to broaden the scope of reconstructions in the near future.

\section{ACKNOWLEDGMENTS}

We thank two anonymous reviewers and Joan Bernard for comments on this manuscript.

\section{REFERENCES}

Allen, K. A., Hoenisch, B., Eggins, S. M., Spero, H. J., Yu, J., and Elderfield, H., 2009, Validating the B/Ca proxy for seawater carbonate chemistry: evidence from culture experiments with the planktic foraminifer Orbulina universa: Eos Transactions American Geophysical Union, v. 90, Fall Meeting Supplement, Abstract PP34B-04, San Francisco.

Anand, P., Elderfield, H., and Conte, M. H., 2003, Calibration of $\mathrm{Mg} / \mathrm{Ca}$ thermometry in planktonic foraminifera from a sediment trap time-series: Paleoceanography, v. 18, 1050, doi:10.1029/2002PA000846.

Anderson, D. M., and ARCher, D., 2002, Glacial-interglacial stability of ocean $\mathrm{pH}$ inferred from foraminifer dissolution rates: Nature, v. 416, p. 70-72.

Anderson, O. R., and BÈ, A. W. H., 1976, The ultrastructure of a planktonic foraminifer, Globigerinoides sacculifer (Brady), and its symbiotic dinoflagellates: Journal of Foraminiferal Research, v. 6, p. 121.

BARKer, S., and Elderfield, H., 2002, Foraminiferal calcification response to glacial-interglacial changes in atmospheric $\mathrm{CO}_{2}$ : Science, v. 297, p. 833-836.

Bassinot, F. C., Melieres, F., and Labeyrie, L., 2004, Crystallinity of foraminifera shells: a proxy to reconstruct past bottom water $\mathrm{CO}_{3}$ changes?: Geochemistry, Geophysics, Geosystems, v. 5, Q08D10, doi:10.1029/2003GC000668.

Bayon, G., German, C. R., Burton, K. W., Nesbitt, R. W., and Rogers, N., 2004, Sedimentary Fe-Mn oxyhydroxides as paleoceanographic archives and the role of aeolian flux in regulating oceanic dissolved REE: Earth and Planetary Sciences Letters, v. 224 , p. $477-492$.

BÈ, A. W. H., 1977, An ecological, oceongraphic, and taxonomic review of Recent planktonic foraminifera, in Ramsay, A. T. S. (ed.), Oceanic Micropaleontology: Academic Press, London, p. $1-100$.

- and Tolderland, D. S., 1971, Distribution and ecology of living planktonic foraminifera in surface waters of the Atlantic and Indian oceans, in Funnell, B. M., and Riedel, W. R. (eds.), Micropaleontology of Oceans: Cambridge University Press, New York, p. 105-149.

_ McIntyre, A., and Breger, D. L., 1966, Shell microstructure of a planktonic foraminifer, Globorotalia menardii (d'Orbigny): Eclogae Geologicae Helvetiae, v. 59, p. 885-896.

—, Morse, J. W., and Harrison, S. M., 1975, Progressive dissolution and ultrastructural breakdown in planktonic foraminifera, in Sliter, W. V., Bè, A. W. H., and Berger, W. H. (eds.), Dissolution of Deep-Sea Carbonates, p. 27-55.

- Spero, H. J., and Anderson, O. R., 1982, Effects of symbiont elimination and reinfection on the life processes of the planktonic foraminifer Globigerinoides sacculifer: Marine Biology, v. 70, p. $73-86$.

Belanger, P. E., Curry, W. B., and Matthews, R. K., 1981, Coretop evaluation of benthic foraminiferal isotopic ratios for paleooceanographic interpretations: Palaeogeography, Palaeoclimatology, Palaeoecology, v. 33, p. 205-220.

Bemis, B. E., Spero, H. J., Bijma, J., and Lea, D. W., 1998, Reevaluation of the oxygen isotopic composition of planktonic foraminifera: experimental results and revised paleotemperature equations: Paleoceanography, v. 13, p. 150-160.

Bender, M. L., Labeyrie, L. D., Raynaud, D., and Lorius, C., 1985, Isotopic composition of atmospheric $\mathrm{O}_{2}$ in ice linked with deglaciation and global productivity: Nature, v. 318 , p. 349352.

- Fanning, K. A., Froelich, P. N., Heath, G. R., and Maynard, V., 1977, Interstitial nitrate profiles and oxidation of sedimentary organic matter in the eastern equatorial Atlantic: Science, v. 198, p. 605-609.

- Lorens, R. B., and Williams, F. D., 1975, Sodium, magnesium and strontium in the tests of planktonic foraminifera: Micropaleontology, v. 21, p. 448-459.

Benway, H., Haley, B., Klinkhammer, G., and Mix, A. C., 2003, Adaptation of a flow-through leaching procedure for $\mathrm{Mg} / \mathrm{Ca}$ paleothermometry: Geochemistry, Geophysics, Geosystems, v. 4, 8403, doi:10.1029/2002GC000312. 
Berger, A. L., 1978, Long-term variations of caloric insolation resulting from the Earth's orbital elements: Quaternary Research, v. 9, p. $139-167$.

Berger, W. H., Killingley, J. S., and Vincent, E., 1978, Stable isotopes in deep-sea carbonates: box core ERDC-92, west equatorial Pacific: Oceanologica Acta, v. 1, p. 203-216.

Berner, E. K., and Berner, R. A., 1996, Global Environment: Water, Air and Geochemical Cycles: Prentice Hall, Old Tappan, New Jersey, $376 \mathrm{p}$.

Berner, R. A., 2004, The Phanerozoic Carbon Cycle: $\mathrm{CO}_{2}$ and $\mathrm{O}_{2}$ : Oxford University Press, Oxford, New York, 158 p.

Bernhard, J. M., 1989, The distribution of benthic foraminifera with respect to oxygen concentration and organic carbon levels in shallow-water Antarctic sediments: Limnology and Oceanography, v. 34, p. 1131-1141.

$\longrightarrow$, Sen Gupta, B. K., and Borne, P. F., 1997, Benthic foraminiferal proxy to estimate dysoxic bottom water oxygen concentrations, Santa Barbara basin, US Pacific continental margin: Journal of Foraminiferal Research, v. 27, p. 301-310.

Bijma, J., Spero, H. J., and LeA, D. W., 1999, Reassessing foraminiferal stable isotope geochemistry: impact of the oceanic carbonate system (experimental results), in Fischer, G., and Wefer, G. (eds.), Use of Proxies in Paleoceanography: Examples from the South Atlantic: Springer-Verlag, Berlin, Heidelberg, p. 489-512.

BILlups, K., 2002, Late Miocene through early Pliocene deep water circulation and climate change viewed from the sub-Antarctic South Atlantic: Palaeogeography, Palaeoclimatology, Palaeoecology, v. 185 , p. $287-307$.

— of the past 27 myr revisited with paired $\mathrm{Mg} / \mathrm{Ca}$ and stable isotope measurements on benthic foraminifera: Paleoceanography, v. 17, 1003, 10.1029/2000PA000567.

$\longrightarrow$, and $\longrightarrow$ 2003, Application of benthic foraminiferal $\mathrm{Mg} / \mathrm{Ca}$ ratios to questions of Cenozoic climate change: Earth and Planetary Science Letters, v. 209, p. 181-195.

—, and Spero, H. J., 1995, Relationship between shell size, thickness and stable isotopes in individual planktonic foraminifera from two equatorial Atlantic cores: Journal of Foraminiferal Research, v. 25, p. 24-37.

BoERsMA, A., 1985, Oligocene benthic foraminifers from North Atlantic sites: benthic foraminifers as water-mass indexes in the North and South Atlantic, in Bougault, H., Cande, S. C., and others. (eds.), Initial Reports of the Deep Sea Drilling Project, v. 82: U.S. Government Printing Office, Washington, D.C., p. 611-627.

Boyle, E. A., 1988, Cadmium: chemical tracer of deepwater paleoceanography: Paleoceanography, v. 3, p. 471-489.

, 1990, Quaternary deepwater paleoceanography: Science, v. 249, p. $863-870$.

$\longrightarrow$, 1992, Cadmium and $\delta^{13} \mathrm{C}$ paleochemical ocean distributions during the stage 2 glacial maximum: Annual Reviews of Earth and Planetary Sciences, v. 20, p. 245-287.

— paleochemical records for the last 250,000 years: changes in deep ocean circulation and chemical inventories: Earth and Planetary Science Letters, v. 76, p. 135-150.

$\longrightarrow$, and $\longrightarrow$ 1987, North Atlantic thermohaline circulation during the last 20,000 years linked to high latitude surface temperature: Nature, v. 330, p. 35-40.

—, Labeyrie, L., and Duplessy, J.-C., 1995, Calcitic foraminiferal data confirmed by cadmium in aragonitic Hoeglundina: application to the last glacial maximum in the northern Indian Ocean: Paleoceanography, v. 10, p. 881-900.

Bradshaw, J. S., 1959, Ecology of living planktonic foraminifera in the North and Equatorial Pacific Ocean: Journal of Foraminiferal Research, v. 10, p. 25-64.

Broecker, W. S., and Clark, E., 2004, Shell weights from the South Atlantic: Geochemistry, Geophysics, Geosystems, v. 5, Q03003, doi:10.1029/2003GC000625.

— , and Peng, T.-H., 1982, Tracers in the Sea: Eldigio Press, Lamont-Doherty Geological Observatory, Palisades, New York, $690 \mathrm{p}$.
glacial to interglacial atmospheric $\mathrm{CO}_{2}$ change: Global Biogeochemical Cycles, v. 1, p. 15-29.

Brown, S. J., and Elderfield, H., 1996, Variations in $\mathrm{Mg} / \mathrm{Ca}$ and $\mathrm{Sr} /$ $\mathrm{Ca}$ ratios of planktonic foraminifera caused by postdepositional dissolution: evidence of shallow $\mathrm{Mg}$-dependent dissolution: Paleoceanography, v. 11 , p. 543-551.

BRuland, K. W., 1983, Trace elements in seawater, in Riley, J. P., and Chester, R. (eds.), Chemical Oceanography: Academic Press, London, p. 157-220.

BRyAN, S. P., and MarchitTo, T. M., 2008, Mg/Ca-temperature proxy in benthic foraminifera: new calibrations from the Florida Straits and a hypothesis regarding $\mathrm{Mg} / \mathrm{Li}$ : Paleoceanography, v. 23, PA2220, doi:10.1029/2007PA001553.

Burke, W. H., Denison, R. E., Hetherington, E. A., Koepnick, R. B., Nelson, H. F., and Otто, J. B., 1982, Variation of seawater ${ }^{87} \mathrm{Sr} /{ }^{86} \mathrm{Sr}$ throughout Phanerozoic time: Geology, v. 10, p. 516-519.

Burton, K. W., and VAnce, D., 2000, Glacial-interglacial variations in the neodymium isotope composition of seawater in the Bay of Bengal recorded by planktonic foraminifera: Earth and Planetary Science Letters, v. 176, p. 425-441.

Cannariato, K. G., and Kennett, J. P., 1999, Climatically related millennial-scale fluctuations in strength of California margin oxygen-minimum zone during the past 60 k.y.: Geology, v. 27 , p. $975-978$.

Chan, L. H., Edmond, J. M., Stallard, R. F., and Grant, B., 1977, On the barium data from the GEOSECS expedition: Deep-Sea Research, v. 24, p. 613-649.

CLIMAP, 1976, The surface of the ice-age Earth: Science, v. 191, p. $1131-1144$.

_ 1981, Seasonal reconstruction of the Earth's surface at the last glacial maximum: Map and Chart Series Technical Report MC36, Geological Society of America, Boulder, Colorado, $18 \mathrm{p}$.

CoRliss, B. H., 1979a, Quaternary Antarctic bottom-water history: deep-sea benthonic foraminiferal evidence from the Southeast Indian Ocean: Quaternary Research, v. 12, p. 271-289.

_ 1979b, Recent deep-sea benthonic foraminiferal distributions in the Southeast Indian Ocean: inferred bottom water routes and ecological implications: Marine Geology, v. 31, p. 115-138.

- 1985, Microhabitats of benthic foraminifera within deep-sea sediments: Nature, v. 314, p. 435-438.

Cramer, B. S., Toggweiler, J. R., Wright, J. D., Katz, M. E., and Miller, K. G., 2009, Ocean overturning since the Late Cretaceous: Interference from a new benthic foraminiferal isotope compilation: Paleoceanography, v. 24, PA4216, doi:10.1029/ 2008PA001683.

—, Wright, J. D., Kent, D. V., and Aubry, M.-P., 2003, Orbital climate forcing of $\delta^{13} \mathrm{C}$ excursions in the late Paleocene-early Eocene (Chrons C24n C25n): Paleoceanography, v. 18, 1097, doi:1010.1029/2003PA000909.

Cullen, J. T., 2006, On the nonlinear relationship between dissolved cadmium and phosphate in the modern global ocean: Could chronic iron limitation of phytoplankton growth cause the kink?: Limnology and Oceanography, v. 51, p. 1369-1380.

- Lane, T. W., Morel, M. M. F., and Sherrell, R. M., 1999, Modulation of cadmium uptake in phytoplankton by seawater $\mathrm{CO}_{2}$ concentration: Nature, v. 402 , p. 165-167.

Curry, W. B., and Crowley, T. J., 1987, C-13 in equatorial Atlantic surface waters: Implications for ice age $\mathrm{pCO}_{2}$ levels: Paleoceanography, v. 2, p. 489-531.

$\longrightarrow$, and Lohmann, G. P., 1982, Carbon isotopic changes in benthic foraminifera from the western South Atlantic: Reconstruction of glacial abyssal circulation patterns: Quaternary Research, v. 18 , p. $218-235$.

—, and Marchitto, T. M., 2008, A secondary ionization mass spectrometry of Cibicidoides pachyderma $\mathrm{Mg} / \mathrm{Ca}$ with temperature: Geochemistry, Geophysics, Geosystems, v. 9, Q04009, doi:10.1029/2007GC001620.

— oxygen isotopic measurements on planktic foraminifera: Indian Ocean core-top evidence: Palaeogeography, Palaeoclimatology, Palaeoecology, v. 33, p. 173-191.

, Thunell, R. C., and Honjo, S., 1983, Seasonal changes in the isotopic composition of planktonic foraminifera collected in 
Panama Basin sediment traps: Earth and Planetary Science Letters, v. 64, p. 33-43.

de Steiger, H. C., Jorissen, F. J., and van der Zwaan, G. J., 1998 , Bathymetric distribution and microhabitat partitioning of live (rose Bengal stained) benthic foraminifera along a shelf to deep sea transect in the southern Adriatc Sea: Journal of Foraminiferal Research, v. 28, p. 40-65.

Dekens, P. S., Lea, D. W., PaK, D. K., and Spero, H. J., 2002, Core top calibration of $\mathrm{Mg} / \mathrm{Ca}$ in tropical foraminifera: refining paleotemperature estimation: Geochemistry, Geophysics, Geosystems, v. 3, 1022, doi:2001GC0002000.

Delaney, M. L., and Boyle, E., 1987, Cd/Ca in late Miocene benthic foraminifera and changes in the global organic carbon budget: Nature, v. 330, p. $156-159$

Demicco, R. V., Lowenstein, T. K., and Hardie, L. A., 2003 , Atmospheric $\mathrm{pCO}_{2}$ since $60 \mathrm{Ma}$ from records of seawater $\mathrm{pH}$, calcium, and primary carbonate mineralogy: Geology, v. 31, p. 793-796.

DePaolo, D. J., and Ingram, B. L., 1985, High-resolution stratigraphy with strontium isotopes: Science, v. 227, p. 938-940.

Deuser, W. G., 1987, Seasonal variations in isotopic composition and deep-water fluxes of the tests of perennially abundant planktonic foraminifera of the Sargasso Sea: results from sediment-trap collections and their paleoceanographic significance: Journal of Foraminiferal Research, v. 17, p. 14-27.

Dickson, A. G., 1990, Thermodynamics of the dissociation of boric acid in synthetic seawater from 273.15 to $318.15 \mathrm{~K}$ : Deep-Sea Research, v. 37, p. 755-766.

Donner, B., and WeFer, G., 1994, Flux and stable isotope composition of Neogloboquadrina pachyderma and other planktonic foraminifers in the Southern Ocean (Atlantic Sector): DeepSea Research, v. 41, p. 1733-1743.

Duplessy, J. C., Lalou, C., and Vinot, A. C., 1970, Differential isotopic fractionation in benthic foraminifera and paleotemperatures re-assessed: Science, v. 168, p. 250-251.

Dutton, A., Lohmann, K. C., and Leckie, R. M., 2005, Data report: Stable isotope and $\mathrm{Mg} / \mathrm{Ca}$ of Paleocene and Eocene foraminifers, ODP Site 1209, Shatsky Rise, in Bralower, T. J., Premoli Silva, I., and Malone, M. J. (eds.), Proceedings of the Ocean Drilling Program, Scientific Results, v. 198: Ocean Drilling Program, College Station, Texas, p. 1-19.

Elderfield, H., 1986, Strontium isotope stratigraphy: Palaeogeography, Palaeoclimatology, Palaeoecology, v. 57, p. 71-90.

-, and Ganssen, G., 2000, Past temperature and $\delta^{18} \mathrm{O}$ of surface ocean waters inferred from foraminiferal $\mathrm{Mg} / \mathrm{Ca}$ ratios: Nature, v. 405 , p. $442-445$.

-, Yu, J., Anand, P., Kiefer, T., and Nyland, B., 2006, Calibrations for benthic foraminiferal $\mathrm{Mg} / \mathrm{Ca}$ paleothermometry and the carbonate ion hypothesis: Earth and Planetary Science Letters, v. 250, p. 633-649.

Emerson, S., Jahnke, R., Bender, M., Froelich, P., Klinkhammer, G., Bowser, C., and Setlock, G., 1980, Early diagenesis in sediments from the eastern equatorial Pacific, I. Pore water nutrient and carbonate results: Earth and Planetary Science Letters, v. 49 , p. $57-80$

Emiliani, C., 1955, Pleistocene temperature variation in the Mediterranean: Quaternaria, v. 3, p. 109-124.

—_, and Shackleton, N. J., 1974, The Brunhes epoch: isotopic paleotemperatures and geochronology: Science, v. 183, p. $511-514$.

Epstein, S., Buchsbaum, R., Lowenstam, H. A., and Urey, H. C., 1953, Revised carbonate-water isotopic temperature scale: Geological Society of America Bulletin, v. 64, p. 1315-1326.

Fairbanks, R. G., and Matthews, R. K., 1978, The marine oxygen isotopic record in Pleistocene coral, Barbados, West Indies: Quaternary Research, v. 10, p. 181-196.

, Sverdlove, M., Free, R., Wiebe, P. H., and Be, A. W. H., 1982, Vertical distribution and isotopic fractionation of living planktonic foraminifera in the Panama Basin: Nature, v. 298, p. 841-844.

_, and Wiebe, P. H., 1980, Foraminifera and chlorophyll maximum: vertical distribution, seasonal succession and paleoceanographic significance: Science, v. 209, p. 1524-1526.
Wiebe, P. H., and Be, A. W. H., 1980, Vertical distribution and isotopic composition of living planktonic foraminifera in the western North Atlantic: Science, v. 207, p. 61-63.

Farrell, J. W., Clemens, S. C., and Gromete, L. P., 1995, Improved chronostratigraphic reference curve of late Neogene seawater ${ }^{87} \mathrm{Sr} /{ }^{86} \mathrm{Sr}$ : Geology, v. 23 , p. $403-406$.

Faul, K. L., Ravelo, A. C., and Delaney, M. L., 2000, Reconstructions of upwelling, productivity, and photic zone depth in the eastern equatorial Pacific Ocean using planktonic foraminiferal stable isotopes and abundances: Journal Foraminiferal Research, v. 30 , p. $110-125$.

Ferguson, J. E., Henderson, G. M., Kucera, M., and Rickaby, R. E. M., 2008, Systematic change of foraminiferal $\mathrm{Mg} / \mathrm{Ca}$ ratios across a strong salinity gradient: Earth and Planetary Science Letters, v. 577, p. 153-166.

Fontanier, C., Mackensen, A., Jorissen, F. J., Anschutz, P., LicAri, L., and Griveaud, C., 2006, Stable oxygen and carbon isotopes of live benthic foraminifera from the Bay of Biscay: microhabitat impact and seasonal variability: Marine Micropaleontology, v. 58, p. 159-183.

Foster, G. L., 2008, Seawater $\mathrm{pH}, \mathrm{pCO}_{2}$ and $\left[\mathrm{CO}_{2}{ }^{-3}\right]$ variations in the Caribbean Sea over the last 130 kyr: a boron isotope and $\mathrm{B} / \mathrm{Ca}$ study of planktic foraminifera: Earth and Planetary Science Letters, v. 271, p. 254-266.

FRANK, M., 2002, Radiogenic isotopes: tracers of past ocean circulation and erosional input: Reviews of Geophysics, v. 40, 1001, doi:10.1029/2000RG000094.

Froelich, P. N., Klinkhammer, G. P., Bender, M. L., Luedtke, N. A., Heath, G. R., Cullen, D., and Dauphin, P., 1979, Early oxidation of organic matter in pelagic sediments of eastern equatorial Atlantic: suboxic diagenesis: Geochimica et Cosmochimica Acta, v. 43, p. 1075-1090.

Goldstein, S. L., and Hemming, S. R., 2003, Long-lived isotopic tracers in oceanography, paleoceanography, and ice-sheet dynamics, in Elderfield, H. (ed.), The Oceans and Marine Geochemistry, v. 6, p. 453-489.

GoodAy, A. J., 1986, Meiofaunal foraminiferans from the bathyal Porcupine Seabight (Northeast Atlantic): size structure, standing stock, species diversity and vertical distribution in the sediment: Deep-Sea Research, v. 33, p. 1345-1373.

-, 1988, A response by benthic foraminifera to the deposition of phytodetritus in the deep sea: Nature, v. 332, p. 70-73.

- 1994, The biology of deep-sea foramininfera: a review of some advances and their applicatiuons in paleoceanography: Palaios, v. 9 , p. $14-31$

, 2003, Environmental influences on faunal characteristics: benthic foraminifera (Protista) as tools in deep-water palaeoceanography: Advances in Marine Biology, v. 46, p. 1-90.

- and RAthBuRN, A. E., 1999, Temporal variability in living deep-sea benthic foraminifera: a review: Earth-Science Reviews, v. 46, p. $187-212$.

Graham, D. W., Corliss, B. H., Bender, M. L., and Keigwin, L. D., JR., 1981, Carbon and oxygen isotopic disequilibria of Recent deep-sea benthic foraminifera: Marine Micropalentology, v. 6, p. 483-497.

Greaves, M., Caillon, N., and others, 2008, Interlaboratory comparison study of calibration standards for foraminiferal $\mathrm{Mg} / \mathrm{Ca}$ thermometry: Geochemistry, Geophyics, Geosystems, v. 9, Q08010, doi:10.1029/2008GC001974.

Groeneveld, J., Nürnberg, D., Tiedemann, R., Reichart, G. J., Steph, S., Reuning, L., Crudeli, D., and Mason, P., 2008, Foraminiferal $\mathrm{Mg} / \mathrm{Ca}$ increase in the Caribbean during the Pliocene: Western Atlantic warm pool formation, salinity influence, or diagenetic overprint?: Geochemistry, Geophyics, Geosystems, v. 9, Q01P23, doi:10.1029/2006GC001564.

Gutjahr, M., Frank, M., Stirling, C. H., Keigwin, L. D., and Halliday, A. N., 2008, Tracing the Nd isotope evolution of North Atlantic deep and intermediate waters in the western North Atlantic since the last glacial maximum from Blake Ridge sediments: Earth and Planetary Science Letters, v. 266, p. 61-77.

HANOR, J. S., and CHAN, L.-H., 1977, Non-conservative behavior of barium during mixing of Mississippi River and Gulf of Mexico waters: Earth and Planetary Science Letters, v. 37, p. 242-250. 
Hayes, J. M., Strauss, H., and Kaufman, A. J., 1999, The abundance of ${ }^{13} \mathrm{C}$ in marine organic matter and isotopic fractionation in the global biogeochemical cycle of carbon during the past $800 \mathrm{Ma}$ : Chemical Geology, v. 161, p. 103-125.

Hays, J. D., Imbrie, J., and Shackleton, N. J., 1976, Variations in the Earth's orbit: pacemaker of the ice ages: Science, v. 194, p. 1121-1132.

Healey, S. L., Thunell, R. C., and Corliss, B. H., 2008, The Mg/Catemperature relationship of benthic foraminiferal calcite: new core-top calibrations in the $<4^{\circ} \mathrm{C}$ temperature range: Earth and Planetary Science Letters, v. 272, p. 523-530.

Hecht, A. D., Eslinger, E. V., and Garmon, L. B., 1975, Experimental studies on the dissolution of planktonic foraminifera, in Sliter, W. V., Bè, A. W. H., and Berger, W. H. (eds.), Dissolution of Deep-Sea Carbonates. Cushman Foundation for Foraminiferal Research, Special Publication 13, p. 56-69.

Hemleben, C., Spindler, M., and Anderson, O. R., 1989, Modern Planktonic Foraminifera: Springer-Verlag, Berlin, 360 p.

Hemming, N. G., and Hanson, G. N., 1992, Boron isotopic composition and concentration in modern marine carbonates: Geochimica et Cosmochimica Acta, v. 56, p. 537-543.

Hendry, K. R., Rickaby, R. E. M., De Hoog, J. C. M., Weston, K., and REHKÄMPER, M., 2008, Cadmium and phosphate in coastal Antarctic seawater: implications for Southern Ocean nutrient cycling: Marine Chemistry, v. 112, p. 149-157.

HerguerA, J. C., 1992, Deep-sea benthic foraminifera and biogenic opal: glacial to postglacial productivity changes in the western equatorial Pacific: Marine Micropalaeontology, v. 19, p. 79-98.

Hess, J., Bender, M. L., and Schilling, J.-G., 1986, Evolution of the ratio of strontium- 87 to strontium-86 in seawater from Cretaceous to present: Science, v. 231, p. 979-984.

Hintz, C. J., Shaw, T. J., Bernhard, J. M., Chandler, G. T., McCorckle, D. C., and Blanks, J. K., 2006b, Trace/minor element:calcium ratios in cultured benthic foraminifera. Part II: Ontogenetic variation: Geochimica et Cosmochimica Acta, v. 70, p. 1964-1976.

- - Chandler, G. T., Bernhard, J. M., McCorckle, D. C., and Blanks, J. K., 2006a, Trace/minor element:calcium rations in cultured benthic foraminifera. Part I: Inter-species and inter-individual variability: Geochimica et Cosmochimica Acta, v. 70 , p. $1952-1963$.

Hodell, D. A., Kamenov, G. D., Hathorne, E. C., Zachos, J. C., Roehl, U., and Westerhold, T., 2007, Variations in the strontium isotope composition of seawater during the Paleocene and early Eocene from ODP Leg 208 (Walvis Ridge): Geochemistry, Geophysics, Geosystems, v. 8, Q09001, doi:09010.01029/ 02007GC001607.

- Mueller, P. A., and Garrido, J. R., 1991, Variations in the strontium isotope composition of seawater during the Neogene: Geology, v. 19, p. 24-27.

—, and WoodruFF, F., 1994, Variations in the strontium isotopic ratio of seawater during the Miocene: stratigraphic and geochemical implications: Paleoceanography, v. 9, p. 405-426.

Hönisch, B., Bickert, T., and Hemming, N. G., 2008, Modern and Pleistocene boron isotope composition of the benthic foraminifer Cibicidoides wuellerstorfi: Earth and Planetary Science Letters, v. 272 , p. $309-318$.

, Bijma, J., Russell, A. D., Spero, H. J., Palmer, M. R., Zeebe, R. E., and Eisenhauer, A., 2003, The influence of symbiont photosynthesis on the boron isotopic composition of foraminifera shells: Marine Micropaleontology, v. 49, p. 8796.

—, and Hemming, N. G., 2004, Ground-truthing the boron isotope paleo-pH proxy in planktonic foraminifera shells: partial dissolution and shell size effects: Paleoceanography, v. 19, Q08010, doi:10.1029/2004PA001026.

- and -2005 , Surface ocean $\mathrm{pH}$ response to variations in $\mathrm{pCO}_{2}$ through two full glacial cycles: Earth and Planetary Science Letters, v. 236, p. 305-314.

, evaluation of the boron isotope-pH proxy: The accuracy of ancient ocean $\mathrm{pH}$ estimates" by M. Pagani, D. Lemarchand, A. Spivack and J. Gaillardet: Geochimica et Cosmochimica Acta, v. 71, p. 1636-1641.
Howarth, R. J., and McArthUR, J. M., 1997, Statistics for strontium isotope stratigraphy: a robust LOWESS fit to the marine strontium isotope curve for the period 0 to $206 \mathrm{Ma}$, with lookup table for the derivation of numerical age: Journal of Geology, v. 105 , p. $441-456$.

Huang, K.-F., You, C.-F., Lin, H.-L., and Shieh, Y.-T., 2008, In situ calibration of $\mathrm{Mg} / \mathrm{Ca}$ ratio in planktonic foraminiferal shell using time series sediment trap: a case study of intense dissolution artifact in the South China Sea: Geochemistry, Geophysics, Geosystems, v. 9, Q04016, doi:10.1029/2007GC001660.

Huber, B. T., Norris, R. D., and MacLeod, K. G., 2002, Deep-sea paleotemperature record of extreme warmth during the Cretaceous: Geology, v. 30, p. 123-126.

Huybers, P., and Wunsch, C., 2004, A depth-derived Pleistocene age model: uncertainty estimates, sedimentation variability, and nonlinear climate change: Paleoceanography, v. 19, PA1028, doi:1010.1029/2002PA000857.

Imbrie, J., Berger, A., Boyle, E. A., Clemens, S. C., Duffy, A., Howard, W. R., Kukla, G., Kutzbach, J., Martinson, D. G., Mcintyre, A., Mix, A. C., Molfino, B., Morley, J. J., Peterson, L. C., Pisias, N. G., Prell, W. L., Raymo, M. E., Shackleton, N. J., and Toggweiler, J. R., 1993, On the structure and origin of major glaciation cycles: 2 . The 100,000year cycle: Paleoceanography, v. 8, p. 699-735.

-, Hays, J. D., Martinson, D. G., Mcintyre, A., Mix, A. C., Morley, J. J., Pisias, N. G., Prell, W. L., and Shackleton, N. J., 1984, The orbital theory of pleistocene climate: support from a revised chronology of the marine $\delta^{18} \mathrm{O}$ record, in Berger, A. L., Imbrie, J., Hays, J., Kukla, G., and Saltzman, B. (eds.), Milankovitch and Climate, Part 1: D. Reidel, Dordrecht, p. 269-305.

_, and KIPP, N. G., 1971, A new micropaleontological method quantitative paleoclimatology: Application to a late Pleistocene core., in Turekian, K. (ed.), The Late Cenozoic Ice Ages: Yale University Press, New Haven, p. 71-181.

Jorissen, F. J., Barmawidjaja, D. M., Puskaric, S., and van Der ZWAAN, G. J., 1992, Vertical distribution of benthic foraminifera in the northern Adriatic Sea; the relation with the organic flux: Marine Micropaleontology, v. 19, p. 1-2.

_, DE Stiger, H. C., and Widmark, J. G. V., 1995, A conceptual model explaining benthic foraminiferal microhabitats: Marine Micropaleontology, v. 26, p. 3-15.

KAIHO, K., 1999, Effect of organic carbon flux and dissolved oxygen on the benthic foraminiferal oxygen index (BFOI): Marine Micropaleontology, v. 37, p. 67-76.

Kakihana, H., Kotaka, M., Satoh, S., Nomura, M., and OKamoto, M., 1977, Fundamental studies on the ion-exchange of boron isotopes: Bulletin of the Chemical Society of Japan, v. 50, p. $158-163$.

Katz, M. E., Katz, D. R., Wright, J. D., Miller, K. G., PaK, D. K., Shackleton, N. J., and Thomas, E., 2003a, Early Cenozoic benthic foraminiferal isotopes: species reliability and interspecies correction factors: Paleoceanography, v. 18, 1024, doi:10.1029/ 2002PA000798.

, and Miller, K. G., 1993, Latest Oligocene to Pliocene benthic foraminiferal biofacies of northeastern Gulf of Mexico: Micropaleontology, v. 39, p. 367-403.

- Wright, J. D., Wade, B., Browning, J. V., Cramer, B. S., and Rosenthal, Y., 2008, Stepwise transition from the Eocene greenhouse to the Oligocene icehouse: Nature Geoscience, v. 1 , p. $329-334$.

, TJalsma, R. C., and Miller, K. G., 2003b, Oligocene bathyal to abyssal benthic foraminifera of the Atlantic Ocean: Micropaleontology, v. 49, p. 1-45.

—, Wright, J. D., Miller, K. G., Cramer, B. S., Fennel, K., and Falkowski, P. G., 2005, Biological overprint of the geological carbon cycle: Marine Geology, v. 217, p. 323-338.

Kennett, J. P., Keller, G., and Srinivasan, M. S., 1985, Miocene planktonic foraminiferal biogeography and paleoceanographic development of the Indo-Pacific region, in Kennett, J. P. (ed.), The Miocene Ocean: Paleoceanography and Biogeography: Geological Society of America Memoir, v. 163, p. 197-236.

Kisakurek, B., Eisenhauer, A., Böhm, F., Garbe-Schönberg, D., and EreZ, J., 2008, Controls on shell $\mathrm{Mg} / \mathrm{Ca}$ and $\mathrm{Sr} / \mathrm{Ca}$ in cultured 
planktonic foraminiferan, Globigerinoides ruber (white): Earth and Planetary Science Letters, v. 273, p. 260-269.

KLevenZ, V., 2008, Neodymium isotopes in benthic foraminifera: coretop systematics and a down-core record from the Neogene South Atlantic: Earth and Planetary Science Letters, v. 265, p. 571-587.

Klochko, K., Kaufman, A. J., Yao, W., Byrne, R. H., and Tossell, J. A., 2006, Experimental measurement of boron isotope fractionation in seawater: Earth and Planetary Science Letters, v. 248 , p. $261-270$.

Kominz, M. A., and Pisias, N. G., 1979, Pleistocene climate: deterministic or stochastic: Science, v. 204, p. 171-173.

Kroopnick, P. M., 1974, The dissolved $\mathrm{O}_{2}-\mathrm{CO}_{2}-{ }^{13} \mathrm{C}$ system in the eastern equatorial Pacific: Deep Sea Research, v. 21, p. 211-227. - 1985, The distribution of C-13 in the world oceans: Deep Sea Research, v. 32, p. 57-84.

Kump, L. R., and Arthur, M. A., 1999, Interpreting carbon-isotope excursions: carbonates and organic matter: Chemical Geology, v. 161, p. $181-198$.

LEA, D. W., 1990, Foraminiferal and coralline barium as paleoceanographic tracers: Unpublished Ph.D. Dissertation, Massachusetts Institute of Technology/Woods Hole Oceanographic Institution.

- 1993, Constraints on the alkalinity and circulation of glacial circum polar deep water from benthic foraminiferal barium: Global Biogeochemical Cycles, v. 7, p. 695-710.

-1995 , A trace-metal perspective on the evolution of Antarctic circumpolar deep-water chemistry: Paleoceanography, v. 10, p. 733-747.

, and BoyLe, E., 1989, Barium content of benthic foraminifera controlled by bottom water composition: Nature, v. 338, p. $751-753$.

, and _ 1990, Foraminiferal reconstructions of barium distributions in water masses of the glacial oceans: Paleoceanography, v. 5, p. 719-742.

, and - 1991, Barium in planktonic foraminifera: Geochimica et Cosmochimica Acta, v. 55, p. 3321-3331.

, and SPERo, H. J., 1992, Experimental determination of barium uptake in shells of the planktonic foraminifera Orbulina universa at $22^{\circ} \mathrm{C}$ : Geochimica et Cosmochimica Acta, v. 56, p. 2673-2680. , and — 1994, Assessing the reliability of paleochemical tracers: barium uptake in the shells of planktonic foraminifera: Paleoceanography, v. 9, p. 445-452.

—, Mashiotta, T. A., and Spero, H. J., 1999, Controls on magnesium and strontium uptake in planktonic foraminifera determined by live culturing: Geochimica et Cosmochimica Acta, v. 63, p. 2369-2379.

, PAK, D. K., and Spero, H. J., 2000, Climate impact of late Quaternary equatorial Pacific sea surface temperature variations: Science, v. 289, p. 1719-1724.

and PARADIS, G., 2005, Influence of volcanic shards on foraminiferal $\mathrm{Mg} / \mathrm{Ca}$ in a core from the Galapagos region: Geochemistry, Geophysics, Geosystems, v. 6, Q11P04, doi:10.1029/ 2005GC000970.

Lear, C., 2003, A Cenozoic seawater $\mathrm{Sr} / \mathrm{Ca}$ record from benthic foraminiferal calcite and its application in determining global weathering fluxes: Earth and Planetary Science Letters, v. 208, p. $69-84$

, Elderfield, H., and Wilson, P. A., 2000, Cenozoic deep-sea temperatures and global ice volumes from $\mathrm{Mg} / \mathrm{Ca}$ in benthic foraminiferal calcite: Science, v. 287, p. 269-272.

, Rosenthal, Y., and Slowey, N., 2002, Benthic foraminiferal $\mathrm{Mg} / \mathrm{Ca}$-paleothermometry: A revised core-top calibration: Geochimica Cosmochimica Acta, v. 66, p. 3375-3387.

, Coxall, H. K., and Wilson, P. A., 2004, Late Eocene to early Miocene ice sheet dynamics and the global carbon cycle: Paleoceanography, v. 19, PA4015, doi:10.1029/2004PA001039.

Levitus, S., and BOYER, T. P., 1994, World ocean atlas 1994, volume 4: temperature: NOAA Atlas NESDIS v. 4: Government Printing Office, Washington, D.C., 117 p.

Lisiecki, L. E., and RAYmo, M. E., 2005, A Pliocene-Pleistocene stack of 57 globally distributed benthic O records: Paleoceanography, v. 20, PA1003, doi:10.1029/2004PA001071.

Lohmann, G. P., 1978, Abyssal benthonic foraminifera as hydrographic indicators in the western South Atlantic: Journal of Foraminiferal Research, v. 8, p. 6-34.
1995, A model for variation in the chemistry of planktonic foraminifera due to secondary calcification and selective dissolution: Paleoceanography, v. 10, p. 445-457.

Lorens, R. B., Williams, D. F., and Bender, M. L., 1977, The early nonstructural chemical diagenesis of foraminiferal calcite: Journal of Sedimentary Petrology, v. 47, p. 1602-1609.

Loubere, P., 1994, Quantitative estimation of surface ocean productivity and bottom water oxygen concentration using benthic foraminifera: Paleoceanography, v. 9, p. 723-116.

-, and FARIDDUDIN, M., 1999, Quantitative estimation of global patterns of surface ocean biological productivity and its seasonal variation on timescales from centuries to millennia: Global Biochemical Cycles, v. 13, p. 115-133.

Lutze, G. F., 1978, Neogene benthonic foraminifera from Site 369 , Leg 41, Deep Sea Drilling Project, in Lancelot, Y., Seibold, E., and others. (eds.), Initial Reports of the Deep Sea Drilling Project, v. 41: U.S. Government Printing Office, Washington, D.C., p. $659-666$.

Lynch-Stieglitz, J., and Fairbanks, R. G., 1994, A conservative tracer for glacial ocean circulation from carbon isotope and paleonutrient measurements in benthic foraminifera: Nature, v. 369, p. 308-310.

Mackensen, A., Fuetterer, D., Grobe, H., and Schmiedl, G., 1993a, Benthic foraminiferal assemblages from the eastern South Atlantic polar front region between $35^{\circ}$ and $57^{\circ} \mathrm{S}$ : distribution, ecology and fossilization potential: Marine Micropaleontology, v. 22 , p. $33-69$.

-, Hubberten, H.-W., Bickert, T., Fischer, G., and FutTERER, D. K., 1993b, The $\delta^{13} \mathrm{C}$ record in benthic formainiferal tests of Fontbotia wuellerstorfi (Schwager) relative to the $\delta^{13} \mathrm{C}$ of dissolved inorganic carbon in Southern Ocean deepwater: implications for glacial ocean circulation models: Paleoceanography, v. 8, p. 587-610.

MacLeod, K. G., Huber, B. T., and Isaza-Londono, C., 2005, North Atlantic warming during "global" cooling at the end of the Cretaceous: Geology, v. 33, p. 437-440.

Marchitto, T. M., 2004, Lack of a significant temperature influence on the incorporation of $\mathrm{Cd}$ into benthic foraminiferal tests: Geochemistry, Geophysics, Geosystems, v. 5, Q10D11, doi:10.1029/2004GC000753.

— and Broecker, W. S., 2006, Deep water mass geometry in the glacial Atlantic Ocean: a review of constraints from the paleonutrient proxy Cd/Ca: Geochemistry, Geophysics, Geosystems, v. 7, Q12003, doi:10.1029/2006GC001323.

, Curry, W. B., and OPPo, D. W., 2000, Zinc concentrations in benthic foraminifera reflect seawater chemistry: Paleoceanography, v. 15 , p. $299-306$.

, Lynch-Stieglitz, J., and Hemming, S. R., 2005, Deep Pacific $\mathrm{CaCO}_{3}$ compensation and glacial-interglacial atmospheric $\mathrm{CO}_{2}$ : Earth and Planetary Science Letters, v. 231, p. 317-336.

-, Bryan, S. P., Curry, W. B., and McCorkle, D. C., 2007, $\mathrm{Mg} / \mathrm{Ca}$ temperature calibration for the benthic foraminifer Cibicidoides pachyderma: Paleoceanography, v. 22, p. 1-9.

Martin, P. A., Lea, D. W., Rosenthal, Y., Papenfuss, T. P., and SARNTHEIN, M., 2002, Late Quaternary deep-sea temperatures inferred from benthic foraminiferal magnesium: Earth and Planetary Science Letters, v. 198, p. 193-209.

Martinson, D. G., Pisias, N. G., Hays, J. D., Imbrie, J., Moore, T. C., JR., and Shackleton, N. J., 1987, Age dating and the orbital theory of the ice ages: Development of a high-resolution 0 to 300,000-year chronostratigraphy: Quaternary Research, v. 27, p. 1-29.

Mashiotta, T. A., Lea, D. W., and Spero, H. J., 1999, Glacialinterglacial changes in subantarctic sea surface temperature and $\delta^{18} \mathrm{O}$-water using foraminiferal $\mathrm{Mg}$ : Earth and Planetary Science Letters, v. 170, p. 417-432.

McConnell, M. C., and Thunell, R. C., 2005, Calibration of the planktonic foraminiferal $\mathrm{Mg} / \mathrm{Ca}$ paleothermometer: sediment trap results from the Guaymas basin, Gulf of California: Paleoceanography, v. 20, PA2016, doi:10.1029/2004PA001077.

McCorckle, D. C., Keigwin, L. D., Corliss, B. H., and Emerson, S. R., 1990, The influence of microhabitats on the carbon isotopic composition of deep sea benthic foraminifera: Paleoceanography, v. 5 , p. $161-186$. 
, Martin, P. A., Lea, D. W., and Klinkhammer, G. P., 1995, Evidence of a dissolution effect on benthic foraminiferal shell chemistry $-\delta^{13} \mathrm{C}, \mathrm{Cd} / \mathrm{Ca}, \mathrm{Ba} / \mathrm{Ca}$, and $\mathrm{Sr} / \mathrm{Ca}$ Results from the Ontong Java Plateau: Paleoceanography, v. 10, p. 699-714.

—, Bernhard, J. M., Hintz, C. J., Blank, J. K., Chandler, G. T., and SHAw, T. J., 2008, The carbon and oxygen stable isotopic composition of cultured benthic foraminifera, in Austin, W. E. N., and James, R. H. (eds.), Biogeochemical Controls on Palaeoceanographic Environmental Proxies: Geological Society, London, Special Publications, v. 303, p. 135-154.

McKenzie, J. A., Hodell, D. A., Mueller, P. A., and Mueller, D. W., 1988, Application of $\mathrm{Sr}$ isotopes to late Miocene-early Pliocene stratigraphy: Geology, v. 16, p. 1022-1025.

McNeil, D. H., and Miller, K. G., 1990, Sr isotope and benthic foraminiferal correlations of Arctic strata (Nuwok Beds, Alaskan North Slope) to standard Oligocene chronostratigraphy: Geology, V. 18, p. $415-418$.

Miller, K. G., and Katz, M. E., 1987, Oligocene-Miocene benthic foraminiferal and abyssal circulation changes in the North Atlantic: Micropaleontology, v. 33, p. 97-149.

—, and LohmanN, G. P., 1982, Environmental distribution of Recent benthic foraminifera on the northeast United States continental slope: Geological Society of America Bulletin, v. 93, p. 200-206.

—, Fairbanks, R. G., and Mountain, G. S., 1987, Tertiary oxygen isotope synthesis, sea level history, and continental margin erosion: Paleoceanography, v. 2, p. 1-19.

- Feigenson, M. D., Kent, D. V., and Olsson, R. K., 1988, Oligocene stable isotope $\left({ }^{87} \mathrm{Sr} /{ }^{86} \mathrm{Sr}, \delta^{18} \mathrm{O}, \delta^{13} \mathrm{C}\right)$ standard section, Deep Sea Drilling Project Site 522: Paleoceanography, v. 3, p. $223-233$.

— Wright, J. D., and Clement, B. M., 1991a, Miocene isotope reference section, Deep Sea Drilling Project Site 608: an evaluation of isotope and biostratigraphic resolution: Paleoceanography, v. 6, p. $33-52$.

, , and Fairbanks, R. G., 1991b, Unlocking the ice house: Oligocene-Miocene oxygen isotopes, eustasy, and margin erosion: Journal of Geophysical Research, v. 96, p. 6829-6848.

, Kominz, M. A., Browning, J. V., Wright, J. D., Mountain, G. S., Katz, M. E., Sugarman, P. J., Cramer, B. S., ChristieBlick, N., and Pekar, S. F., 2005, The Phanerozoic record of global sea-level change: Science, v. 310, p. 1293-1298.

- Browning, J. V., Aubry, M.-P., Wade, B., Katz, M. E., Kulpecz, A. A., and Wright, J. D., 2008, Eocene-Oligocene global climate and sea-level changes: St. Stephens Quarry, Alabama: Geological Society of America Bulletin, v. 12, p. 34-53.

Min, G. R., Edwards, R. L., Taylor, F. W., Recy, J., Gallup, C. D., and BECK, J. W., 1995, Annual cycles of U/Ca in coral skeletons and U/Ca thermometry: Geochimica et Cosmochimica Acta, v. 59, p. 2025-2042.

Mix, A. C., Ruddiman, W. F., and McIntyre, A., 1986, Late Quaternary paleoceanography of the tropical Atlantic, I: Spatial variability of annual mean sea-surface temperatures, 0 20,000 years B.P.: Paleoceanography, v. 1, p. 43-66.

- Morey, A. E., Pisias, N. G., and Hostetler, S. W., 1999, Foraminiferal faunal estimates of paleotemperature: circumventing the no-analogue problem yields cool ice age tropics: Paleoceanography, v. 14 , p. $350-359$.

Mohtadi, M., Steinke, S., Groeneveld, J., Fink, H. G., Rixen, T., Hebbeln, D., Donner, B., and Herunadi, B., 2009, Lowlatitude control on seasonal and interannual changes in planktonic foraminiferal flux and shell geochemistry off south Java: a sediment trap study: Paleoceanography, v. 24, PA1201, doi:10.1029/2008PA001636.

Morigi, C., Jorissen, F. J., Gervais, A., Guichard, S., and BorsetTI, A. M., 2001, Benthic foraminiferal faunas in surface sediments off NW Africa: relationship with organic flux to the ocean floor: Journal of Foraminiferal Research, v. 31, p. 350-368.

Moy, A. D., Howard, W. R., Bray, S. G., and Trull, T. W., 2009, Reduced calcification in modern Southern Ocean planktonic foraminifera: Nature Geoscience, v. 2, p. 276-280.

Murray, J. W., 1984, Paleogene and Neogene benthic foraminifera from Rockall Plateau, in Roberts, D. G., Schnitker, D., and others. (eds.), Initial Reports of the Deep Sea Drilling Project, v.
81: U.S. Government Printing Office, Washington, D.C., p. $503-534$.

- 1995, Microfossil indicators of ocean water masses, circulation and climate, in Bosence, D. W. J., and Allison, P. A. (eds.), Marine Palaeoenvironmental Analysis from Fossils. Geological Society, London, Special Publication 83, p. 245-264.

Ni, Y., Foster, G. L., Bailey, T., Elliott, T., Schmidt, D. N., Pearson, P. N., Haley, B., and Coath, C., 2007, A core top assessment of proxies for the ocean carbonate system in surface-dwelling foraminifers: Paleoceanography, v. 22, PA3212, doi:10.1029/2006PA001337.

NürNBERG, D., 1995, Magnesium in tests of Neogloboquadrina pachyderma sinistral from high northern and southern latitudes: Journal of Foraminiferal Research, v. 25, p. 350-368.

_ Bijma, J., and Hemleben, C., 1996, Assessing the reliability of magnesium in foraminiferal calcite as a proxy for water mass temperature: Geochimica et Cosmochimica Acta, v. 60, p. 803-814.

O’Neil, J. R., Clayton, R. N., and Mayeda, T. K., 1969, Oxygen isotope fractionation in divalent metal carbonates: Journal of Chemical Physics, v. 51, p. 5547-5558.

Oppo, D. W., and FAIRBANKS, R. G., 1987, Variability in the deep and intermediate water circulation of the Atlantic Ocean during the past 25,000 years: northern hemisphere modulation of the Southern Ocean: Earth and Planetary Science Letters, v. 86, p. $1-15$.

- and $\longrightarrow, 1989$, Carbon isotope composition of tropical surface water during the past 22,000 years: Paleoceanography, v. 4, p. 333-352.

Ortner, P. B., Wiebe, P. H., and Cox, J. L., 1980, Relationship between oceanic epizooplankton distributions and seasonal deep chlorophyll maximum in the northwestern Atlantic Ocean: Journal of Marine Research, v. 38, p. 507-531.

Oslick, J. F., Miller, K. M., Feigenson, M. D., and Wright, J. D., 1994, Testing Oligocene-Miocene strontium isotopic correlations: relationships with an inferred glacioeustatic record: Paleoceanography, v. 9, p. 427-443.

Pälike, H., Frazier, J., and Zachos, J. C., 2006, Extended orbitally forced palaeoclimatic records from the equatorial Atlantic Ceara Rise: Quaternary Science Reviews, v. 25, p. 3138-3149.

- Norris, R. D., Herrle, J. O., Wilson, P. A., Coxall, H. K., Lear, C. A., Shackelton, N. J., Tripati, A. K., and Wade, B. S., 2006, The heartbeat of the Oligocene climate system: Science, v. 314 , p. $1894-1898$.

Palmer, M. R., and Pearson, P. N., 2003, A 23,000-year record of surface water $\mathrm{pH}$ and $\mathrm{pCO}_{2}$ in the western equatorial Pacific Ocean: Science, v. 300, p. 480-482.

Pearson, P. N., Ditchfield, P. W., Singano, J., Harcourt-Brown, K. G., Nicholas, C. J., Olsson, R. N., Shackleton, N. J., and HaLl, M. A., 2001, Warm tropical sea surface temperatures in the Late Cretaceous and Eocene epochs: Nature, v. 413, p. 481-487.

- , and Palmer, J. D., 2000, Atmospheric carbon dioxide concentrations over the past 60 million years: Nature, v. 406, p. 695-699.

Pekar, S., and Miller, K. G., 1996, New Jersey Oligocene "icehouse" sequences (ODP Leg 150X) correlated with global $\mathrm{d}^{18} \mathrm{O}$ and Exxon eustatic records: Geology, v. 24, p. 567-570.

—, Christie-Blick, N., Kominz, M. A., and Miller, K. G., 2002, Calibration between eustatic estimates from backstripping and oxygen isotopic records for the Oligocene: Geology, v. 30, p. 903-906.

Pena, L. D., Calvo, E., Cacho, I., Eggins, S., and Pelejero, C., 2005, Identification and removal of Mn-Mg-rich contaminant phases on foraminiferal tests: Implications for $\mathrm{Mg} / \mathrm{Ca}$ past temperature reconstructions: Geochemistry, Geophysics, Geosystems, v. 6, Q09P02, doi:10.1029/2005GC000930.

—- Cacho, I., Calvo, E., Pelejero, C., Eggins, S., and SADEKov, A., 2008, Characterization of contaminant phases in foraminifera carbonates by electron microprobe mapping: Geochemistry, Geophysics, Geosystems, v. 9, Q07012, doi:10.1029/ 2008GC002018.

Piotrowski, A. M., Banakar, V. K., Scrivner, A. E., Elderfield, H., and GALY, A., 2009, Indian Ocean circulation and productiv- 
ity during the last glacial cycle: Earth and Planetary Science Letters, v. 285, p. 179-189.

-, Goldstein, S. L., Hemming, S. R., and Fairbanks, R. G., 2005. Temporal relationships of carbon cycling and ocean circulation at glacial boundaries: Science, v. 307, p. 1933-1937.

Pogge von Strandmann, P. A. E., 2008, Precise magnesium isotope measurements in core top planktic and benthic foraminifera: Geochemistry, Geophysics, Geosystems, v. 9, Q12015, doi: 12010.11029/12008GC002209.

Poore, H. R., Samworth, R., White, N. J., Jones, S. M., and McCAve, I. N., 2006, Neogene overflow of northern component water at the Greenland-Scotland ridge: Geochemistry, Geophysics, Geosystems, v. 7, Q06010, doi:10.1029/2005GC001085.

Rathburn, A. E., and Corliss, B. H., 1994, The ecology of deep-sea benthic foraminifera from the Sulu Sea: Paleoceanography, v. 9, p. $87-150$.

Ravelo, A. C., and Fairbanks, R. G., 1992, Oxygen isotopic composition of multiple species of planktonic foraminifera: Recorders of the modern photic zone temperature gradient: Paleoceanography, v. 7, p. 815-831.

Ravizza, G., 1993, Variations of the ${ }^{187} \mathrm{Os} /{ }^{186} \mathrm{Os}$ ratio of seawater over the past 28 million years as inferred from metalliferous carbonates: Earth and Planetary Science Letters, v. 118 , p. $335-348$.

Regenberg, M., Nürnberg, D., Steph, S. G. J., Garbe-SchönberG, D., and Tiedemann, R., 2006, Assessing the effect of dissolution on planktonic foraminiferal $\mathrm{Mg} / \mathrm{Ca}$ ratios: evidence from Caribbean core tops: Geochemistry, Geophysics, Geosystems, v. 7, Q07P15, doi:10.1029/2005GC001019.

, Steph, S., Nuernberg, N., Tiedemann, R., and GarbeSCHÖNBERG, D., 2009, Calibrating $\mathrm{Mg} / \mathrm{Ca}$ ratios of multiple planktonic foraminiferal species with $\mathrm{d}^{18} \mathrm{O}$-calcification temperatures: paleothermometry for the upper water column: Earth and Planetary Science Letters, v. 278, p. 324-336.

Reilly, T. J., Miller, K. G., and Feigenson, M. D., 2002, Late Eocene to Oligocene Sr-isotopic reference section, Site 522, eastern South Atlantic: Paleoceanography, v. 17, 1046, doi:10.1029/ 2001PA000745.

Reynaud, S., Hemming, N. G., Juillet-Leclerc, A., and Gattuso, J.-P., 2004, Effect of $\mathrm{pCO}_{2}$ and temperature on the boron isotopic composition of a zooxanthellate coral: Acropora sp.: Coral Reefs, v. 23, p. $539-546$.

Reynolds, L. A., 1986, Seasonal production and morphologic variation of Neogloboquadrina pachyderma (Ehrenberg) in the Northeast Pacific: Micropaleontology, v. 32, p. 1-18.

- and Thunell, R. C., 1985, Seasonal succession of planktonic foraminifera in the subpolar North Pacific: Journal of Foraminiferal Research, v. 15, p. 282-301.

Rickaby, R., and Elderfield, H., 1999, Planktonic Cd/Ca: paleonutrients or paleotemperature: Paleoceanography, v. 14, p. 293-303.

RipPerger, S., Schiebel, R., RehKämPer, M., and Halliday, A. N., 2008, Cd/Ca ratios of in situ collected planktonic foraminiferal tests: Paleoceanography, v. 23, PA3209, doi:10.1029/ 2007PA001524.

Rosenthal, Y., 1994, Late Quaternary Paleochemistry of the Southern Ocean: Evidence from Cadmium Variability in Foraminifera and Sediments: Unpublished Ph.D. Dissertation, Massachusetts Institute of Technology/Woods Hole Oceanographic Institution.

- 1997b, Temperature control on the incorporation of Mg, Sr, F and $\mathrm{Cd}$ into benthic foraminiferal shells from Little Bahama Bank: prospects for thermocline paleoceanography: Geochimica et Cosmochimica Acta, v. 61, p. 3633-3643.

- and Boyle, E. A., 1993, Factors controlling the fluoride content of planktonic foraminifera: an evaluation of its paleoceanographic applicability: Geochimica et Cosmochimica Acta, v. 57, p. $335-346$

- and LohmanN, G. P., 2002, Accurate estimation of sea surface temperatures using dissolution-corrected calibrations for $\mathrm{Mg} / \mathrm{Ca}$ paleothermometry: Paleoceanography, v. 17, 1044, doi:10.1029/ 2001PA000749.

- BOYLE, E. A., LABEYRIE, L, and OpPO, D., 1995a, Glacia enrichments of authigenic $\mathrm{Cd}$ and $\mathrm{U}$ in sub-Antarctic sediments a climatic control on the elements oceanic budget: Paleoceanography, v. 10 , p. $395-413$.
—_, Lam, P., Boyle, E. A., and Thomson, J., 1995b, Authigenic cadmium: precipitation and post-depositional remobilization: Earth and Planetary Science Letters, v. 132, p. 99-111.

- Boyle, E. A., and Slowey, N., 1997a, Environmental controls on the incorporation of $\mathrm{Mg}, \mathrm{Sr}, \mathrm{F}$ and $\mathrm{Cd}$ into benthic foraminiferal shells from Little Bahama Bank: prospects for thermocline paleoceanography: Geochimica et Cosmochimica Acta, v. 61, p. 3633-3643.

, Lohmann, G. P., Lohmann, K. C., and Sherrell, R. M. 2000a, Incorporation and preservation of $\mathrm{Mg}$ in Gs. sacculifer: implications for reconstructing sea surface temperatures and the oxygen isotopic composition of seawater: Paleoceanography, v. 15, p. 135-145.

-, Stoll, H., Wyman, K., and Falkowski, P., 2000b, Growth related variations in carbon isotopic fractionation and coccoliths chemistry in Emiliania huxeleyii: AGU Ocean Sciences Meeting, San Antonio Texas, Abstract OS51A-05.

- Perron-Cashman, S., Lear, C. H., Bard, E., Barker, S., Billups, K., Bryan, M., Delaney, M. L., DeMenocal, P. B., Dwyer, G. S., Elderfield, H., German, C. R., Greaves, M., Lea, D. W., Marchitto Jr.T. M., Pak, D. P., Paradis, G. L., Russell, A. D., Schneider, R. R., Scheindrich, K., Stott, L., Tachikawa, K., TAPpa, E., Thunell, R., Wara, M., Weldeab, S., and Wilson, P. A., 2004, Laboratory inter-comparison study of $\mathrm{Mg} / \mathrm{Ca}$ and $\mathrm{Sr} / \mathrm{Ca}$ measurements in planktonic foraminifera for paleoceanographic research: Geophysics, Geochemistry, Geosystems, v. 5, Q04D09, doi:10.1029/2003GC000650.

- Lear, C. H., Oppo, D. W., and Linsley, B. K., 2006, Temperature and carbonate ion effects on $\mathrm{Mg} / \mathrm{Ca}$ and $\mathrm{Sr} / \mathrm{Ca}$ ratios in benthic foraminifera: the aragonitic species Hoeglundina elegans: Paleoceanography, v. 21, PA1007, doi:10.1029/2005PA001158.

Rubin, S. I., King, S. L., Jahnke, R. A., and Froelich, P. N., 2003, Benthic barium and alkalinity fluxes: Is $\mathrm{Ba}$ an oceanic paleoalkalinity proxy for glacial atmospheric $\mathrm{CO}_{2}$ ?: Geophysical Research Letters, v. 30, p. 1885.

Russell, A. D., Emerson, S., Nelson, B., Erez, J., and Lea, D. W., 1994, Uranium in foraminiferal calcite as a recorder of seawater uranium concentrations: Geochimica et Cosmochimica Acta, v. 58, p. 671-681.

—, Emerson, S., Mix, A. C., and Peterson, L. C., 1996, The use of foraminiferal uranium/calcium ratios as an indicator of changes in seawater uranium content: Paleoceanography, v. 11, p. 649-663.

- Hoenisch, B., Spero, H. J., and Lea, D. W., 2004, Effects of seawater carbonate ion concentration and temperature on shell $\mathrm{U}$, $\mathrm{Mg}$, and $\mathrm{Sr}$ in cultured planktonic foraminifera: Geochimica et Cosmochimica Acta, v. 68, p. 4347-4361.

Rutberg, R. L., Hemming, S. R., and Goldstein, S. L., 2000, Reduced North Atlantic Deep Water flux to the glacial Southern Ocean inferred from neodymium isotope ratios: Nature, v. 405, p. $935-938$.

Rutherford, S., D’Hondt, S., and Prell, W., 1999, Environmental controls on the geographic distribution of zooplankton diversity: Nature, v. 400, p. 749-753.

SANYAL, A., and BiJMA, J., 1999, A comparative study of the northwest Africa and eastern equatorial Pacific upwelling zones as sources of $\mathrm{CO}_{2}$ during glacial periods based on boron isotope paleo-pH estimation: Paleoceanography, v. 14, p. 753-759.

- and Nugent, M., 2000, Seawater pH control on the boron isotopic composition of calcite: evidence from inorganic calcite precipitation experiments: Geochimica et Cosmochimca Acta, v. 64 , p. $1551-1555$

-, Hemming, N. G., Hanson, G. N., and Broecker, W. S., 1995, Evidence for a higher $\mathrm{pH}$ in the glacial ocean from boron isotopes in foraminifera: Nature, v. 373, p. 234-236.

—, Hemming, N. G., Broecker, W. S., Lea, D. W., Spero, H. J., and HAnson, G. N., 1996, Oceanic pH control on the boron isotopic composition of foraminifera: Evidence from culture experiments: Paleoceanography, v. 11, p. 513-517.

- Hemming, N. G., Broecker, W. S., and Hanson, G. N., 1997, Changes in $\mathrm{pH}$ in the eastern equatorial Pacific across stage 5-6 boundary based on boron isotopes in foraminifera: Global Biogeochemical Cycles, v. 11, p. 125-133. 
, Bijma, J., Spero, H., and LeA, D. W., 2001, Empirical relationship between $\mathrm{pH}$ and the boron isotopic composition of Globigerinoides sacculifer: implications for the boron isotope paleo-pH proxy: Paleoceanography, v. 16, p. 515-519.

Saraswati, P. K., Seto, K., and Nomura, R., 2004, Oxygen and carbon isotopic variation in co-existing larger foraminifera from Reef flat at Akajima, Okinawa, Japan: Micropaleontology, v. 50, p. 339-349.

SAutter, L. R., and Thunell, R. C., 1989, Seasonal succession of planktonic foraminifera: results from a four-year time-series sediment trap experiment in the northeast Pacific: Journal of Foraminiferal Research, v. 19, p. 253-267.

SAvin, S. M., and Douglas, R. G., 1973, Stable isotope and magnesium geochemistry of Recent planktonic foraminifera from the South Pacific: Geological Society of America Bulletin, v. 84, p. 2327-2342. , and STEHLI, F. G., 1975, Tertiary marine paleotemperatures: Geological Society of America Bulletin, v. 86, p. 1499-1510.

Schmiedl, G., and Mackensen, A., 1997, Late Quaternary paleoproductivity and deep water circulation in the eastern South Atlantic Ocean: evidence from benthic foraminifera: Palaeogeography, Palaeoclimatology, Palaeoecology, v. 130, p. 43-80.

- - , and Muller, P. J., 1997, Recent benthic foraminifera from the eastern South Atlantic Ocean: dependence on food supply and water masses: Marine Micropaleontology, v. 32, p. 249-287.

, de Bovee, F., Buscail, R., Charriere, B., Hemleben, C., Medernach, L., and Picon, P., 2000, Trophic control of benthic foraminireal abundance and microhabitat in the bathyal Gulf of Lions, western Mediterranean Sea: Marine Micropaleontology, V. 40 , p. $167-188$.

SCHNITKER, D., 1974, West Atlantic abyssal circulation during the past 120,000 years: Nature, v. 248, p. 385-387.

- 1979, Cenozoic deep water foraminifers, Bay of Biscay, in Montadert, L., Roberts, D. G., and others. (eds.), Initial Reports of the Deep Sea Drilling Project, v. 48: U.S. Government Printing Office, Washington, D.C., p. 377-413.

Sexton, P. F., Wilson, P. A., and Pearson, P. N., 2006, Microstructural and geochemical perspectives on planktic foraminiferal preservation: "glassy" versus "frosty": Geochemistry, Geophysics, Geosystems, v. 7, p. 1-29.

Shackleton, N. J., 1974, Attainment of isotopic equilibrium between ocean water and the benthonic foraminifera genus Uvigerina: isotopic changes in the ocean during the last glacial: Colloques Internationaux du Centre National de la Recherche Scientifique, v. 219, p. 203-225.

- 2000, The 100,000-year ice-age cycle identified and found to lag temperature, carbon dioxide, and orbital eccentricity: Science, v. 289, p. 1897-1902.

, and Kennett, J. P., 1975, Paleotemperature history of the Cenozoic and the initiation of Antarctic glaciation, oxygen and carbon isotope analyses in DSDP sites 277, 279, and 281, in Kennett, J. P., Houtz, R. E., and others. (eds.), Initial Reports of the Deep Sea Drilling Project, v. 29: U.S. Government Printing Office, Washington, D.C., p. 743-755.

—, Berger, A. L., and Peltier, W. R., 1990, An alternative astronomical calibration of the lower Pleistocene timescale based on ODP Site 677: Transactions of the Royal Society of Edinburgh: Earth Sciences, v. 81, p. 251-261.

Shen, G. T., and Dunbar, R. B., 1995, Environmental controls on uranium in reef corals: Geochimica et Cosmochimica Acta, v. 59, p. 2009-2024.

Shevenell, A. E., Kennett, J. P., and LeA, D. W., 2004, Middle Miocene Southern Ocean cooling and Antarctic cryosphere expansion: Science, v. 305, p. 1766-1770.

Smart, C. W., King, S. C., Gooday, A. J., Murray, J. W., and Thomas, E., 1994, A benthic foraminiferal proxy of pulsed organic matter paleofluxes: Marine Micropaleontology, v. 23, p. 89-99.

Spero, H. J., and LEA, D. W., 1993, Intraspecific stable isotope variability in the planktic foraminifera Globigerinoides sacculifer: results from laboratory experiments: Marine Micropaleontology, v. 22, p. 221-234.

- and - 1996, Experimental determination of intraspecific stable isotope variability in Globigerina bulloides: implications for paleoceanographic reconstructions: Marine Micropaleontology, v. 28, p. 231-246.

- Lerche, I., and Williams, D. F., 1991, Opening the carbon isotope "vital effect" black box, 2, Quantitative model for interpreting foraminiferal carbon isotope data: Paleoceanography, v. 6, p. 639-655.

, Bijma, J., LeA, D. W., and Bemis, B. E., 1997, Effect of seawater carbonate concentration on foraminiferal carbon and oxygen isotopes: Nature, v. 390, p. 497-500.

-, -, and Russell, A. D., 1999, Deconvolving glacial ocean carbonate chemistry from the planktonic foraminifera carbon isotope record, in Abrantes, F., and Mix, A. (eds.), Reconstructing Ocean History: A Window Into the Future Plenum, New York, p. 329-342.

- Mielke, K. M., Kalve, E. M., Lea, D. W., and Pak, D. K., 2003, Multispecies approach to reconstructing eastern equatorial Pacific thermocline hydrography during the past 360 kyr: Paleoceanography, v. 18, 1022, doi:10.1029/2002PA000814.

Spivack, A. J., and Edmond, J. M., 1987, Boron isotope exchange between seawater and the oceanic crust: Geochimica et Cosmochimica Acta, v. 51, p. 1033-1043.

Steinke, S., Chiu, H.-Y., Yu, P.-S., Shen, C.-C., Lowemark, L., Mit, H.-S., and CHEN, M.-T., 2005, Mg/Ca ratios of two Globigerinoides ruber (white) morphotypes: implications for reconstructing past tropical/subtropical surface water conditions: Geochemistry, Geophysics, Geosystems, v. 6, Q11005, doi:10.1029/2005GC000926.

STREETER, S. S., 1973, Bottom water and benthonic foraminifera in the North Atlantic-glacial-interglacial contrasts: Quaternary Research, v. 3, p. 131-141.

- 2 , and Shackelton, N. J., 1979, Paleocirculation of the deep North Atlantic: 150,000-year record of benthic foraminifera and oxygen-18: Science, v. 203, p. 168-171.

Sugarman, P. J., Miller, K. G., Owens, J. P., and Feigenson, M. D., 1993, Strontium-isotope and sequence stratigraphy of the Miocene Kirkwood Formation, southern New Jersey: Geological Society of America Bulletin, v. 105, p. 423-436.

Thomas, E., and Gooday, A. J., 1996, Deep-sea benthic foraminifera: tracers for changes in Cenozoic oceanic productivity: Geology, v. 24 , p. 355-358.

, and Vincent, E., 1987, Equatorial Pacific deep-sea benthic foraminifera: faunal changes before the middle Miocene polar cooling: Geology, v. 15, p. 1035-1039.

Thunell, R. C., and BelyeA, P., 1982, Neogene planktonic foraminiferal biogeography of the Atlantic Ocean: Micropaleontology, v. 28, p. 381-398.

, and ReYNolds, L. A., 1984, Sedimentation of planktonic foraminifera: seasonal changes in species flux in the Panama basin: Micropaleontology, v. 30, p. 241-260.

Toggweiler, J. R., 2008, Origin of the 100,000-yr time scale in Antarctic temperatures and atmospheric $\mathrm{CO}_{2}$ : Paleoceanography, v. 23, PA2211, doi:10.1029/2006PA001405.

UREY, H. C., 1947, The thermodynamic properties of isotopic substances: Journal of the Chemical Society, p. 562-581.

van der ZwaAn, G. J., Duijnstee, I. A. P., Den Dulk, M., Ernst, S. R., Jannink, N. T., and Kouwenhoven, T. J., 1999, Benthic foraminifers: proxies or problems? A review of paleoecological concepts: Earth-Science Reviews, v. 46, p. 213-236.

VAnce, D., and Burton, K., 1999, Neodymium isotopes in planktonic foraminifera: a record of the response of continental weathering and ocean circulation rates to climate change: Earth and Planetary Science Letters, v. 173, p. 365-379.

- Scrivner, A. E., Beney, P., Staubwasser, M., Henderson, G. M., and Slowey, N. C., 2004, The use of foraminifera as a record of the past neodymium isotope composition of seawater: Paleoceanography, v. 19, PA2009, doi:10.1029/2003PA000957.

Vincent, E., and Berger, W. H., 1985, Carbon dioxide and polar cooling in the Miocene: The Monterey Hypothesis, in Sundquist, E. T., and Broecker, W. S. (eds.), The Carbon Cycle and Atmospheric $\mathrm{CO}_{2}$ : Natural Variations Archean to Present, v. 32: American Geophysical Union, Washington, D.C., p. 455-468.

VON Blanckenburg, F., 1999, Perspectives: Paleoceanography tracing past ocean circulation?: Science, v. 286, p. 1862-1863.

von Langen, P. J., PAK, D. K., Spero, H. J., and Lea, D. W., 2005, Effects of temperature on $\mathrm{Mg} / \mathrm{Ca}$ in neogloboquadrinid shells 
determined by live culturing: Geochemistry, Geophysics, Geosystems, v. 6, 11, doi:10.1029/2005GC000989.

WALlmanN, K., 2004, Impact of atmospheric $\mathrm{CO}_{2}$ and galactic cosmic radiation on Phanerozoic climate change and the marine $\delta^{18} \mathrm{O}$ record: Geochemistry, Geophysics, Geosystems, v. 5, Q06004, doi: 10.1029/2003GC000683.

Weldeab, S., Lea, D. W., Schneider, R. R., and Andersen, N., 2007, 155,000 years of West African monsoon and ocean thermal evolution: Science, v. 316, p. 303-309.

Woodruff, F., and SAvin, S. M., 1991, Mid-Miocene isotope stratigraphy in the deep sea: high resolution correlations, paleoclimatic cycles, and sediment preservation: Paleoceanography, v. 6 , p. $755-806$.

Wright, J. D., 2001, Cenozoic climate - oxygen isotope evidence, in Steele, J., Thorpe, S., and Turekian, K. (eds.), Encyclopedia of Ocean Sciences: Academic Press, London, p. 415-426.

, and Miller, K. G., 1996, Control of North Atlantic Deep Water circulation by the Greenland-Scotland Ridge: Paleoceanography, v. 11, p. 157-170.

, and Thunell, R. C., 1988, Neogene planktonic foraminiferal biogeography and paleoceanography of the Indian Ocean: Micropaleontology, v. 34, p. 193-216.

-, Miller, K. G., and Fairbanks, R. G., 1991, Evolution of modern deepwater circulation: evidence from the late Miocene Southern Ocean: Paleoceanography, v. 6, p. 275-290.

Yu, J., and Elderfield, H., 2007, Benthic foraminiferal B/Ca ratios reflect deep water carbonate saturation state: Earth and Planetary Science Letters, v. 258, p. 73-86. and $-2008, \mathrm{Mg} / \mathrm{Ca}$ in the benthic foraminifera Cibicidoides wuellerstorfi and Cibicidoides mundulus: temperature versus carbonate ion saturation: Earth and Planetary Science Letters, v. 276, p. 129-139.

- - , and HöNISCH, B., 2007, B/Ca in planktonic foraminifera as a proxy for surface seawater $\mathrm{pH}$ : Paleoceanography, v. 22, PA2202, doi:2210.1029/2006PA001347.

Zachos, J. C., Shackleton, N., Revenaugh, J., Pälike, H., and Flower, B., 2001a, Climate response to orbital forcing across the Oligocene-Miocene boundary: Science, v. 292, p. 274-278.

Pagani, M., Sloan, L., Thomas, E., and Billups, K., 2001b, Trends, rhythms, and aberrations in global climate change $65 \mathrm{Ma}$ to present: Science, v. 292, p. 686-693.

Zeebe, R. E., and Wolf-Gladrow, D. A., 2001, $\mathrm{CO}_{2}$ in Seawater: Equilibrium, Kinetics, Isotopes: Elsevier Oceanography Series, Amsterdam, v. 65 , p. 346

_- Bijma, J., and Wolf-Gladrow, D. A., 1999, A diffusionreaction model of carbon isotope fractionation in foraminifera: Marine Chemistry, v. 64, p. 199-227.

- — BIJMA, J., and HöNISCH, B., 2003, Vital effects in foraminifera do not compromise the use of $\delta^{11} \mathrm{~B}$ as a paleo-pH indicator: evidence from modeling: Paleoceanography, v. 18, 1043, doi:10.1029/2003PA000881.

Received 11 May 2009 Accepted 15 September 2009 